\title{
Green Power Marketing in the United States: A Status Report (Tenth Edition)
}

Technical Report NREL/TP-670-42502

December 2007

Lori Bird, Leila Dagher, and Blair Swezey 


\section{Green Power Marketing in the United States: A Status Report (Tenth Edition)}

Lori Bird, Leila Dagher, and Blair Swezey

Prepared under Task No. IGST.7330
Technical Report NREL/TP-670-42502

December 2007

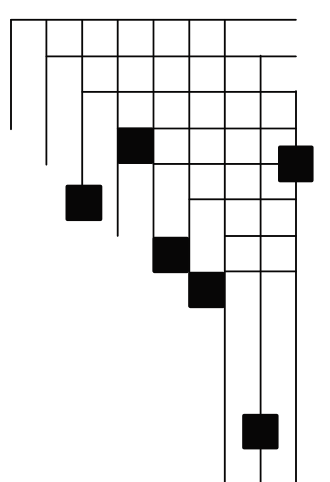




\section{NOTICE}

This report was prepared as an account of work sponsored by an agency of the United States government. Neither the United States government nor any agency thereof, nor any of their employees, makes any warranty, express or implied, or assumes any legal liability or responsibility for the accuracy, completeness, or usefulness of any information, apparatus, product, or process disclosed, or represents that its use would not infringe privately owned rights. Reference herein to any specific commercial product, process, or service by trade name, trademark, manufacturer, or otherwise does not necessarily constitute or imply its endorsement, recommendation, or favoring by the United States government or any agency thereof. The views and opinions of authors expressed herein do not necessarily state or reflect those of the United States government or any agency thereof.

Available electronically at http://www.osti.gov/bridge

Available for a processing fee to U.S. Department of Energy and its contractors, in paper, from:

U.S. Department of Energy

Office of Scientific and Technical Information

P.O. Box 62

Oak Ridge, TN 37831-0062

phone: 865.576 .8401

fax: 865.576 .5728

email: mailto:reports@adonis.osti.gov

Available for sale to the public, in paper, from:

U.S. Department of Commerce

National Technical Information Service

5285 Port Royal Road

Springfield, VA 22161

phone: 800.553.6847

fax: 703.605.6900

email: orders@ntis.fedworld.gov

online ordering: http://www.ntis.gov/ordering.htm 


\section{Acknowledgments}

This work was funded by the U.S. Department of Energy's (DOE) Office of Energy Efficiency and Renewable Energy (EERE). The authors wish to thank Linda Silverman, John Atcheson, and the EERE renewable energy technology programs for their support of this work. The authors also wish to thank Gabe Petlin of 3Degrees Inc., Alex Pennock of the Center for Resource Solutions, Ed Holt of Ed Holt \& Associates, and Karlynn Cory and Gian Porro of NREL their thoughtful review of the document, as well as Jennifer Josey of NREL for her editorial support and Marshall Kaiser for his research support. We would also like to recognize Blair Swezey, formerly of NREL and now with Applied Materials in Santa Clara, California for his contribution to this report, his mentorship, as well as his many years of work on green power markets. Finally, the authors thank the many green power marketers and utility contacts that provided the information summarized in this report. Additional information on green power market trends and activities can be found on the U.S. DOE's Green Power Network Web site (http://www.eere.energy.gov/greenpower/). 


\section{Table of Contents}

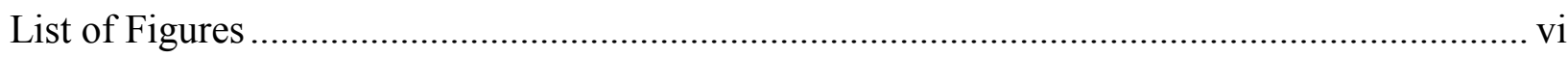

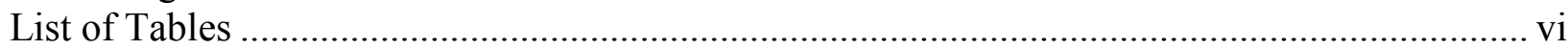

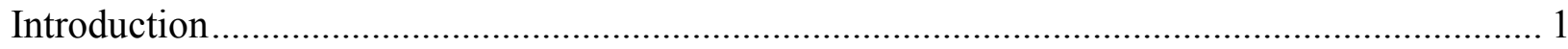

Green Power Market Summary and Trends........................................................................ 3

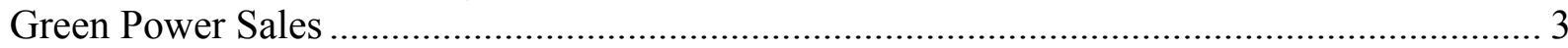

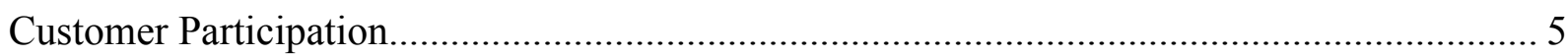

Utility Green Pricing Programs …………………………........................................... 7

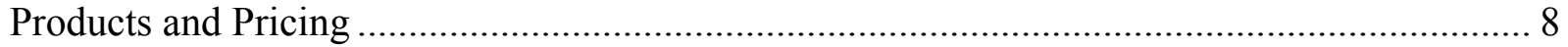

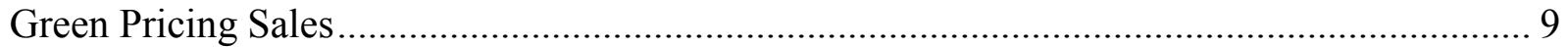

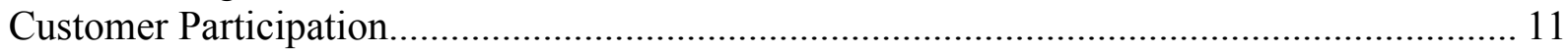

Competitive Green Power and REC Markets ……………................................................... 13

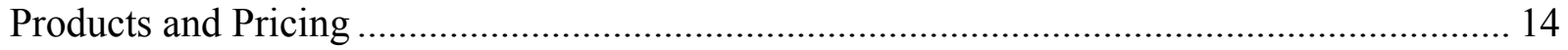

Customer Participation.................................................................................................. 16

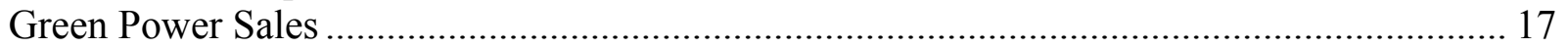

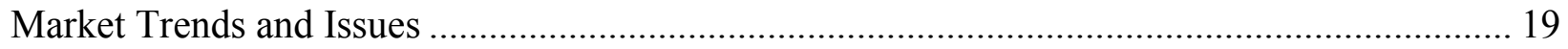

Influence of Renewable Portfolio Standards on Green Power Markets ................................. 19

Supply and Demand Balance of Renewable Electricity ........................................................ 22

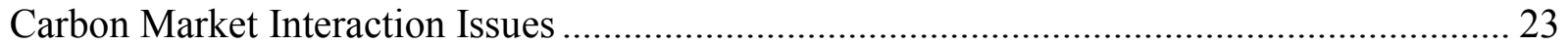

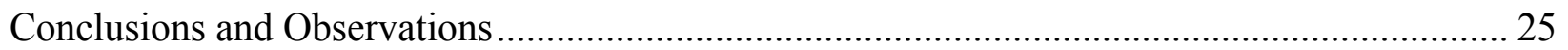

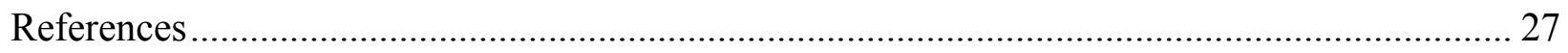

Appendix A - Estimates of Renewable Energy Capacity Serving Gree Power Markets, 2000-

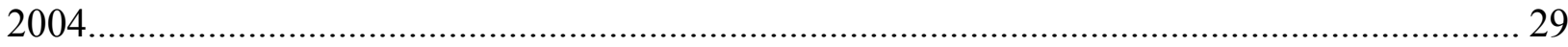

Appendix B - Top 25 Purchasers in the U.S. EPA Green Power Partnership, September 2007 . 30 Appendix C - Estimated U.S. Green Pricing Customers by State and Customer Class, 2004 and 2005 31

Appendix D - Utilities Offering Green Pricing Programs in Regulated Markets, 2006 ............... 33

Appendix E - Utility Green Pricing Programs, September 2007 ……....................................... 35

Appendix F - State-Specific Retail Green Power Product Offerings in Competitive Electricity

Markets, October 2007........................................................................................................ 55

Appendix G - Renewable Energy Certificate Retail Products, October 2007 ............................. 59 


\section{List of Figures}

Figure 1. States with green power programs ............................................................... 2

Figure 2. Estimated green power sales by renewable energy source, 2006.............................. 3

Figure 3. Utility green pricing activities ................................................................... 7

Figure 4. Trend in utility green pricing premiums, 2000-2006 ........................................ 9

Figure 5. Annual sales of green energy through utility green pricing programs (regulated

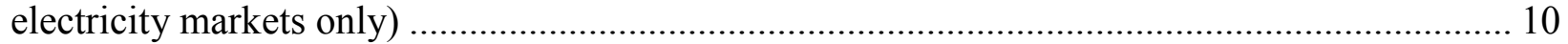

Figure 6. Green power marketing activity in competitive electricity markets ......................... 14

Figure 7. Voluntary green power sales in selected states with RPS ...................................... 20

Figure 8. Voluntary green power purchases through utility programs in states with RPS.......... 21

Figure 9. Estimated and projected supply and demand for renewable electricity ..................... 23

\section{List of Tables}

Table 1. Estimated Green Power Sales by Market Sector, 2003-2006 .................................... 4

Table 2. Estimated Annual Green Power Sales by Customer Segment, 2004-2006 ................... 4

Table 3. Estimated Green Power Sales by Customer Segment and Market Sector, 2006 ............. 5

Table 4. Estimated Renewable Energy Capacity Supplying Green Power Markets, 2005-2006 ... 5

Table 5. Estimated Cummulative Green Power Customers by Market Segment, 2000-2005....... 6

Table 6. Price Premiums of Utility Green Power Products ...................................................... 8

Table 7. Annual Sales of Green Energy through Utility Green Pricing Programs (Regulated

Electricity Markets Only) ..................................................................................................... 9

Table 8. Renewable Energy Generation and Capacity Supplying Green Pricing Programs, 2006

Table 9. Estimated Cummulative Number of Customers Participating in Utility Green Pricing

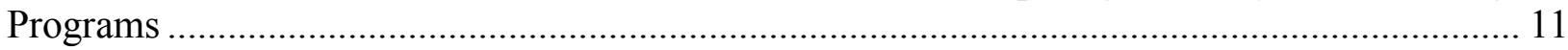

Table 10. Customer Participation Rates in Utility Green Pricing Programs ............................. 12

Table 11. Total Sales of Green-e Certified Renewable Energy, 2006.................... 15

Table 12. Estimated Cummulative Number of Customers Purchasing RECs or Green Power from Competitive Marketers, 2002-2006 .................................................................................. 16

Table 13. Retail Sales of Renewable Energy in Competitive Markets and RECs..................... 17

Table 14. Renewable Energy Sources Supplying Competitive and REC Markets, 2006........... 18

Table A-1. Estimated Cummulative "New" Renewable Energy Capacity Supplying Green Power

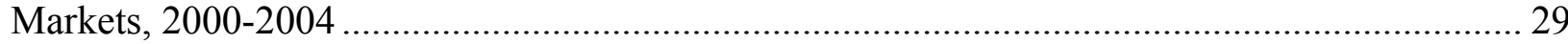

Table B-1. Top 25 Purchasers in the U.S. EPA Green Power Partnership, September 2007 ...... 30 Table C-1. Estimated U.S. Green Pricing Customers by State and Customer Class, 2004 and

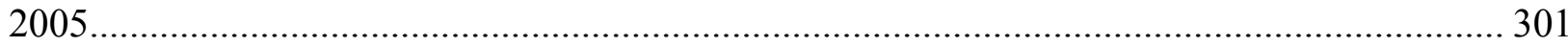

Table C-2. Estimated U.S. Green Pricing Customers by Customer Class, 2002-006.......... 32

Table D-1. Utilities Offering Green Pricing Programs in Regulated Markets, 2006 ................ 333

Table D-2. Utility/Marketer Green Power Programs in Restructured Electricity Markets, 200534

Table E-1. Table of Utility Green Pricing Programs, September 2007 ................................ 355

Table F-1. State-Specific Retail Green Power Product Offerings in Competitive Electricity

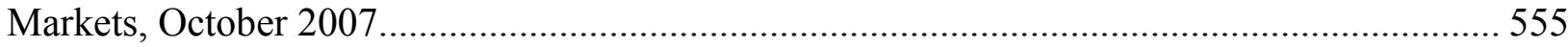

Table G-1. Renewable Energy Certificate Retail Products, October 2007............................. 599 


\section{Introduction}

Voluntary consumer decisions to purchase electricity supplied from renewable energy sources represent a powerful market support mechanism for renewable energy development. Beginning in the early 1990s, a small number of U.S. utilities began offering "green power" options to their customers. ${ }^{1}$ Since then, these products have become more prevalent, both from traditional utilities and from marketers operating in states that have introduced competition into their retail electricity markets. Today, more than half of all U.S. electricity customers have an option to purchase some type of green power product from a retail electricity provider.

Currently, more than 750 utilities, or about $25 \%$ of utilities nationally, offer green power programs to customers. These programs allow customers to purchase some portion of their power supply as renewable energy — almost always at a higher price — or to contribute funds for the utility to invest in renewable energy development. The term "green pricing" is typically used to refer to these utility programs offered in regulated or noncompetitive electricity markets.

In states with competitive (or restructured) retail electricity markets, electricity customers can often purchase electricity generated from renewable sources by switching to an alternative electricity supplier that offers green power. In some of these states, default utility electricity suppliers offer green power options to their customers in conjunction with competitive green power marketers. $^{2}$ To date, nearly a dozen states that have opened their markets to retail competition have experienced some green power marketing activity. Through the combination of utility green pricing and competitive retail markets, green power is available to most electricity customers living in 46 out of the 50 U.S. states (Figure 1).

Finally, regardless of whether they have access to a green power product from their retail power provider, any consumer can purchase green power through renewable energy certificates (RECs), which represent the "attributes" of electricity generated from renewable energy-based projects. Consumers in competitive markets can also support renewable energy development through REC purchases without having to switch to an alternative electricity supplier. Today, several dozen companies actively market RECs to residential or business customers throughout the United States.

This report documents green power marketing activities and trends in the United States. First, we present aggregate green power sales data for all voluntary purchase markets across the United States. The next two sections provide summary data on 1) utility green pricing programs offered in regulated electricity markets and 2) green power marketing activity in competitive electricity markets as well as green power sold to voluntary purchasers in the form of RECs. These are followed by a discussion of key market trends and issues. The final section offers conclusions

\footnotetext{
${ }^{1}$ The term "green power" generally refers to electricity supplied in whole or in part from renewable energy sources, such as wind and solar power, geothermal, hydropower, and various forms of biomass.

${ }^{2}$ Under these programs, consumers can purchase renewable energy from independent renewable energy marketing companies without switching their electricity service from the default or standard offer service provider.
} 
and observations. The data presented in this report are based on figures provided to NREL by utilities and independent renewable energy marketers. $^{3}$

\section{States with Green Power Programs}

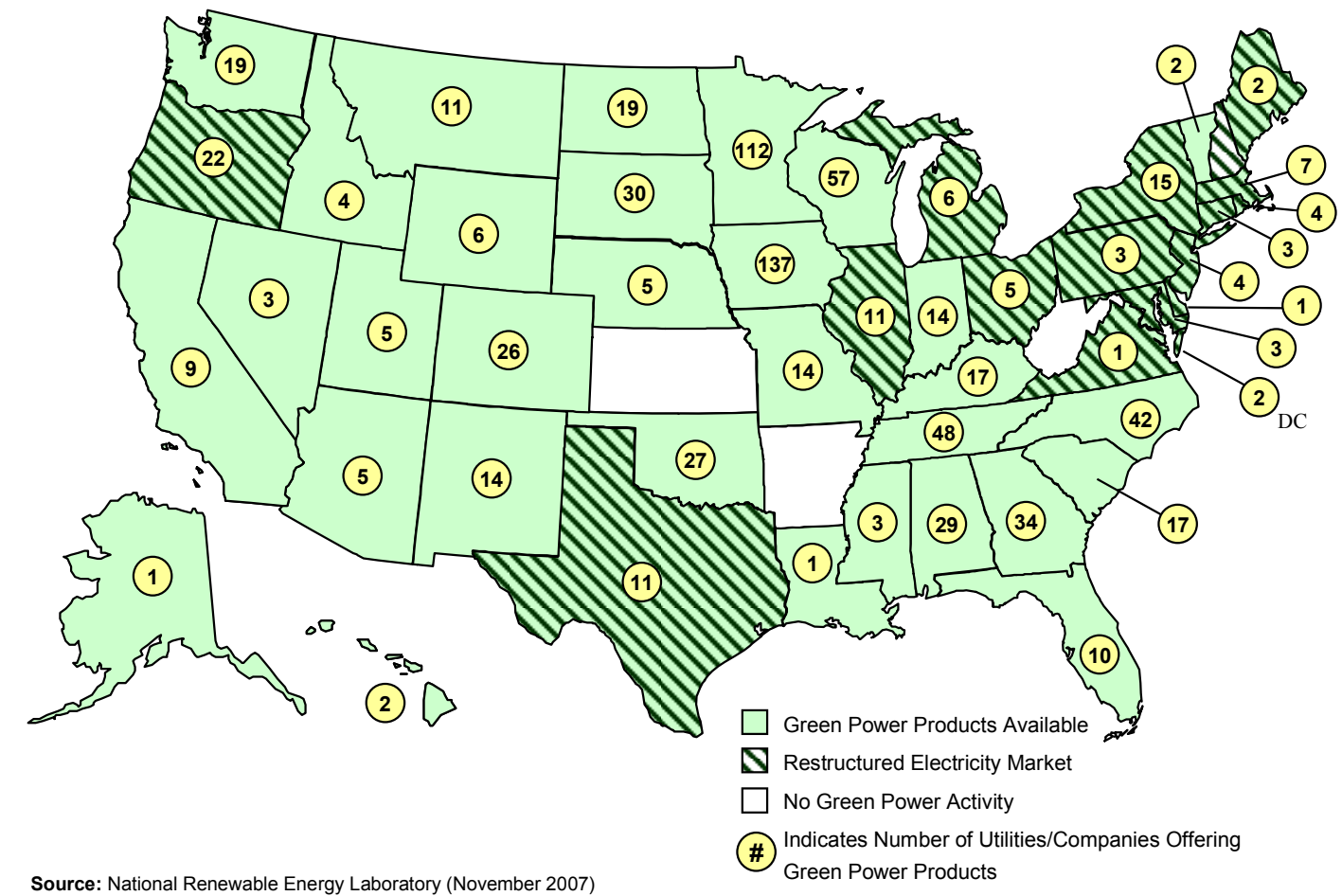

Figure 1. States with green power programs

\footnotetext{
${ }^{3}$ Green power market data for previous years are available in Bird and Swezey (2006), Bird and Swezey (2005a),
} Bird and Swezey (2004), Bird and Swezey (2003), Swezey and Bird (2000), Swezey and Bird (1999). 


\section{Green Power Market Summary and Trends}

\section{Green Power Sales}

Overall, retail sales of renewable energy in voluntary purchase markets totaled about 12 billion kilowatt-hours (kWh) in 2006 , or about $0.3 \%$ of total U.S. electricity sales. ${ }^{4}$ This includes sales of renewable energy derived from both "new" and "existing" renewable energy sources, with most sales supplied from new sources. ${ }^{5}$ Wind energy provided $62 \%$ of green power sales, followed by biomass energy sources, including landfill gas (23\%), geothermal (7\%), hydropower $(6 \%)$, and solar (1\%) (Figure 2). Based on the sales data presented in this report, we estimate the market value of green power sales in 2006 to be from $\$ 65$ million to $\$ 85$ million.

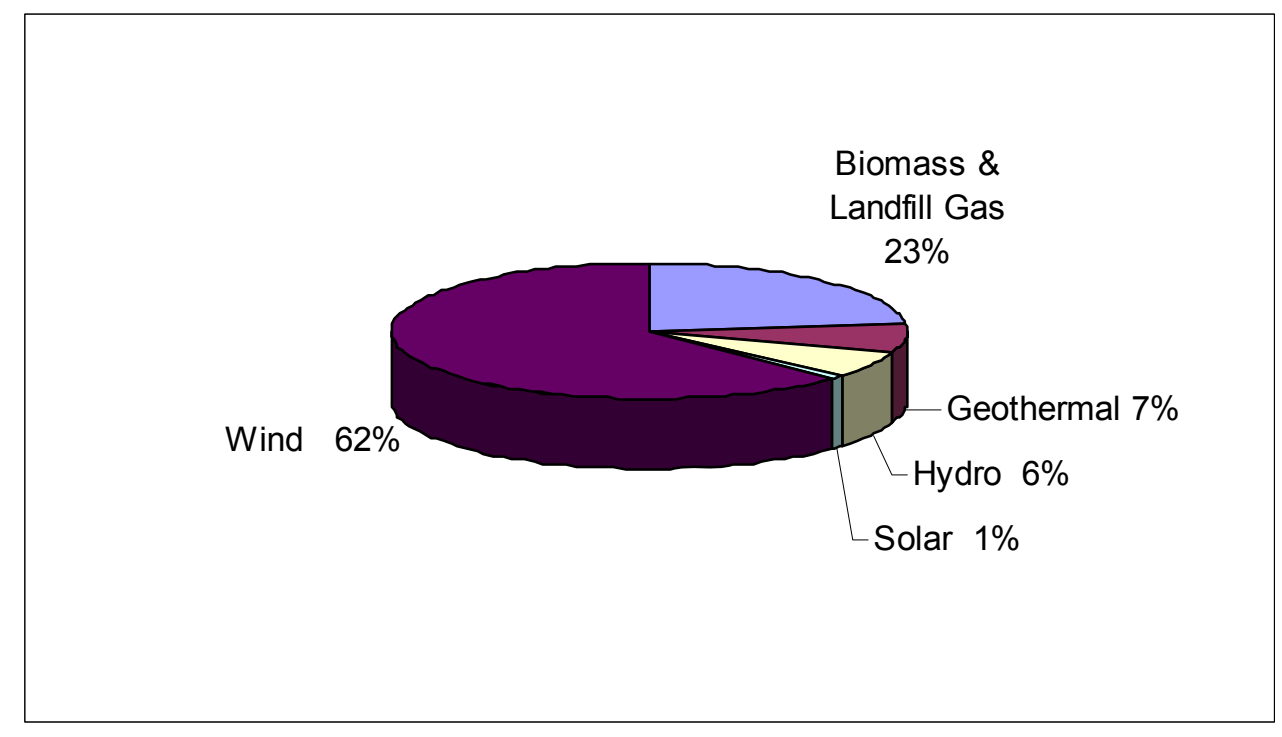

Figure 2. Estimated green power sales by renewable energy source, 2006

Green power sales increased by about $40 \%$ by volume in 2006 , with annual growth rates averaging $46 \%$ since 2003 (Table 1). REC sales have been driving much of the growth, increasing $75 \%$ in 2006 , after more than doubling in 2005 . Sales through utility green pricing programs also exhibited strong annual growth of nearly $40 \% .{ }^{6}$ However, sales in competitive

\footnotetext{
${ }^{4}$ U.S. electricity sales totaled 3,670 billion $\mathrm{kWh}$ in 2006, according to the U.S. Energy Information Administration

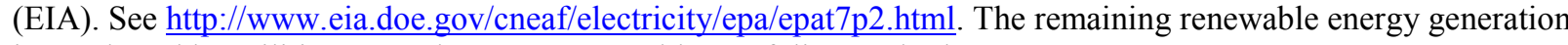
is rate-based by utilities or used to meet renewable portfolio standards.

${ }^{5}$ With green power, a distinction is often made based on the vintage of the renewable energy generator. The green power industry generally follows the Green-e national standard, which defines a "new" renewable generation facility as one placed in operation or repowered on or after January 1, 1997. An "existing" generation facility, therefore, is one placed in service before January 1, 1997. For more information on the Green-e national standard, see http://www.green-e.org/ipp/national_standard.html.

${ }^{6}$ The REC sales figures reflect sales to end use customers separate from electricity. RECs bundled with electricity and sold to end-use customers through utility green pricing programs or in competitive electricity markets are counted in these other categories.
} 
markets fell by $20 \%$, because rising costs associated with supplying customers with renewable electricity service caused some marketers to lose or turn back customers to default service (see the competitive markets discussion). REC markets now represent more than half of industry sales, replacing competitive markets as the dominant market sector.

Sales to nonresidential customers continued to outpace those to residential consumers, with nearly three-quarters of all sales by volume to the nonresidential sector in 2006 (Table 2).

Although renewable energy sales to residential customers through utility green pricing programs increased by about $30 \%$ in 2006 , losses in some competitive markets, such as Pennsylvania, led to a modest overall increase in residential sales. Nearly all REC sales were to nonresidential customers, while residential customers played a larger role in green pricing programs and competitive markets, where they accounted for nearly $60 \%$ of renewable energy sales (Table 3 ).

Table 1. Estimated Annual Green Power Sales by Market Sector, 2003-2006* (millions of $\mathbf{k W h}$ )

\begin{tabular}{|l|c|c|c|c|c|c|c|}
\hline Market Sector & $\mathbf{2 0 0 3}$ & $\mathbf{2 0 0 4}$ & $\mathbf{2 0 0 5}$ & $\mathbf{2 0 0 6}$ & $\begin{array}{c}\mathbf{\%} \text { Change } \\
\mathbf{2 0 0 3 / 2 0 0 4}\end{array}$ & $\begin{array}{c}\mathbf{\%} \text { Change } \\
\mathbf{2 0 0 4 / 2 0 0 5}\end{array}$ & $\begin{array}{c}\mathbf{\%} \text { Change } \\
\mathbf{2 0 0 5 / 2 0 0 6}\end{array}$ \\
\hline $\begin{array}{l}\text { Utility Green } \\
\text { Pricing }\end{array}$ & 1,300 & 1,800 & 2,500 & 3,400 & $44 \%$ & $33 \%$ & $39 \%$ \\
\hline $\begin{array}{l}\text { Competitive } \\
\text { Markets }\end{array}$ & 1,900 & 2,700 & 2,200 & 1,700 & $39 \%$ & $-19 \%$ & $-20 \%$ \\
\hline REC Markets & 660 & 1,700 & 3,900 & 6,800 & $161 \%$ & $126 \%$ & $75 \%$ \\
\hline Retail Total & $\mathbf{3 , 8 0 0}$ & $\mathbf{6 , 2 0 0}$ & $\mathbf{8 , 5 0 0}$ & $\mathbf{1 1 , 9 0 0}$ & $\mathbf{6 2 \%}$ & $\mathbf{3 7 \%}$ & $\mathbf{4 1 \%}$ \\
\hline
\end{tabular}

*Includes sales of new and existing renewable energy. Totals and growth rates may not calculate due to rounding.

${ }^{* *}$ Includes only RECs sold to end-use customers separate from electricity. RECs are often purchased wholesale to supply utility and competitively marketed products and bundled with electricity. RECs bundled with electricity are included in utility green pricing and competitive market sales estimates.

Table 2. Estimated Annual Green Power Sales by Customer Segment, 2004-2006* (millions of kWh)

\begin{tabular}{|c|c|c|c|c|c|}
\hline Customer Segment & $\mathbf{2 0 0 4}$ & $\mathbf{2 0 0 5}$ & $\mathbf{2 0 0 6}$ & $\begin{array}{c}\mathbf{\%} \text { Change } \\
\mathbf{2 0 0 4 / 2 0 0 5}\end{array}$ & $\begin{array}{c}\mathbf{\%} \text { Change } \\
\mathbf{2 0 0 5 / 2 0 0 6}\end{array}$ \\
\hline Residential & 3,500 & 3,000 & 3,200 & $-14 \%$ & $8 \%$ \\
\hline Nonresidential & 2,700 & 5,500 & 8,700 & $101 \%$ & $58 \%$ \\
\hline Total & $\mathbf{6 , 2 0 0}$ & $\mathbf{8 , 5 0 0}$ & $\mathbf{1 1 , 9 0 0}$ & $\mathbf{3 7 \%}$ & $\mathbf{4 1 \%}$ \\
\hline$\%$ Nonresidential & $44 \%$ & $65 \%$ & $73 \%$ & -- & \\
\hline
\end{tabular}

At the end of 2006, kWh-sales of renewable energy in voluntary markets represented a generating capacity equivalent of about 3,500 MW, with about 3,100 MW of that from "new" renewable energy sources (Table 4). Since 2000, the amount of renewable energy capacity serving green power markets has increased nearly 20-fold (see Appendix A). 
Table 3. Estimated Annual Green Power Sales by Customer Segment and Market Sector, 2006 (millions of $\mathbf{k W h}$ )

\begin{tabular}{|l|c|c|c|c|}
\hline Customer Segment & $\begin{array}{c}\text { Green } \\
\text { Pricing }\end{array}$ & $\begin{array}{c}\text { Competitive } \\
\text { Markets }\end{array}$ & $\begin{array}{c}\text { REC } \\
\text { Markets }\end{array}$ & Total \\
\hline Residential & 2,100 & 1,000 & 100 & 3,200 \\
\hline Nonresidential & 1,300 & 700 & 6,700 & 8,700 \\
\hline Total & $\mathbf{3 , 4 0 0}$ & $\mathbf{1 , 7 0 0}$ & $\mathbf{6 , 8 0 0}$ & $\mathbf{1 1 , 9 0 0}$ \\
\hline$\%$ Residential & $62 \%$ & $58 \%$ & $2 \%$ & $27 \%$ \\
\hline
\end{tabular}

Note: Totals may not add due to rounding.

Table 4. Estimated Cumulative Renewable Energy Capacity Supplying Green Power Markets, 2005-2006 (megawatts)

\begin{tabular}{|c|c|c|c|c|}
\hline Market & $\begin{array}{c}2005 \\
\text { Total } \\
\text { Renewables } \\
\text { Capacity } \\
\end{array}$ & $\begin{array}{c}2005 \text { "New" } \\
\text { Renewables } \\
\text { Capacity }\end{array}$ & $\begin{array}{c}2006 \\
\text { Total } \\
\text { Renewables } \\
\text { Capacity } \\
\end{array}$ & $\begin{array}{c}2006 \text { "New" } \\
\text { Renewables } \\
\text { Capacity }\end{array}$ \\
\hline Utility Green Pricing & 800 & 700 & 1,100 & 1,000 \\
\hline $\begin{array}{l}\text { Competitive } \\
\text { Markets/RECs }\end{array}$ & 1,700 & 1,300 & 2,400 & 2,100 \\
\hline Total & 2,500 & 2,000 & 3,500 & 3,100 \\
\hline
\end{tabular}

Note: "New" renewables capacity is a subset of total renewables capacity supplying green power markets.

Based on data from EIA, NREL estimates that about 10,650 MW of "new" renewable energy capacity was installed in the United States between 1997 and the end of 2006; thus, voluntary green power markets provide support for nearly $30 \%$ of "new" renewable energy capacity additions nationally. ${ }^{7}$ Much of the remaining renewable energy generation from recent capacity additions is used for compliance with state renewable portfolio standards or other policy mandates, separate from voluntary green power markets.

\section{Customer Participation}

In 2006, an estimated 700,000 electricity customers nationally purchased green power products through regulated utility companies, from green power marketers in a competitive market setting, or in the form of RECs (Table 5). ${ }^{8}$ In aggregate, utility green pricing programs have shown

\footnotetext{
${ }^{7}$ Based on data from EIA, NREL estimates that $10,650 \mathrm{MW}$ of new renewable energy capacity (excluding large hydropower) came online from 1997 through 2006. The methodology for calculating new renewable energy supply is presented in Swezey et al. 2007 http://www.eere.energy.gov/greenpower/pdfs/42266.pdf.

${ }^{8}$ It is important to note that there is greater uncertainty in our customer estimates for competitive and REC markets because of data limitations. For more detailed estimates by state for 2004 and 2005, see data from U.S. EIA 2007 in Appendix C. Generally, our estimates are consistent with the EIA estimates when adjusted for customers in Ohio who participate in community aggregations. We exclude these customers from our estimates because they purchase products with very low renewable energy content ( $1 \%$ to $2 \%)$.
} 
steady growth in customers over time as the number of utility programs has increased and as existing programs have grown. On the other hand, competitive markets have been less consistent. While green power sales have grown in Texas and some Northeast states, other markets have failed - notably in California, Connecticut, and most recently, Pennsylvania. While REC customers represent a small fraction of the total customer base, REC sales represent more than half of all green power sales and have grown dramatically in recent years as a result of a number of very large purchases (see Appendix B for a list of top green power purchasers).

Table 5. Estimated Cumulative Green Power Customers by Market Segment, 2000-2005

\begin{tabular}{|c|c|c|c|c|c|c|c|}
\hline & 2000 & 2001 & 2002 & 2003 & 2004 & 2005 & 2006 \\
\hline $\begin{array}{l}\text { Utility Green } \\
\text { Pricing }\end{array}$ & 130,000 & 170,000 & 230,000 & 270,000 & 330,000 & 390,000 & 490,000 \\
\hline $\begin{array}{l}\text { Competitive } \\
\text { Markets }\end{array}$ & $>160,000$ & $>110,000$ & $\sim 150,000$ & $>170,000$ & $>140,000$ & $>180,000$ & $\sim 210,000$ \\
\hline REC Markets* & -- & -- & $<10,000$ & $<10,000$ & $<10,000$ & $<10,000$ & $\sim 10,000$ \\
\hline Retail Total & $>290,000$ & $>280,000$ & $\sim 390,000$ & $\sim 450,000$ & $\sim 480,000$ & $\sim 580,000$ & $\sim 710,000$ \\
\hline$\%$ Change & $n / a$ & $\sim-3 \%$ & $\sim 39 \%$ & $\sim 15 \%$ & $\sim 7 \%$ & $\sim 21 \%$ & $\sim 22 \%$ \\
\hline
\end{tabular}

Note: In some cases, estimates have been revised from those reported in previous NREL reports as updated data have become available.

*Includes only end-use customers purchasing RECs separate from electricity.

Average participation rates among utility green pricing programs increased slightly to $1.8 \%$ in 2006 , with a median value of $1.0 \%$; top performing programs have achieved rates ranging from $5 \%$ to $17 \%$. Competitive markets have experienced green power customer penetration rates ranging from $1 \%$ to $2 \%$ in states where the market has been conducive to retail competition. 


\section{Utility Green Pricing Programs}

The number of utilities offering green pricing has grown steadily in recent years- today, more than 750 investor-owned, public, and cooperative utilities in 38 states offer green pricing programs (Figure 3). Appendix D provides a list of utilities offering green pricing while Appendix E provides detailed program information. ${ }^{9}$ Because a number of small municipal or cooperative utilities offer programs developed by their power suppliers, the number of distinct green pricing programs is about 150 . Initially, some portion of the growth in utility green power offerings was attributable to the threat of retail market competition, while more recent growth has been spurred by state laws requiring utilities to offer green pricing. ${ }^{10}$ In addition, a number of utilities have expanded their programs as customer demand has grown.

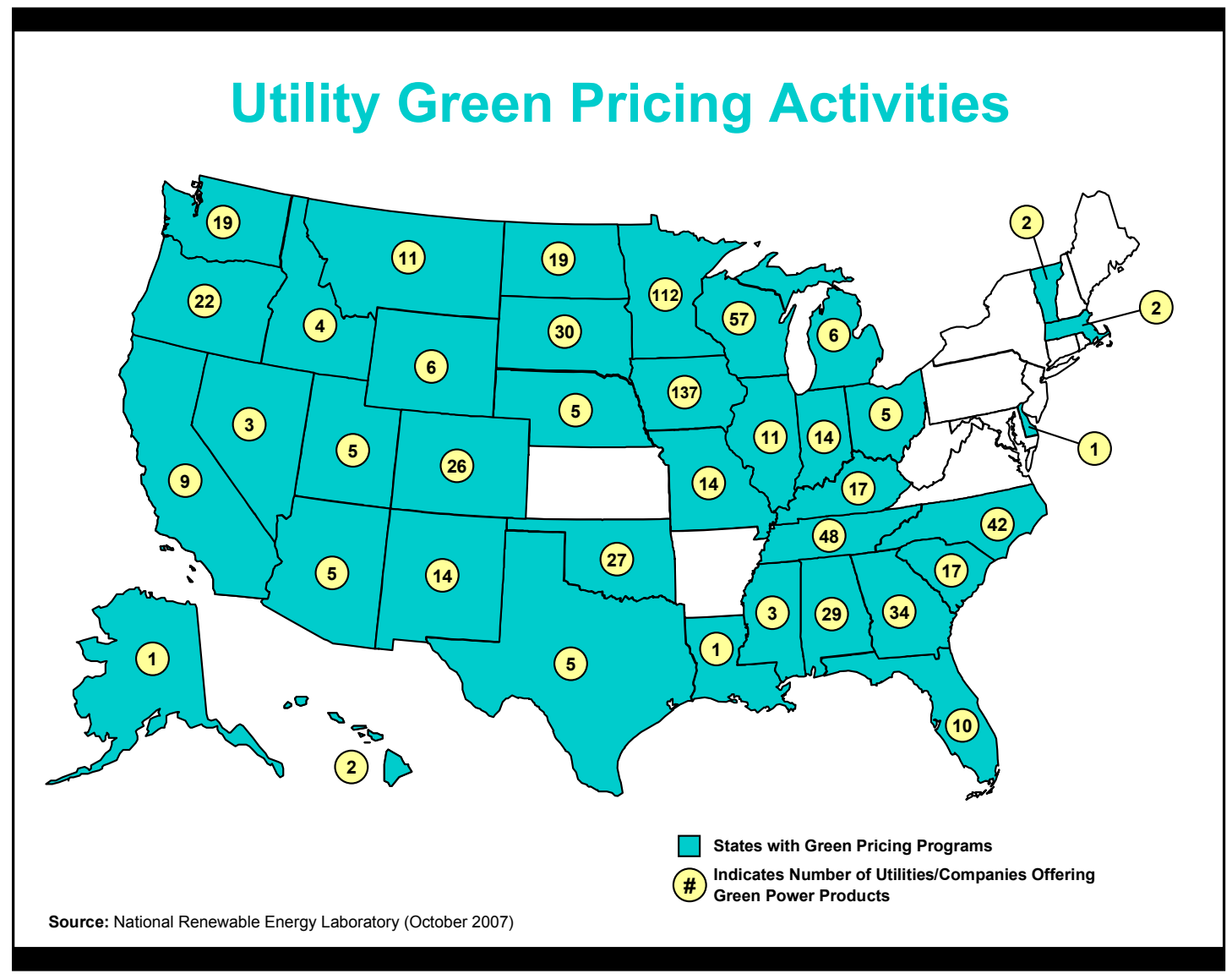

Figure 3. Utility green pricing activities

\footnotetext{
${ }^{9}$ For an up-to-date list of utilities with green pricing programs, see the U.S. Department of Energy's Green Power Network Web site at http://www.eere.energy.gov/greenpower/markets/pricing.shtml?page=1.

${ }^{10}$ These states include Iowa, Minnesota, Montana, New Mexico, Oregon, and Washington.
} 


\section{Products and Pricing}

Typically, green pricing programs are structured so that customers can either purchase green power for a certain percentage of their electricity use (often called "percent-of-use products") or in discrete amounts or blocks at a fixed price ("block products"), such as a 100-kWh block. Most utilities offer block products but may also allow customers to purchase green power for their entire monthly electricity use. Utilities that offer percent-of-use products generally allow residential customers to elect to purchase $25 \%, 50 \%$, or $100 \%$ of their electricity use as renewable energy, while a few offer fractions as small as $10 \%$. Under these types of programs, larger purchasers, such as businesses, can often purchase green power for a smaller fraction of their electricity use.

In 2006, price differentials for energy-based programs ranged from $-0.13 \phi / \mathrm{kWh}$ (a discount) to $17.6 \phi / \mathrm{kWh}$, with an average premium of $2.1 \phi / \mathrm{kWh}$ and a median of $1.8 \phi / \mathrm{kWh}$ (Table 6 ). These premiums have been adjusted to account for any fuel cost exemptions granted to green power program participants. ${ }^{11}$ Programs that feature solar-based products represent the high end of the range.

Since 2000, the average price premium has dropped at an average annual rate of $8 \%$ (Figure 4). Some of this reduction can be attributed to lower market costs for renewable energy supplies. Increases in the price of natural gas have narrowed the price gap between renewables and gasfired generation alternatives, leading to lower initial premiums for many new programs; however, they have also reduced the effective premiums in programs that exempt participating customers from fuel-related price increases. In addition, a number of utilities have lowered their premiums over time to reflect changing market conditions. Despite the downward trend in premiums, installation costs are increasing for new renewable energy facilities, largely as a result of rising commodity prices, which may affect premiums in coming years.

Table 6. Price Premiums of Utility Green Power Products ( $\phi / k W h)$

\begin{tabular}{|l|c|c|c|c|c|c|c|}
\hline & $\mathbf{2 0 0 0}$ & $\mathbf{2 0 0 1}$ & $\mathbf{2 0 0 2}$ & $\mathbf{2 0 0 3}$ & $\mathbf{2 0 0 4}$ & $\mathbf{2 0 0 5}$ & $\mathbf{2 0 0 6}$ \\
\hline Average Premium & 3.48 & 2.93 & 2.82 & 2.62 & 2.45 & 2.36 & 2.12 \\
\hline Median Premium & 2.50 & 2.50 & 2.50 & 2.00 & 2.00 & 2.00 & 1.78 \\
\hline Range of Premiums & $(0.5)-20.0$ & $0.9-17.6$ & $0.7-17.6$ & $0.6-17.6$ & $0.3-17.6$ & $(0.7)-17.6$ & $(0.1)-17.6$ \\
\hline $\begin{array}{l}\text { 10 Programs with } \\
\text { Lowest Premiums }\end{array}$ & $(0.5)-2.5$ & $1.0-1.5$ & $0.7-1.5$ & $0.6-1.3$ & $0.3-1.0$ & $(0.7)-0.9$ & $(0.1)-1.0$ \\
\hline $\begin{array}{l}\text { Number of Programs } \\
\text { Represented }\end{array}$ & 50 & 60 & 80 & 91 & 101 & 104 & 97 \\
\hline
\end{tabular}

${ }^{*}$ Represents the 10 utility programs with the lowest price premiums for new customer-driven renewable energy. This includes only programs that have installed-or announced firm plans to install or purchase power from-new renewable energy sources. In 2001, the discrepancy between the low end of the range for all programs and the Top 10 programs results from the program with the lowest premium $(0.9 \phi / \mathrm{kWh})$ not being eligible for the Top 10 because it was either selling some existing renewables or had not installed any "new" renewable capacity for its program. Source: Bird and Kaiser (2007)

\footnotetext{
${ }^{11}$ Some utilities periodically adjust the green power premium to reflect changes in the cost of fossil fuels used for electricity generation. Other utilities offer a fixed-rate green power product. In either case, when fuel prices increase, the effective green power premium falls. Utilities offering fixed-rate green power options or other types of fuel-price exemptions include Austin Energy, Alliant Energy, Clallum County PUD, Edmond Electric, Eugene Water and Electric Board, Green Mountain Power, Holy Cross Energy, Madison Gas \& Electric, OG\&E Electric Services, We Energies, and Xcel Energy.
} 


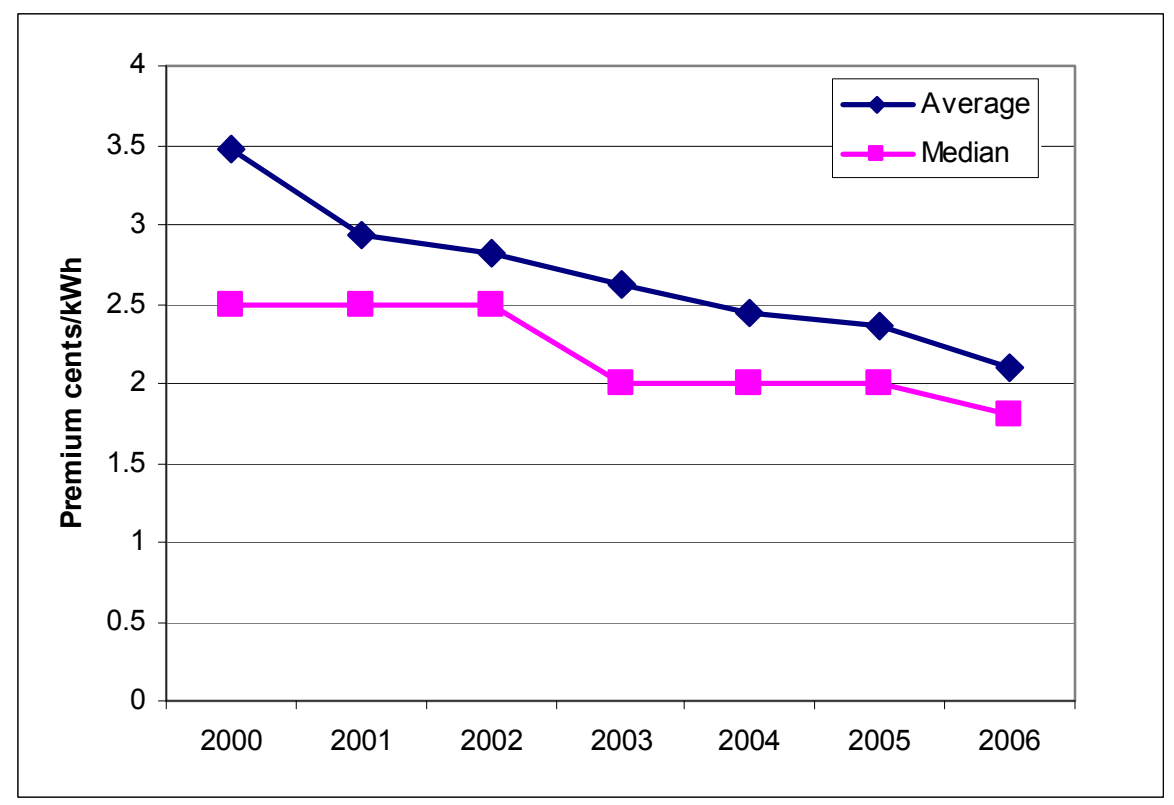

Figure 4. Trend in utility green pricing premiums, 2000-2006

\section{Green Pricing Sales}

Utility green pricing sales continue to exhibit strong growth. Collectively, utilities in regulated electricity markets sold about 3.4 billion kWh of green power to customers in 2006 (Table 7). Green pricing program sales to all customer classes grew by $39 \%$ in 2006, compared to rates ranging from $26 \%$ to $56 \%$ in recent years (Table 7; Figure 5). Sales growth is attributed to both continued expansion of the green power customer base as well as larger purchases by nonresidential customers.

Table 7. Annual Sales of Green Energy Through Utility Green Pricing Programs (Regulated Electricity Markets Only), millions of kWh

\begin{tabular}{|l|r|r|r|r|r|r|}
\hline & $\mathbf{2 0 0 1}$ & \multicolumn{1}{|c|}{$\mathbf{2 0 0 2}$} & $\mathbf{2 0 0 3}$ & $\mathbf{2 0 0 4}$ & \multicolumn{1}{c|}{$\mathbf{2 0 0 5}$} & \multicolumn{1}{c|}{$\mathbf{2 0 0 6}$} \\
\hline Sales to Residential customers & 400 & 661 & 874 & 1,295 & 1,606 & 2,103 \\
\hline Sales to Nonresidential customers & 173 & 234 & 410 & 544 & 842 & 1,302 \\
\hline Total Sales to All customers & 573 & 895 & 1,284 & 1,839 & 2,448 & 3,404 \\
\hline \% Annual Growth in Total Sales & $26 \%$ & $56 \%$ & $43 \%$ & $43 \%$ & $33 \%$ & $39 \%$ \\
\hline \% Nonresidential of Total Sales & $30 \%$ & $26 \%$ & $32 \%$ & $30 \%$ & $34 \%$ & $38 \%$ \\
\hline
\end{tabular}

Totals may not add due to rounding.

Source: Bird and Kaiser (2007) 


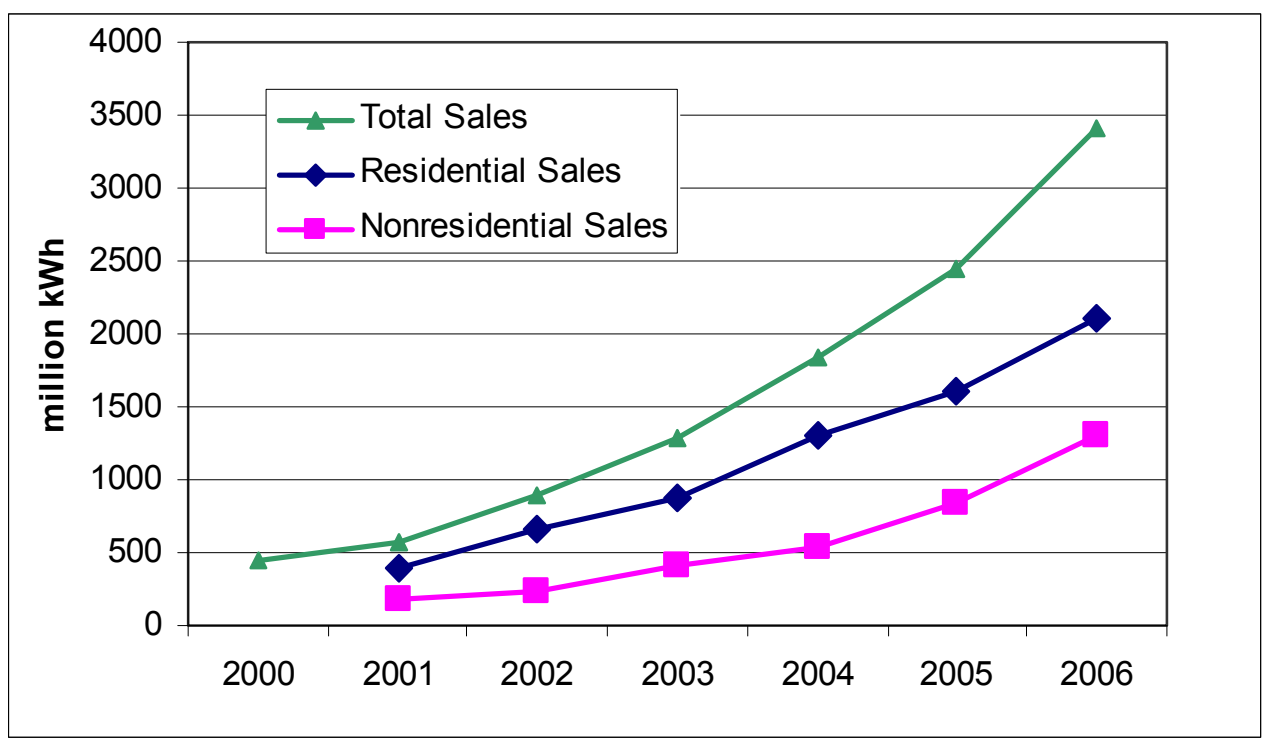

Figure 5. Annual sales of green energy through utility green pricing programs (regulated electricity markets only), millions of $\mathrm{kWh}$

Renewable energy sold through green pricing programs in 2006 represents an equivalent renewable energy capacity of more than $1,100 \mathrm{MW}$, with more than 1,000 MW of this represented by "new" renewable energy resources (Table 8). ${ }^{12} \mathrm{Wind}$, solar, and landfill gas are the renewable resources most commonly used for utility programs, with wind energy representing the largest portion of the total capacity. In 2005, sales of renewable energy through green pricing programs represented nearly $800 \mathrm{MW}$ of renewable energy capacity, with about $740 \mathrm{MW}$ of that from "new" renewable energy sources. Appendix A presents estimates of new capacity serving green pricing programs in earlier years.

Table 8. Renewable Energy Generation and Capacity Supplying Green Pricing Programs, 2006

\begin{tabular}{|l|r|r|r|r|r|r|r|}
\hline & $\begin{array}{c}\text { Landfill } \\
\text { Gas }\end{array}$ & Other Bio & Geothermal & Hydro & Solar & \multicolumn{1}{c|}{ Wind } & \multicolumn{1}{c|}{ Total } \\
\hline Sales MWh & 321,000 & 201,000 & 89,000 & 146,000 & 7,200 & $2,641,000$ & $3,404,000$ \\
\hline \% of Total Sales & $9.4 \%$ & $5.9 \%$ & $2.6 \%$ & $4.3 \%$ & $0.2 \%$ & $77.6 \%$ & $100.0 \%$ \\
\hline Capacity Factor & 0.9 & 0.8 & 0.9 & 0.5 & 0.2 & 0.3 & \\
\hline Total MW & 41 & 29 & 11 & 33 & 4 & 1,004 & 1,123 \\
\hline MW New RE $^{* *}$ & 27 & 16 & $<1$ & 5 & 4 & 992 & 1,044 \\
\hline
\end{tabular}

${ }^{*}$ Capacity factors are derived from EPRI/DOE 1997 and EIA 2006 to reflect a blend of technologies installed over time and in areas with varying resource quality.

**”New" renewables capacity is a subset of total capacity supplying green pricing programs.

\footnotetext{
${ }^{12}$ Capacity factors are derived from EPRI and U.S. DOE Renewable Energy Technology Characterizations, TR109496, December 1997.
} 


\section{Customer Participation}

At the end of 2006, more than 480,000 customers were participating in utility green pricing programs in regulated electricity markets (Table 9 ). ${ }^{13}$ As in the past, a relatively small number of green power programs account for the majority of customers, with just 10 programs accounting for $60 \%$ of all participants. ${ }^{14}$ From 2000 to 2006 , the number of customer participants increased nearly fourfold, with growth rates during the past several years ranging from $16 \%$ to $25 \%$.

Table 9. Estimated Cumulative Number of Customers Participating in Utility Green Pricing Programs

\begin{tabular}{|l|c|c|c|c|c|r|r|}
\hline Customer Segment & $\mathbf{2 0 0 0}$ & $\mathbf{2 0 0 1}$ & \multicolumn{1}{|c|}{$\mathbf{2 0 0 2}$} & \multicolumn{1}{|c|}{$\mathbf{2 0 0 3}$} & $\mathbf{2 0 0 4}$ & $\mathbf{2 0 0 5}$ & \multicolumn{1}{c|}{$\mathbf{2 0 0 6}$} \\
\hline Residential & 131,000 & 166,300 & 224,500 & 258,700 & 323,700 & 383,400 & 470,800 \\
\hline Nonresidential & 1,700 & 2,500 & 3,900 & 6,500 & 8,100 & 11,300 & 15,500 \\
\hline Total & 132,700 & 168,800 & 228,400 & 265,000 & 331,800 & 394,700 & 486,300 \\
\hline$\%$ Total Annual Growth & $98 \%$ & $27 \%$ & $35 \%$ & $16 \%$ & $25 \%$ & $19 \%$ & $23 \%$ \\
\hline$\%$ Residential Growth & n/a & $27 \%$ & $35 \%$ & $15 \%$ & $25 \%$ & $18 \%$ & $23 \%$ \\
\hline$\%$ Nonresidential Growth & n/a & $47 \%$ & $56 \%$ & $67 \%$ & $25 \%$ & $40 \%$ & $37 \%$ \\
\hline
\end{tabular}

Source: Bird and Kaiser 2007

Table 9 delineates residential and nonresidential customer participation in utility green pricing programs over time. The vast majority of participants are residential customers, with nonresidential customers accounting for only $3 \%$ of all participants. However, nonresidential participation is growing at a faster rate than residential participation, which is having a significant positive impact on overall sales volume because of the larger size of nonresidential purchases.

At the end of 2006, the average participation rate in utility green pricing programs among eligible utility customers was $1.8 \%$, with a median of $1 \%$ (Table 10 ). These industry-wide rates have shown very little change in recent years. The overall lack of improvement in participation rates results from a number of factors, including a lack of customer awareness of the green power program, ${ }^{15}$ customer unwillingness to pay a premium for green power, customer uncertainty regarding the actual benefits of the program, and varied levels of interest among utilities in marketing and promoting the program (Holt and Holt 2004, Swezey and Bird 2001). However, the top performing programs continue to show improvement, with participation rates ranging from about $5 \%$ to nearly $17 \%$ in 2006 , compared to a range of $3 \%$ to $6 \%$ in 2002 .

\footnotetext{
${ }^{13}$ NREL obtained consumer response data for nearly $70 \%$ of utility green pricing programs in 2006 , including all of the major programs. The remaining programs, which are smaller in size, do not have a large impact on overall participant numbers.

${ }^{14}$ NREL issues four different Top 10 lists based on total sales of renewable energy to program participants, total number of customer participants, customer participation rates, and the premium charged to support new renewables development. These lists can be found at http://www.eere.energy.gov/greenpower/markets/pricing.shtml?page=3.

${ }^{15}$ A number of utilities have reported that only $20 \%$ to $30 \%$ of their customers are aware that a green power option is offered.
} 
Table 10. Customer Participation Rates in Utility Green Pricing Programs

\begin{tabular}{|l|c|c|c|c|c|c|c|}
\hline $\begin{array}{l}\text { Participation } \\
\text { Rate }\end{array}$ & $\mathbf{2 0 0 0}$ & $\mathbf{2 0 0 1}$ & $\mathbf{2 0 0 2}$ & $\mathbf{2 0 0 3}$ & $\mathbf{2 0 0 4}$ & $\mathbf{2 0 0 5}$ & $\mathbf{2 0 0 6}$ \\
\hline Average & $1.2 \%$ & $1.3 \%$ & $1.2 \%$ & $1.2 \%$ & $1.3 \%$ & $1.5 \%$ & $1.8 \%$ \\
\hline Median & $0.7 \%$ & $0.7 \%$ & $0.8 \%$ & $0.9 \%$ & $1.0 \%$ & $1.0 \%$ & $1.0 \%$ \\
\hline $\begin{array}{l}\text { Top } 10 \\
\text { programs }\end{array}$ & $2.6 \%-$ & $3.0 \%-$ & $3.0 \%-$ & $3.9 \%-$ & $3.8 \%-$ & $4.6 \%-$ & $5.1 \%-$ \\
\hline
\end{tabular}

In 2006, utilities reported that an average of $6 \%$ and a median $4 \%$ of customers dropped out of green pricing programs. Thus, retention rates continue to improve, despite the fact that electricity and energy prices have remained high in most regions of the country. This finding suggests that customers tend to be "sticky" and maintain participation in green power programs, despite electricity and other energy cost increases (Bird and Kaiser 2007). 


\section{Competitive Green Power and REC Markets}

About one-third of U.S. states have restructured their electricity markets to introduce retail service competition. Currently, electricity consumers in the following states can purchase competitively marketed green power: Connecticut, Maine, Maryland, Massachusetts, New Jersey, New York, Pennsylvania, Rhode Island, Texas, and Virginia, as well as the District of Columbia (Figure 6 and Appendix F). ${ }^{16,17}$ Competitively marketed green power offerings are also available to nonresidential consumers in a few other states.

Initially, buying green power in competitive retail markets entailed switching electricity service from the incumbent utility to a green power supplier. However, with few exceptions, green power marketers have found it difficult to compete or to persuade customers to switch suppliers. As a remedy, a number of states now require default suppliers (which are often the incumbent distribution utilities) to offer green power options to their customers. These load serving entities typically provide customers with underlying electricity generation, combined with a choice of several green products offered by competing green power marketers. In addition, several utility suppliers have voluntarily teamed with a single green power marketer to offer a green power option to their customers. Utility/marketer partnership programs are now offered in Connecticut, Massachusetts, New Jersey, New York, Pennsylvania, and Rhode Island.

RECs provide another alternative to switching electricity suppliers. Also known as "green tags" or tradable renewable certificates (TRCs), RECs represent the "green" attributes of renewable energy generation and can be sold separately from commodity electricity. REC-based products may be supplied from a variety of renewable energy sources throughout the country and sold to customers nationally, or they may be supplied from renewable energy sources in a particular region or locality and marketed as such to local customers. More than 20 companies offer certificate-based green power products to retail customers via the Internet, and a number of other companies market RECs solely to commercial and industrial customers (Appendix G). ${ }^{18}$

RECs are also sold in the wholesale market and are frequently used by utilities and marketers who bundle the RECs with commodity electricity to sell green power to retail customers. In fact, RECs are used to supply most of the programs in which default suppliers have teamed with green power marketers. Thus, it can be difficult to distinguish REC products from other green power offerings. This is particularly true when REC products are supplied from renewable sources located in the same region in which they are marketed.

\footnotetext{
${ }^{16}$ For an up-to-date list of products offered by competitive green power marketers, see the U.S. Department of Energy's Green Power Network Web site at http://www.eere.energy.gov/greenpower/markets/marketing.shtml?page=1

${ }^{17}$ We do not include Oregon and Ohio in this list. In Oregon, only large commercial and industrial customers are able to switch to competitive green power providers; residential and small commercial customers have access to green power options offered by the incumbent utilities, which we categorize as green pricing. In Ohio, at least one green power marketer supplied customers of municipal aggregation groups with a "cleaner energy" product, but the renewable energy content was very low (this offering was terminated at the end of 2005). Green power is not offered more broadly in the Ohio market.

${ }^{18}$ For an up-to-date list of companies offering REC-based green power products, see the U.S. Department of Energy's Green Power Network Web site at: http://www.eere.energy.gov/greenpower/markets/certificates.shtml?page=1
} 


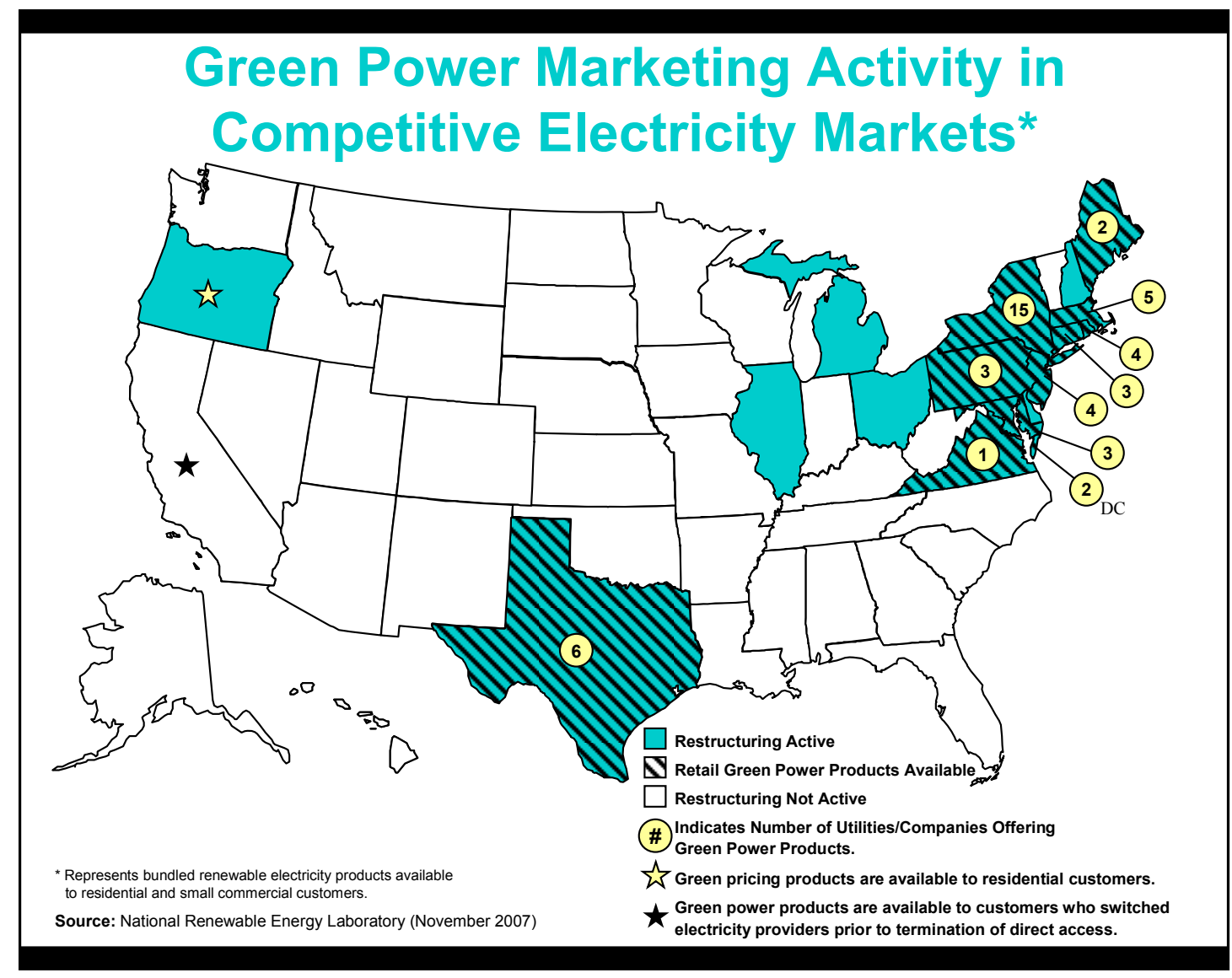

Figure 6. Green power marketing activity in competitive electricity markets

\section{Products and Pricing}

Green power products offered in competitive markets tend to differ from those offered by utilities in regulated markets in that they may contain a mix of electricity generated from new and preexisting renewable energy projects, whereas utility green pricing programs generally utilize only "new" renewable energy supplies. One reason for this difference is that competitive suppliers are subject to price competition, and existing resources are typically available at lower costs. Also, when markets initially opened to competition, green power marketers often were forced to offer existing renewables because of a lack of "new" renewable energy supplies. However, as new renewable energy facilities have come online, the fraction of new renewables in competitive retail products has increased. In addition, green power product certification programs, which set standards for product quality, have required increasing amounts of "new" renewables. Beginning January 1, 2007, the Green-e certification program began requiring that all certified products to be supplied exclusively from "new" renewable energy projects. ${ }^{19}$ Similarly, the U.S. Environmental Protection Agency's (EPA) Green Power Partnership now requires its partners to purchase "new" renewables to meet its minimum purchase criteria. ${ }^{20}$

\footnotetext{
${ }^{19}$ Administered by the San Francisco-based Center for Resource Solutions, the Green-e program certifies retail and wholesale green power products that meet its environmental and product content standards. For details on the Green-e National Standard, see http://www.green-e.org/.

${ }^{20}$ See http://www.epa.gov/greenpower.
} 
The price premium charged for competitive market products depends on several factors such as the price of standard offer or default service, the availability of incentives to green power marketers or suppliers, and the cost of renewable energy generation available in the regional market. Some marketers charge prices close to or even below the default market price; others offer fixed-price products, which provide customers with protection against increasing prices for a specified period of time, usually one year.

Competitively marketed green power products generally carry a price premium of between $1 \phi / \mathrm{kWh}$ and $2.5 \phi / \mathrm{kWh}$ for residential and small commercial customers, although offerings have ranged from discounts to a premium of about $10 \phi / \mathrm{kWh}$ in recent years. The renewable energy sources most commonly used to supply competitive green power offerings are wind, landfill gas, and small or low-impact hydropower, while a number of products also contain a small amount of solar energy. Higher-priced products often contain a larger fraction of "new" renewable energy content or resources that are more desirable to consumers, such as new wind and solar.

Similar to competitively marketed products, retail prices charged for REC products typically range from about $1 \phi / \mathrm{kWh}$ to $2.5 \phi / \mathrm{kWh}$ for residential and small commercial customers. In most cases, larger customers are able to negotiate lower prices. Nearly all REC products are sourced from new renewable energy generation projects, which is a requirement of both Green-e certification and the Environmental Resources Trust Ecopower program. Similarly, the U.S. EPA Green Power Partnership requires its partners to procure new renewables to meet the program's minimum purchase requirements.

Purchasers often seek certification out of concerns over "double counting" and to ensure a level of oversight and auditing because RECs are generally not subject to the same regulatory scrutiny as electricity. Table 11 indicates that more than $80 \%$ of RECs and green power are certified at the retail or wholesale level by the Green-e certification program, based on NREL estimates and data from the 2006 Green-e Verification report. Note that the Green-e and NREL REC figures differ because some of the wholesale Green-e certified RECs are used to supply green pricing programs or competitively marketed retail products.

Table 11. Total Sales of Green-e Certified Renewable Energy, 2006 million kWh

\begin{tabular}{|l|c|c|c|c|}
\hline & Residential & Commercial & Wholesale & Total \\
\hline RECs & 39 & 3,495 & 5,223 & 8,757 \\
\hline Green Pricing & 484 & 125 & 0 & 609 \\
\hline Competitive Electricity & 84 & 273 & 148 & 505 \\
\hline Total & 607 & 3,893 & 5,371 & 9,871 \\
\hline
\end{tabular}

Source: Center for Resource Solutions 2007

Wind energy is the most commonly used renewable energy source for RECs, although some REC products feature other renewable energy sources or blends of renewable sources, such as biomass (typically from bio-methane sources) and solar. 


\section{Customer Participation}

Based on data received from green power marketers, we estimate that as many as 220,000 retail customers were purchasing green power from competitive suppliers or as unbundled RECs at the end of 2006 (Table 12). This number includes more than 80,000 participants in utility/marketer programs available in competitive markets. The number of customers participating in utility/marketer programs grew faster than utility green pricing programs as a whole $(34 \%$ compared to $23 \%$, respectively), likely because many of these programs are still relatively new.

In competitive markets, the vast majority of customers purchasing green power are residential customers. Of the 220,000 retail customers, about 10,000 purchase REC-only products. While most of the REC purchasers are also residential customers, the vast majority of REC sales on a $\mathrm{kWh}$-basis are made to nonresidential customers due to the much larger purchase sizes.

Table 12. Estimated Cumulative Number of Customers Purchasing RECs or Green Power from Competitive Marketers, 2002-2006

\begin{tabular}{|l|c|c|c|c|c|}
\hline & $\mathbf{2 0 0 2}$ & $\mathbf{2 0 0 3}$ & $\mathbf{2 0 0 4}$ & $\mathbf{2 0 0 5}$ & $\mathbf{2 0 0 6}$ \\
\hline Competitive Markets & $\sim 150,000$ & $\sim 170,000$ & $<140,000$ & $>180,000$ & $\sim 210,000$ \\
\hline RECs $^{*}$ & $<10,000$ & $<10,000$ & $<10,000$ & $<10,000$ & $\sim 10,000$ \\
\hline Total & $<160,000$ & $\sim \mathbf{1 8 0 , 0 0 0}$ & $<150,000$ & $\sim 190,000$ & $\sim \mathbf{2 2 0 , 0 0 0}$ \\
\hline$\%$ Change & n/a & $13 \%$ & $-17 \%$ & $27 \%$ & $16 \%$ \\
\hline
\end{tabular}

*Includes only end-use customers purchasing RECs separate from electricity.

In recent years, most of the customer gains in competitive markets resulted from utility/marketer partnership programs in the Northeast as well as customers who switched from default service to retail green power providers in a few states, most notably Texas. These gains were tempered by losses in some states, where marketers struggled to provide electricity service to consumers amidst adverse market conditions and increasing costs. For example, one marketer ceased offering electricity generation service to its 30,000 customers in Pennsylvania in late 2005, citing adverse market rules and conditions that increased its operating costs. The company instead began offering an unbundled REC-based product supplied from national renewable energy resources, but likely suffered losses when turning back its customers to default electricity service. ${ }^{21}$ In addition, EIA data show declines in the number of green power customers in Virginia, and Washington D.C. during 2006 (see Appendix C).

\footnotetext{
${ }^{21}$ Green Mountain Energy Company News Release, October 11, 2005, “Green Mountain Energy Company Introduces New Renewable Energy Product in Pennsylvania." http://www.greenmountain.com/about/press events/prviewer.jsp?dbId=18, accessed November 10, 2006. Green Mountain quit the Ohio market at the same time, citing the Federal Energy Regulatory Commission's implementation of Seams Elimination Charge Adjustment and its resulting litigation, in addition to unexpected charges associated with the start of Midwest Independent Transmission System Operator Inc.'s Day II energy markets (see Austin Business Journal article, October 26, 2005 http://www.bizjournals.com/austin/stories/2005/10/24/daily30.html?from_rss=1).
} 


\section{Green Power Sales}

An estimated 8.5 billion $\mathrm{kWh}$ of renewable energy was sold to retail customers by competitive green power and REC marketers in 2006 (Table 13). This figure includes renewable energy from both existing and new sources.

About 1.7 billion $\mathrm{kWh}$ of the total was sold as a bundled green power product in competitive electricity markets - a 20\% decline from 2005. As noted earlier, the decline in sales of green power in competitive markets occurred as a result of adverse market conditions and increasing costs of serving customers with electricity in states such as Pennsylvania. The competitive market sales figure includes renewable energy sales through default utility/marketer programs or individual utility/marketer partnership in competitive markets, which amounted to approximately 425 million kWh in 2006 (Bird and Kaiser 2006). Retail REC sales increased by about 75\%, reaching 6.8 billion $\mathrm{kWh}$ in 2006 . Most of the growth in REC-only sales is attributable to the nonresidential sector.

Table 13. Retail Sales of Renewable Energy in Competitive Markets and RECs* (million kWh)

\begin{tabular}{|c|c|c|c|c|}
\hline & 2003 & 2004 & 2005 & 2006 \\
\hline \multicolumn{5}{|c|}{ Competitive Markets } \\
\hline Residential & $\mathrm{n} / \mathrm{a}$ & 2,140 & 1,330 & 1,000 \\
\hline Nonresidential & $\mathrm{n} / \mathrm{a}$ & 510 & 820 & 710 \\
\hline Subtotal & 1,900 & 2,650 & 2,150 & 1,720 \\
\hline$\%$ Change & & $40 \%$ & $-19 \%$ & $-20 \%$ \\
\hline$\%$ Residential & & $81 \%$ & $62 \%$ & $59 \%$ \\
\hline \multicolumn{5}{|l|}{ RECs $^{* *}$} \\
\hline Residential & $\mathrm{n} / \mathrm{a}$ & 40 & 40 & 110 \\
\hline Nonresidential & $\mathrm{n} / \mathrm{a}$ & 1,690 & 3,840 & 6,700 \\
\hline Subtotal & 660 & 1,720 & 3,890 & 6,810 \\
\hline$\%$ Change & & $160 \%$ & $126 \%$ & $75 \%$ \\
\hline \% Residential & & $2 \%$ & $1 \%$ & $2 \%$ \\
\hline Total Sales & 2,560 & 4,370 & 6,040 & 8,530 \\
\hline \% Change & & $71 \%$ & $38 \%$ & $41 \%$ \\
\hline
\end{tabular}

n/a = not available

*Totals may not add due to rounding.

${ }^{* *}$ Includes only RECs sold to end-use customers separate from electricity. RECs are often purchased wholesale to supply utility and competitively marketed products and bundled with electricity. RECs bundled with electricity are included in utility green pricing and competitive market sales estimates.

Table 13 also delineates green power sales by customer segment. In 2006, similar to the previous year, about $60 \%$ of green power sales in competitive markets were to residential customers. In contrast, nearly all unbundled REC sales were to nonresidential customers. Generally, nonresidential customers find REC-only products attractive because of their flexibility and the greater potential for cost savings because they can be sourced from renewable energy projects in more favorable resource locations and the electricity need not be delivered directly to the customer, which lowers transaction costs. On the other hand, residential customers may be not be 
aware that RECs are available or may not understand them. For commercial and institutional customers that operate facilities in multiple locations across the country, RECs may also provide a more efficient green power sourcing solution than working with utilities in each individual utility territory. ${ }^{22}$

In 2006, renewable energy sold in competitive markets or as unbundled RECs represented an equivalent renewable energy capacity of more than 2,400 MW, with more than 2,100 MW of this total coming from "new" renewable energy resources (Table 14). Wind energy supplied 56\% of sales, followed by biomass and landfill gas (27\%), geothermal (9\%), hydropower-often from small or low-impact installations- $(7 \%)$, and solar (1\%).

Table 14. Renewable Energy Sources Supplying Competitive and REC Markets, 2006

\begin{tabular}{|l|c|c|c|c|c|c|}
\hline & $\begin{array}{c}\text { Biomass/ } \\
\text { Landfill } \\
\text { Gas }\end{array}$ & $\begin{array}{c}\text { Geo- } \\
\text { thermal }\end{array}$ & Hydro & Solar & Wind & Total \\
\hline MWh Sales & $2,269,000$ & 776,000 & 620,000 & 56,000 & $4,807,000$ & $8,528,000$ \\
\hline \% of Total Sales & $27 \%$ & $9 \%$ & $7 \%$ & $1 \%$ & $56 \%$ & $100 \%$ \\
\hline Capacity Factor & $85 \%$ & $90 \%$ & $50 \%$ & $20 \%$ & $30 \%$ & n/a \\
\hline Total MW & 304 & 98 & 142 & 32 & 1,830 & 2,406 \\
\hline MW New RE & $\mathbf{1 7 2}$ & $\mathbf{7 5}$ & $\mathbf{2 5}$ & $\mathbf{3 0}$ & $\mathbf{1 , 8 3 0}$ & $\mathbf{2 , 1 3 0}$ \\
\hline
\end{tabular}

${ }^{*}$ Capacity factors are derived from EPRI/DOE 1997 and EIA 2006 to reflect a blend of technologies installed over time and in areas with varying resource quality.

\footnotetext{
${ }^{22}$ For example, the EPA Green Power Partnership reports that the majority of its top 25 partners purchase RECs (Appendix B). See http://www.epa.gov/greenpower/. In addition, the Green Power Market Development Group promotes the purchase of RECs among its members. .... . See http://www.thegreenpowergroup.org/.
} 


\section{Market Trends and Issues}

Taken as a whole, the voluntary green power market continues to exhibit strong growth. However, green power markets do not operate in isolation from other markets and are also impacted by both state and federal policy initiatives and changes. In this section, we briefly describe a number of market and policy developments that will have an important influence on the future of green power markets.

\section{Influence of Renewable Portfolio Standards on Green Power Markets}

To date, renewable portfolio standards (RPS) requiring utilities or electricity providers to supply a certain quantity of their delivered energy from renewable energy sources have been adopted in 25 states and the District of Columbia. These requirements call for as much as $20 \%$ to $30 \%$ of electricity to come from renewable energy sources in the next 15 to 20 years. As the geographic coverage and stringency of these mandates for renewable energy grow, one question that has arisen is whether such policies will have a negative impact on participation in voluntary renewable energy markets. In addition, some have questioned whether there is a need for voluntary markets if compliance obligations are established, as customers may begin to rely on policies to support renewable energy.

A recent NREL analysis (Bird and Lokey 2007) found that there is little evidence to date to suggest that the adoption of an RPS will negatively affect voluntary market sales. Figure 7 shows the historic and current sales of renewable energy through green pricing programs in four states with an RPS in place. The year that the RPS was adopted or modified is listed in parentheses in the legend of the figure. To date, there is no apparent decline in sales once the RPS is adopted. In fact, sales continue to grow over time.

Furthermore, the analysis found that customer participation rates in utility green power programs were higher on average in states with an RPS than in those without. This finding was statistically significant based on an analysis of 2006 customer participation data provided by utilities. While it is not likely that the mere presence of an RPS encourages consumers to make voluntary green power purchases, the higher voluntary participation rates in states with RPS may be explained by a number of factors, such as: 1) consumers in RPS states may be more prone to support renewable energy in general, 2) consumers may be more aware of the benefits of renewable energy due to education about the benefits of the RPS policy, 3) some successful green pricing programs may be offered by public or cooperative utilities that are not subject to the state RPS, and 4) there may be more renewable energy supplies in states with an RPS which keeps prices relatively low for green power consumers, encouraging participation. On the other hand, the authors found no statistically significant difference in average renewable energy sales rates (as opposed to customer participation rates) through utility green power programs in states with and without an RPS. 


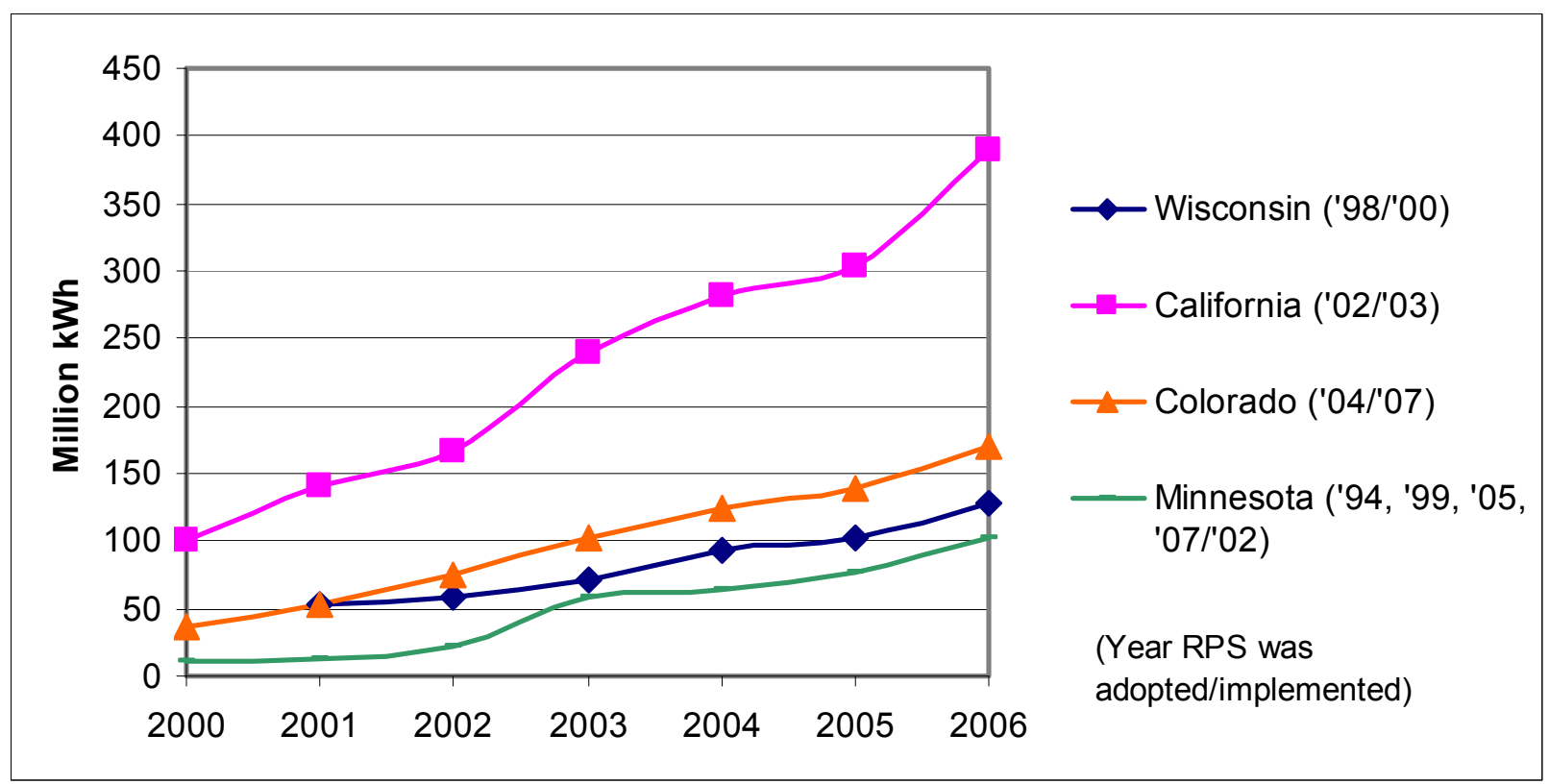

Figure 7. Voluntary green power sales in selected states with RPS

Figure 8 shows the relative magnitude of renewable energy sales through utility green power programs by state and whether an RPS policy has been enacted. The figure shows that many of the states that lead in terms of consumer purchases through voluntary utility green power programs also have RPS policies in place. The notable exceptions are Florida, Tennessee, and Oklahoma, which do not have RPS policies. 


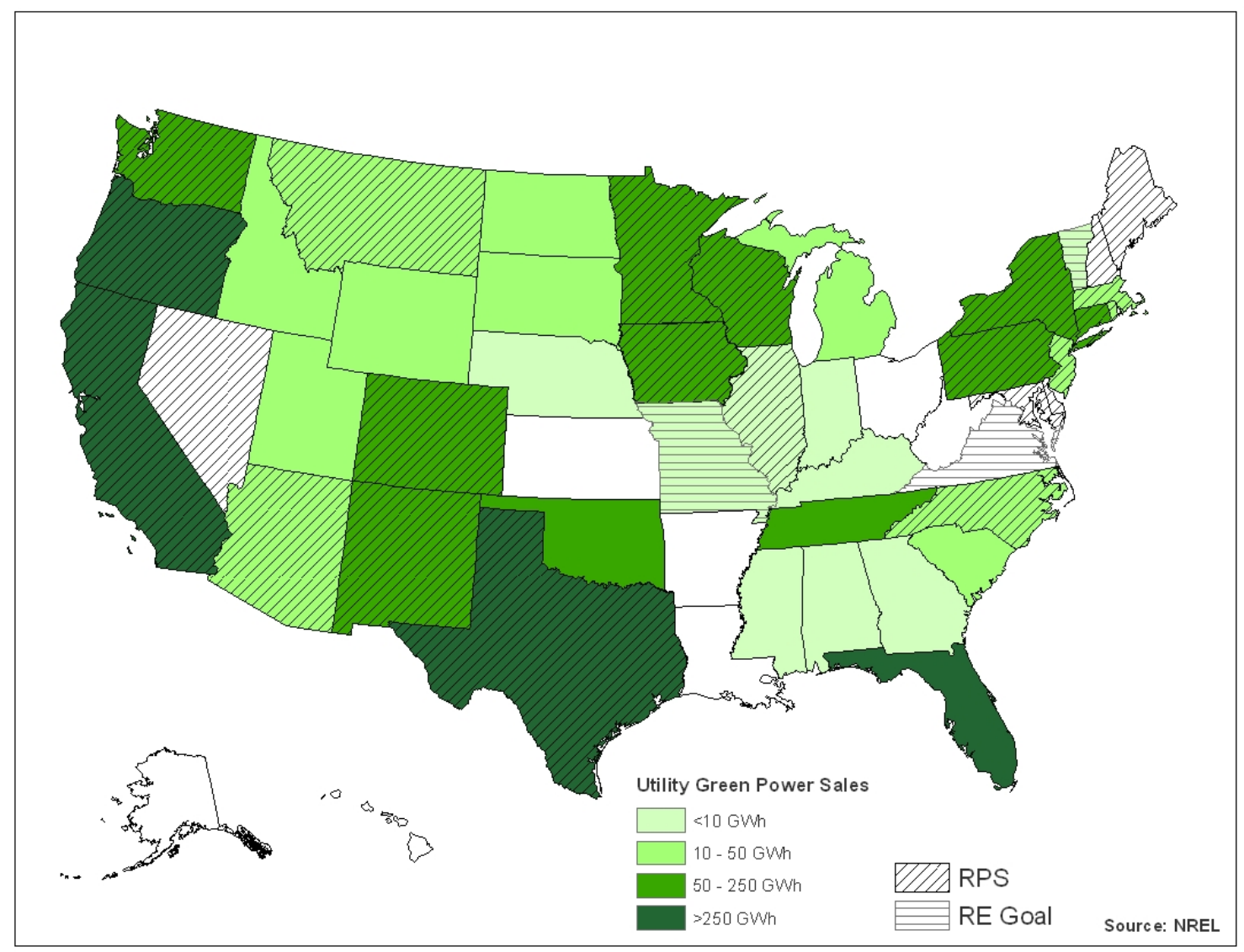

Figure 8. Voluntary green power purchases through utility programs in states with RPS

Even though these data suggest that voluntary market sales remain robust in states with an RPS, looking forward, this issue might require additional analysis once higher RPS penetration levels are achieved. It is possible that more aggressive policies could impact voluntary market participation. For example, RPS policies could limit green pricing or REC sales or participation if supply shortages were to arise. In this case, compliance obligations might limit the amount of renewable energy available to voluntary green pricing programs, or higher prices might discourage participation. However, it is likely that such shortages would be short term in nature.

It is also important to note that voluntary market demand has demonstrated consumer support for renewable energy, contributing to the development or expansion of RPS policies in some instances. For example, in Colorado, voluntary market support was an important driver for wind energy development in the mid to late 1990s prior to the adoption of an RPS. The very favorable consumer response to Xcel Energy's Windsource program demonstrated that there was considerable support for renewable energy and set the stage for the adoption of a statewide RPS by a voter-approved ballot initiative in 2004. Similarly, success of utility green pricing programs in Wisconsin helped facilitate the expansion of the state's RPS in 2006. Because of the emphasis on marketing, voluntary green power programs can raise awareness and educate consumers about the benefits of renewable energy in general, which may be important to the passage of an RPS. 


\section{Supply and Demand Balance of Renewable Electricity}

Recent growth in voluntary market purchases has depended on an adequate supply of renewable electricity at a reasonable price. In recent years, the demand for renewable electricity has accelerated as a consequence of state and federal policies and the growth of voluntary green power purchase markets, along with the generally improving economics of renewable energy development.

For example, voluntary markets have grown at an average annual rate of about $50 \%$ for the past several years, and RPS policies have proliferated. However, U.S. non-hydro renewable electricity generation provided only about $2.3 \%$ of total U.S. electricity supply in $2005 .{ }^{23}$ And global demand for renewable energy equipment has recently led to supply shortages for wind turbines and photovoltaic modules. The rapid growth in demand for renewable energy has raised the question of whether there are sufficient renewable energy supplies to meet both RPS and voluntary market demand.

A recent preliminary analysis conducted by NREL (Swezey, et al. 2007) identified a potential shortfall of renewable energy supply to meet projected demand from RPS and voluntary purchase markets nationally. Figure 9 compares the estimated demand for "new" renewable electricity from voluntary and compliance (RPS) markets with two renewable electricity supply scenarios (a base case and a high wind case) for the period 2004 through 2010. Voluntary market demand is currently, and is expected to remain, below both existing and projected renewable electricity supply. ${ }^{24}$ However, when combined with RPS requirements, total demand from these two markets already slightly exceed the available supply of "new" renewable electricity, and the gap becomes more pronounced through 2010 as state RPS requirements ramp up. Under a more optimistic growth path for new wind energy capacity additions, the gap narrows considerably, but there is still a supply shortage. In 2010, the projected renewable electricity shortfall is 28 million MWh under the base-case scenario and 8 million MWh under the high-wind scenario.

If renewable electricity shortages develop, it is likely that renewable electricity prices will rise. Higher prices would dampen voluntary demand and RPS demand might even outbid some existing voluntary demand as state non-compliance penalties and alternative compliance payment levels set the market price. Other factors that could affect growth in voluntary markets are competition from energy efficiency certificates and demand for carbon offsets. In addition, demand for voluntary market RECs could decline if carbon regulations are adopted that prevent green power purchases from affecting greenhouse gas (GHG) emissions levels and thus limit claims that can be made by marketers and purchasers.

It is important to note, however, that regional differences may result in greater availability of supply for the voluntary market than suggested by the aggregate national picture. Some states, such as Texas, may have renewable energy generation in excess of that needed to meet RPS requirements, while others may experience shortages. Any excess generation that is not eligible to be used for RPS compliance would be available to meet voluntary market demand. State or

\footnotetext{
${ }^{23}$ U.S. Energy Information Administration, Electric Power Annual 2005, Revised Data, DOE/EIA-0348(2005), November 2006. http://www.eia.doe.gov/cneaf/electricity/epa/epa sum.html

${ }^{24}$ Voluntary market sales are assumed to grow at an annual rate of $35 \%$ through 2010 in the analysis, which is less than the $50 \%$ annual average growth rate realized in recent years.
} 
region-specific analyses are necessary to better understand the impact of regional supply and demand balances on renewable electricity availability for voluntary markets.

Further, while the analysis suggests a near-term deficit in renewable electricity supplies, the results do not necessarily portend a long-term shortage as it is likely that, with continuing Federal and state support, the renewable energy industry can greatly ramp up deployment and production over the medium and long term.

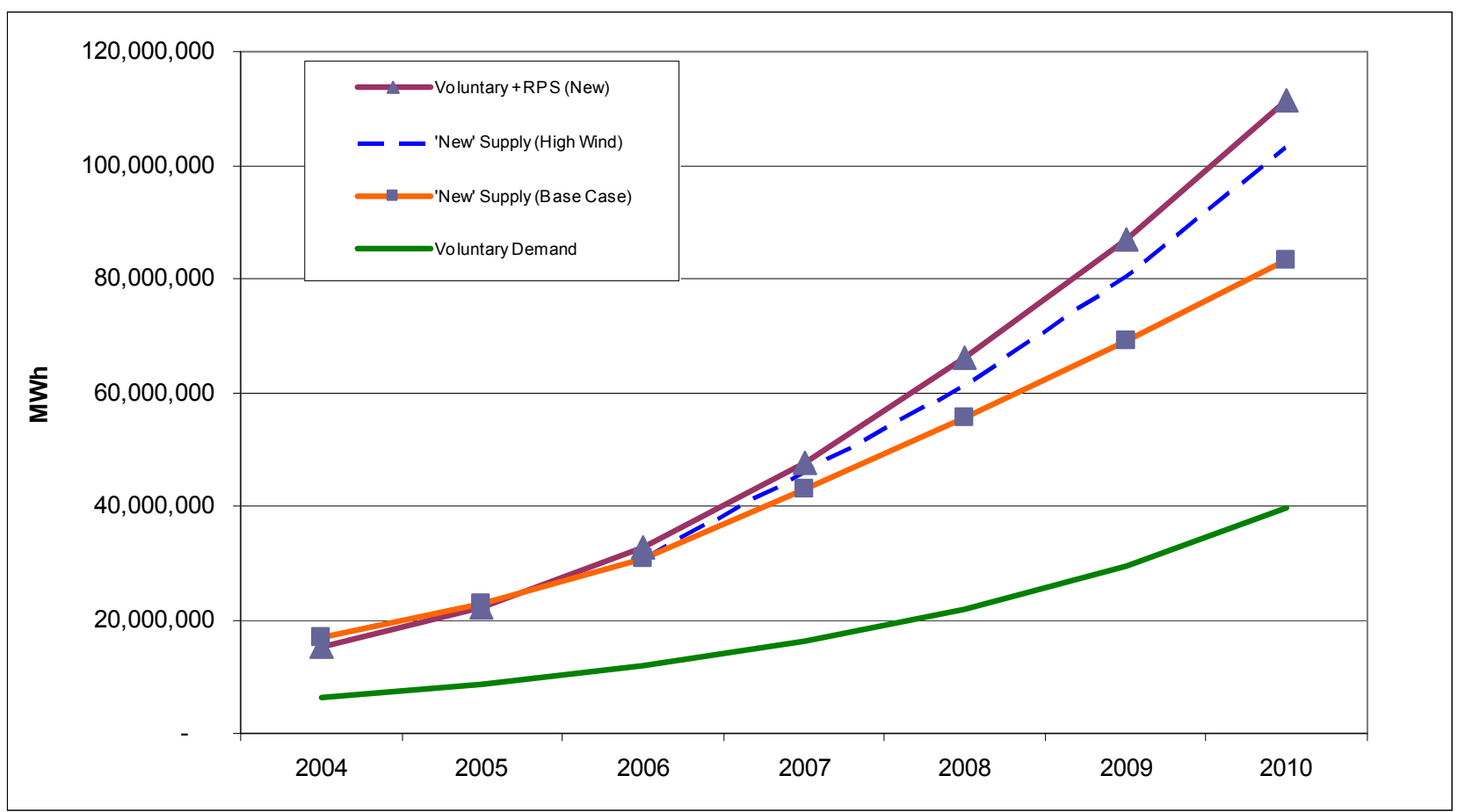

Figure 9. Estimated and projected supply and demand for renewable electricity

\section{Carbon Market Interaction Issues}

Carbon control policies are taking shape in the Northeast, Midwest, and Western regions of the United States, while carbon regulation continues to be debated at the national level. The treatment of renewable energy under these evolving programs and whether renewable energy purchases will affect overall carbon dioxide $\left(\mathrm{CO}_{2}\right)$ emissions levels has important implications for voluntary green power markets. Currently, many nonresidential customers in particular purchase green power (mostly as RECs) for its greenhouse gas benefits (i.e., lack of $\mathrm{CO}_{2}$ emissions). The design details of emerging cap and trade programs, such as whether renewable generation actually reduces the number of emission allowances available to emitting sources, have the ability to affect the $\mathrm{CO}_{2}$ emissions benefits. ${ }^{25}$

The Regional Greenhouse Gas Initiative (RGGI), which involves 10 states in the Northeast, is slated to be the first U.S.-based carbon cap and trade program. Currently, participating states are in the process of finalizing implementation rules in anticipation of the official launch in 2009.

25 For additional discussion, see Bird, et al. 2007. 
Under the RGGI program, voluntary purchases of green power will only result in the reduction of overall $\mathrm{CO}_{2}$ emission levels if participating states adopt the "voluntary market set aside" provision that was included in the Model Rule. ${ }^{26}$ This provision enables states to set aside and retire allowances equivalent to voluntary purchases of renewable energy by consumers.

As of October 2007, two states (Connecticut and Rhode Island) had adopted the voluntary market set aside in implementing legislation, while another four states (Massachusetts, Maryland, New Hampshire, and New York) have included it in draft rules or legislation. Two states did not include it in implementing legislation (Maine and Vermont), while the remaining two states (New Jersey and Delaware) have yet to address it (Holt 2007). In the states that do officially adopt the set aside for voluntary purchases, marketers and purchasers will be able to make substantiated claims of $\mathrm{CO}_{2}$ emissions benefits. In those states that do not adopt the provision, voluntary green power purchases will not affect overall $\mathrm{CO}_{2}$ emissions levels and marketing claims will need to be adjusted accordingly.

In November 2007, Governors of 10 Midwestern states signed the Midwestern Regional Greenhouse Gas Reduction Accord, which sets a goal of establishing a multi-sector cap and trade program for participating states. The Western Climate Initiative, which involves 6 Western states, continues to move forward as well, but detailed implementation plans have yet to be released. Therefore, it is unclear how voluntary renewable energy markets may be affected by these emerging programs at this time.

\footnotetext{
${ }^{26}$ See the RGGI Model Rule at http://www.rggi.org/modelrule.htm.
} 


\section{Conclusions and Observations}

The green power market continues to exhibit strong growth and provide an important demanddriven stimulus for renewable energy development. Green power markets provide an additional revenue stream for renewable energy projects, and raise consumer awareness of the benefits of renewable energy. Based on this review, we have identified the following market trends:

- In 2006, retail sales of renewable energy in voluntary purchase markets totaled 12 billion $\mathrm{kWh}$, representing a capacity equivalent of 3,500 MW of renewable energy, including $3,100 \mathrm{MW}$ from "new" renewable energy sources. The latter figure corresponds to nearly $30 \%$ of the total renewable energy capacity additions since 1997; thus, green power purchases are providing support for a significant fraction of new renewable energy projects, nationally.

- Wind energy provided $62 \%$ of green power sales, followed by biomass energy sources including landfill gas (23\%), geothermal (7\%), hydropower (6\%), and solar (1\%).

- Total market sales increased by about $40 \%$ in 2006 , with much of this growth driven by REC sales to nonresidential consumers. As a result, commercial and institutional REC markets now represent more than half of total green power market sales, surpassing sales in competitive electricity markets and utility green pricing programs.

- Utility green pricing programs in regulated electricity markets continued to show steady growth, with sales increasing by nearly $40 \%$ in 2006 . However, a relatively small number of utility programs continue to dominate sales and customer numbers. This suggests both that many programs are not achieving their full potential and that stronger performance is possible with effective program design and implementation along with dedicated marketing.

- Utility green pricing premiums have continued to fall, owing to a combination of higher prices of conventional generation fuels and lower renewable resource costs.

- Competitive markets continued to exhibit volatility, with sales declining $20 \%$ during 2006. Difficulties posed by market rules and conditions, as well as the continuing challenge of convincing customers to switch electricity providers, has led marketers to continue to shift away from delivered renewable electricity products toward marketing REC products, as well as to pursue partnerships with default suppliers to supply and market green power. Despite the losses in competitive markets, programs in which marketers have teamed with default suppliers continued to exhibit strong growth in both sales and customers during 2006, showing that utility/marketer partnerships hold promise for future growth.

- In 2006, sales to nonresidential customers continued to outpace those to residential consumers, bringing the fraction of nonresidential sales to nearly three-quarters of all green power sales on a $\mathrm{kWh}$-basis. The growing dominance of nonresidential sales is a departure from the early history of green power markets when most products and programs were oriented toward residential customers. Looking forward, demand by the nonresidential sector appears to be increasing and will likely continue to drive future voluntary market growth. 
- Overall, the number of customers purchasing green power increased by roughly $20 \%$, with gains in utility green pricing programs and utility/marketer programs offsetting losses in some competitive retail markets. 


\section{References}

Bird, L.; Holt, E.; Carroll, G. 2007. Implications of Carbon Regulation for Green Power Markets, NREL/TP-640-41076. Golden, CO: National Renewable Energy Laboratory, April. http://www.eere.energy.gov/greenpower/resources/pdfs/41076.pdf

Bird, L.; Lokey, E. 2007. Interaction of Compliance and Voluntary Renewable Energy Markets, NREL/ TP-670-42096. Golden, CO: National Renewable Energy Laboratory, October. http://www.eere.energy.gov/greenpower/pdfs/42096.pdf

Bird, L; Kaiser, M. 2007. Trends in Utility Green Pricing Programs (2006), 2007. NREL/TP670-42287. Golden, CO: National Renewable Energy Laboratory, October.

Bird, L.; Swezey, B. 2006. Green Power Marketing in the United States: A Status Report (Ninth Edition), NREL/TP-620-40904. Golden, CO: National Renewable Energy Laboratory, November. http://www.eere.energy.gov/greenpower/resources/pdfs/40904.pdf

Bird, L.; Swezey, B. 2005a. Green Power Marketing in the United States: A Status Report (Eighth Edition), NREL/TP-620-38994. Golden, CO: National Renewable Energy Laboratory, October. http://www.eere.energy.gov/greenpower/resources/pdfs/38994.pdf

Bird, L. Swezey, B. 2005b. "Estimates of New Renewable Energy Capacity Serving U.S. Green Power Markets” National Renewable Energy Laboratory, September. http://www.eere.energy.gov/greenpower/resources/tables/new_gp_cap.shtml

Bird, L.; Swezey, B. 2004. Green Power Marketing in the United States: A Status Report (Seventh Edition), NREL/TP-620-36823. Golden, CO: National Renewable Energy Laboratory, September. http://www.eere.energy.gov/greenpower/pdfs/36823.pdf

Bird, L.; Swezey, B. 2003. Green Power Marketing in the United States: A Status Report (6 ${ }^{\text {th }}$ Edition), NREL/TP-620-35119. Golden, CO: National Renewable Energy Laboratory, October. http://www.eere.energy.gov/greenpower/resources/pdfs/35119.pdf

Center for Resource Solutions (CRS) 2007. 2006 Green-e Energy Verification Report, San Francisco, California, November. http://www.green-e.org/publications.shtml

Electric Power Research Institute (EPRI) and U.S. Department of Energy (DOE), 1997. Renewable Energy Technology Characterizations, TR-109496, December.

Holt, E. 2007. "Support for Renewable Energy Marketing Claims in State Carbon Policies," Presentation to the Twelfth National Renewable Energy Marketing Conference, Philadelphia, PA, October 22, 2007. 
Holt, E.A.; Holt, M. 2004. Green Pricing Resource Guide (2nd Edition), Ed Holt \& Associates, Inc., Harpswell, Maine. Prepared for the American Wind Energy Association, Washington DC, September. http://www.awea.org/greenpower/greenPricingResourceGuide040726.pdf

Swezey, B.; Aabakken, J.; Bird, L. 2007. A Preliminary Examination of the Supply and Demand Balance for Renewable Electricity, NREL/TP-670-42266. Golden, CO: National Renewable Energy Laboratory, October. http://www.eere.energy.gov/greenpower/pdfs/42266.pdf

Swezey, B.; Bird, L. 2001. Utility Green Pricing Programs: What Defines Success? NREL/TP620-29831. Golden, CO: National Renewable Energy Laboratory, August.

http://www.eere.energy.gov/greenpower/29831.pdf

Swezey, B.; Bird, L. 2000. Green Power Marketing in the United States: A Status Report (5 ${ }^{\text {th }}$ Edition), NREL/TP-620-28738. Golden, CO: National Renewable Energy Laboratory, August. http://www.eere.energy.gov/greenpower/resources/pdfs/28738.pdf

Swezey, B.; Bird, L. 1999. Information Brief on Green Power Marketing, 4th Edition. NREL/TP-620-26901. Golden: CO: National Renewable Energy Laboratory, August. http://www.eere.energy.gov/greenpower/resources/pdfs/26901.pdf

U.S. Energy Information Administration (EIA), 2007. Renewable Energy Annual 2005, DOE/EIA, July. http://www.eia.doe.gov/cneaf/solar.renewables/page/rea_data/rea_sum.html

U.S. Energy Information Administration (EIA), 2006. Annual Energy Outlook 2006, DOE/EIA, DOE/EIA-0383(2006), February. http://www.eia.doe.gov/oiaf/aeo/index.html 


\section{Appendix A}

\section{Estimates of New Renewable Energy Capacity Serving Green Power Markets, 2000-2004}

Prior to 2005, estimates of the capacity serving green power markets were estimated based on renewable energy projects used to serve green pricing programs rather than derived from renewable energy sales. Therefore, the 2005 and 2006 capacity estimates are not directly comparable to capacity estimates from previous years. However, the two approaches yield relatively consistent results.

Bird and Swezey (2005b) provide details on the derivation of capacity estimates for years 2004 and earlier. Table A-1 presents estimates of the cumulative new renewable energy capacity serving voluntary markets from 2000 to 2004. A brief description of the methodology is included below.

Table A-1. Estimated Cumulative New Renewable Energy Capacity Supplying Green Power Markets, 2000-2004* (megawatts)

\begin{tabular}{|l|c|c|c|c|c|}
\hline Market & $\mathbf{2 0 0 0}$ & $\mathbf{2 0 0 1}$ & $\mathbf{2 0 0 2}$ & $\mathbf{2 0 0 3}$ & $\mathbf{2 0 0 4}$ \\
\hline Utility Green Pricing & $\mathbf{7 7}$ & 221 & 279 & 510 & 706 \\
\hline Competitive Markets/RECs & 90 & 542 & 695 & 1,126 & 1,528 \\
\hline Total $^{* *}$ & $\mathbf{1 6 7}$ & $\mathbf{7 6 4}$ & $\mathbf{9 7 4}$ & $\mathbf{1 , 6 3 6}$ & $\mathbf{2 , 2 3 3}$ \\
\hline
\end{tabular}

*Data not directly comparable with Table 4 .

**Totals may not add due to rounding.

Source: Bird and Swezey (2005b).

The 2004 and earlier estimates of capacity serving green power markets focus on new renewable resources used to serve green power customers. New renewable resources are defined as projects or portions of projects built specifically to serve green power customers or recently constructed projects that are used to supply green power customers and meet the regional Green-e standards ${ }^{1}$ for new renewables. The estimates do not include pre-existing renewable energy projects used for green power supply or capacity used to meet state renewables portfolio standard (RPS) requirements or other renewable energy mandates.

These estimates generally include the entire capacity of a given renewable energy project, irrespective of whether the output has been fully subscribed by green power purchasers (i.e., if a utility or developer completed a project before the entire output was sold to prospective customers). Thus, the estimates may include some capacity for which a green power buyer was not yet secured. However, in cases where a portion of a project is used to meet a renewable energy mandate, only the remainder of the project is counted. 


\section{Appendix B}

Table B-1. Top 25 Purchasers in the U.S. EPA Green Power Partnership, September 2007

\begin{tabular}{|c|c|c|c|c|c|}
\hline Rank & Organization & $\begin{array}{l}\text { Green Power } \\
\text { Usage (kWh) }\end{array}$ & $\begin{array}{l}\text { \% of Total } \\
\text { Electricity }\end{array}$ & Organization Type & Resources \\
\hline 1 & PepsiCo & $1,105,045,154$ & $100 \%$ & Food \& Beverage & Various \\
\hline 2 & Wells Fargo \& Co. & $550,000,000$ & $42 \%$ & Banking \& Fin. Services & Wind \\
\hline 3 & $\begin{array}{c}\text { Whole Foods } \\
\text { Market }\end{array}$ & $509,104,786$ & $100 \%$ & Retail & Biogas, Solar, Wind \\
\hline 4 & $\begin{array}{c}\text { The Pepsi Bottling } \\
\text { Group }\end{array}$ & $457,851,838$ & $100 \%$ & Food \& Beverage & Various \\
\hline 5 & U.S. Air Force & $457,500,000$ & $4 \%$ & Government (Federal) & $\begin{array}{l}\text { Biomass, Geothermal, } \\
\text { Solar, Wind }\end{array}$ \\
\hline 6 & $\begin{array}{l}\text { Johnson \& } \\
\text { Johnson }\end{array}$ & $400,702,978$ & $39 \%$ & Health Care & $\begin{array}{l}\text { Biomass, Small-hydro, } \\
\text { Solar, Wind }\end{array}$ \\
\hline 7 & U.S. EPA & $329,880,513$ & $100 \%$ & Government (Federal) & $\begin{array}{l}\text { Biogas, Biomass, } \\
\text { Geothermal, Wind }\end{array}$ \\
\hline 8 & \begin{tabular}{|c|} 
Kohl's Department \\
Stores \\
\end{tabular} & $201,396,000$ & $20 \%$ & Retail & Biogas, Biomass \\
\hline 9 & $\begin{array}{c}\text { Los Angeles } \\
\text { County Sanitation } \\
\text { Districts }\end{array}$ & $196,003,000$ & $57 \%$ & $\begin{array}{l}\text { Government (Local, } \\
\text { Municipal) }\end{array}$ & Biogas \\
\hline 10 & Starbucks & $185,000,000$ & $20 \%$ & $\begin{array}{l}\text { Restaurant \& Food } \\
\text { Services }\end{array}$ & Wind \\
\hline 11 & DuPont Co. & $180,000,000$ & $4 \%$ & Chemical & Biogas, Wind \\
\hline 12 & U.S. DOE & $157,964,000$ & $3 \%$ & Government (Federal) & $\begin{array}{l}\text { Biogas, Biomass, } \\
\text { Geothermal, Small- } \\
\text { hydro, Wind }\end{array}$ \\
\hline 13 & PepsiAmericas & $157,062,875$ & $100 \%$ & Food \& Beverage & Various \\
\hline 14 & Vail Resorts & $152,000,000$ & $100 \%$ & Travel \& Leisure & Wind \\
\hline 15 & Cisco Systems & $128,204,000$ & $22 \%$ & Information Technology & Various \\
\hline 16 & HSBC N.A. & $124,544,000$ & $35 \%$ & Banking \& Fin. Services & Wind \\
\hline 17 & Staples & $121,800,000$ & $20 \%$ & Retail & Biomass, Solar, Wind \\
\hline 18 & $\begin{array}{l}\text { New York } \\
\text { University }\end{array}$ & $118,616,000$ & $100 \%$ & Education (Higher) & Wind \\
\hline 19 & World Bank Group & $114,735,000$ & $100 \%$ & Non-Profit (NGO) & Wind \\
\hline 20 & $\begin{array}{c}\text { University of } \\
\text { Pennsylvania }\end{array}$ & $112,000,000$ & $29 \%$ & Education (Higher) & Wind \\
\hline 21 & IBM Corp. & $110,103,000$ & $4 \%$ & Information Technology & Wind \\
\hline 22 & $\begin{array}{l}\text { Mohawk Fine } \\
\text { Papers }\end{array}$ & $100,200,000$ & $102 \%$ & Ag. \& Nat. Resources & Wind \\
\hline 23 & $\begin{array}{c}\text { U.S. Dept. of } \\
\text { Veteran Affairs }\end{array}$ & $90,000,000$ & $3 \%$ & Government (Federal) & Biomass \\
\hline 24 & NatureWorks LLC & $89,000,000$ & $89 \%$ & Consumer Products & Wind \\
\hline 25 & Sprint Nextel & $87,600,000$ & $47 \%$ & Telecommunications & Wind \\
\hline
\end{tabular}

Source: U.S. EPA Green Power Partnership http://www.epa.gov/greenpower/partners/top25.htm 


\section{Appendix C}

Table C-1. Estimated U.S. Green Pricing Customers by State and Customer Class, 2004 and 2005

\begin{tabular}{|c|c|c|c|c|c|}
\hline \multirow[b]{3}{*}{ State } & \multirow{3}{*}{$\begin{array}{l}\text { Electric Industry } \\
\text { Participants } \\
2005^{\mathrm{a}}\end{array}$} & \multicolumn{3}{|c|}{ Participating Customers } & \multirow{3}{*}{$\begin{array}{l}2004 \\
\text { Total } \\
\end{array}$} \\
\hline & & \multicolumn{3}{|c|}{2005} & \\
\hline & & Residential & Non-residential & Total & \\
\hline Alabama & 2 & 970 & 5 & 975 & 755 \\
\hline Alaska & 1 & 320 & 5 & 325 & \\
\hline Arizona & 3 & 5,783 & 113 & 5,896 & 5,792 \\
\hline \multicolumn{6}{|l|}{ Arkansas } \\
\hline California & 9 & 38,728 & 1,708 & 40,436 & 62,090 \\
\hline Colorado & 24 & 39,387 & 1,022 & 40,409 & 40,166 \\
\hline \multicolumn{6}{|l|}{ Connecticut } \\
\hline Delaware & & & & & 15 \\
\hline District of Columbia & 2 & 4,743 & 2,306 & 7,049 & 5,222 \\
\hline Florida & 4 & 23,569 & 30 & 23,599 & 11,076 \\
\hline Georgia & 16 & 3,738 & 57 & 3,795 & 3,241 \\
\hline Hawaii & 3 & 4,234 & 45 & 4,279 & 4,005 \\
\hline Idaho & 6 & 3,764 & 114 & 3,878 & 4,283 \\
\hline Illinois & 6 & 1,225 & 2 & 1,227 & 31 \\
\hline Indiana & 10 & 1,400 & 27 & 1,427 & 1,339 \\
\hline Iowa & 54 & 7,896 & 154 & 8,050 & 7,313 \\
\hline \multicolumn{6}{|l|}{ Kansas } \\
\hline Kentucky & 10 & 796 & 13 & 809 & 513 \\
\hline \multicolumn{6}{|l|}{ Louisiana } \\
\hline Maine & 2 & 1,707 & 312 & 2,019 & 8 \\
\hline Maryland & 2 & 28,772 & 3,995 & 32,727 & 15,178 \\
\hline Massachusetts & 3 & 4,543 & 166 & 4,709 & 2,866 \\
\hline Michigan & 9 & 1,867 & 147 & 2,014 & 1,376 \\
\hline Minnesota & 93 & 24,374 & 314 & 24,688 & 23,058 \\
\hline Mississippi & 1 & 3 & 0 & 3 & 81 \\
\hline Missouri & 15 & 443 & 8 & 451 & 398 \\
\hline Montana & 6 & 392 & 8 & 400 & 407 \\
\hline Nebraska & 4 & 3,720 & 48 & 3,768 & 4,071 \\
\hline Nevada & 3 & 384 & 0 & 384 & 498 \\
\hline \multicolumn{6}{|l|}{ New Hampshire } \\
\hline New Jersey & 2 & 1,390 & 302 & 1,692 & 1,911 \\
\hline New Mexico & 11 & 9,400 & 452 & 9,852 & 8,461 \\
\hline New York & 7 & 6,192 & 385 & 6,577 & 1,485 \\
\hline North Carolina & 19 & 7,610 & 277 & 7,887 & 6,266 \\
\hline North Dakota & 12 & 6,835 & 22 & 6,857 & 4,687 \\
\hline Ohio & 3 & 360,398 & 42,035 & 402,433 & 454,509 \\
\hline Oklahoma & 7 & 10,274 & 480 & 10,754 & 9,537 \\
\hline Oregon & 11 & 62,267 & 1,488 & 63,755 & 53,902 \\
\hline Pennsylvania & 3 & 29,718 & 40 & 29,758 & 36,328 \\
\hline Rhode Island & 2 & 3,385 & 92 & 3,477 & 1,505 \\
\hline South Carolina & 10 & 2,188 & 267 & 2,455 & 2,076 \\
\hline South Dakota & 7 & 687 & 28 & 715 & 473 \\
\hline Tennessee & & & & & 6,523 \\
\hline Texas & 7 & 74,948 & 12,276 & 87,224 & 68,380 \\
\hline Utah & 5 & 16,294 & 419 & 16,713 & 14,067 \\
\hline Vermont & 1 & 2,008 & 87 & 2,095 & 899 \\
\hline Virginia & 2 & 2,989 & 20 & 3,009 & 3,438 \\
\hline Washington & 20 & 30,679 & 672 & 31,351 & 28,109 \\
\hline \multicolumn{6}{|l|}{ West Virginia } \\
\hline Wisconsin & 55 & 38,668 & 1,033 & 39,701 & 29,199 \\
\hline Wyoming & 5 & 3,086 & 64 & 3,150 & 2,796 \\
\hline Total & 442 & 871,774 & 70,998 & 942,772 & 928,333 \\
\hline
\end{tabular}

${ }^{\text {a }}$ Includes entities with green pricing programs in more than one state.

Note: Non-residential may include some customers for whom no customer class is specified. Blank cells indicate no data was reported for the state or the number of customers in a class was zero. Totals may not sum due to rounding.

Source: Energy Information Administration, Green Pricing and Net Metering Programs,2005. July 2007.

http://www.eia.doe.gov/cneaf/solar.renewables/page/greenprice/gptable63.xls 
Table C-2. Estimated U.S. Green Pricing Customers by Customer Class, 2002-2006

\begin{tabular}{l|r|r|r|}
\hline \multirow{2}{*}{ Year } & \multicolumn{3}{|c|}{ Green Pricing } \\
\cline { 2 - 4 } & Residential & $\begin{array}{c}\text { Non } \\
\text { Residential }\end{array}$ & Total \\
\hline 2002 & 688,069 & 23,481 & 711,550 \\
2003 & 819,579 & 57,547 & 877,126 \\
2004 & 864,794 & 63,539 & 928,333 \\
2005 & 871,774 & 70,998 & 942,772 \\
2006 & 609,213 & 35,954 & 645,167
\end{tabular}

Source: Energy Information Administration, Form EIA-861, "Annual Electric Power Industry Report." Electric Power Annual, 2006, October 2006 http://www.eia.doe.gov/cneaf/electricity/epa/epat7p5.html 


\section{Appendix D}

\section{Table D-1. Utilities Offering Green Pricing Programs in Regulated Markets, 2006}

\author{
Investor-Owned Utilities \\ Alabama Power Company \\ Alliant Energy \\ AmerenUE \\ Arizona Public Service \\ Avista Utilities \\ Central Vermont Public Service \\ Cheyenne Light, Fuel and Power \\ Company \\ Connecticut Light and Power \\ Consumers Energy \\ Dominion North Carolina Power \\ DTE Energy \\ Duke Energy \\ El Paso Electric Company \\ Entergy Gulf States \\ Florida Power \& Light Company \\ Georgia Power \\ Green Mountain Power \\ Gulf Power Company \\ Hawaiian Electric Company \\ Idaho Power Company \\ Indianapolis Power \& Light Company \\ Kansas City Power \& Light \\ Kentucky Utilities Company \\ Louisville Gas and Electric Company \\ Madison Gas \& Electric \\ MidAmerican Energy \\ Minnesota Power \\ Nevada Power \\ NorthWestern Energy \\ NSTAR Electric \\ OG\&E Electric Services \\ Otter Tail Power Company \\ Pacific Gas and Electric Company \\ PacifiCorp \\ Portland General Electric Company \\ Progress Energy Carolinas \\ Public Service Company of New \\ Mexico \\ Puget Sound Energy \\ Savannah Electric \\ Sierra Pacific Power Company \\ Tampa Electric Company \\ Tucson Electric Power Company \\ UniSource Energy Services \\ United Illuminating \\ Upper Peninsula Power Company \\ Vectren Energy Delivery of Indiana \\ We Energies \\ Wisconsin Public Service \\ Corporation \\ Xcel Energy
}

Electric Cooperatives

Alabama Electric Cooperative

Associated Electric Cooperative, Inc.

Bandera Electric Cooperative

Basin Electric Power Cooperative*

Boone Electric Cooperative

Buckeye Power

CCS/Soyland

Central Electric Cooperative
Central lowa Power Cooperative

Corn Belt Power Cooperatives

Dairyland Power Cooperative*

Dakota Electric Association

Delaware Electric Cooperative

Deseret Power

East Kentucky Power Cooperative*

Farmers Electric Cooperative

Georgia Electric Membership Corporation*

Golden Valley Electric Association

Great River Energy*

Gunnison County Electric Association

Holy Cross Energy

Hoosier Energy*

Intermountain Rural Electric Association

KAMO Electric Cooperative

Kauai Island Utility Cooperative (KIUC)

La Plata Electric Association

Lower Colorado River Authority

Lower Valley Energy

Midstate Electric Cooperative

Minnkota Power Cooperative*

New-Mac Electric Cooperative

Orcas Power \& Light

Oregon Trail Electric Cooperative

Park Electric Cooperative

Pedernales Electric Cooperative

Peninsula Light Company

PNGC Power*

Southern Montana Electric G\&T Cooperative

Tri-State Generation and Transmission Association*

Vigilante Electric Cooperative

Wabash Valley Power Association*

Western Farmers Electric Cooperative

Yampa Valley Electric Association

Federal

Tennessee Valley Authority*

Municipal/Public Utilities

City of Alameda

American Municipal Power-Ohio

Anaheim Public Utilities

City of Ashland

Austin Energy

Austin Utilities (MN)

Benton County Public Utility District

City of Bowling Green

Burbank Water and Power

Cedar Falls Utilities

Central Minnesota Municipal Power Agency

Chelan County Public Utility District

Clallam County PUD

Clark Public Utilities

Colorado Springs Utilities

Columbia River PUD

Concord Municipal Light Plant

Cowlitz PUD

CPS Energy (San Antonio)
Edmond Electric

City of Eldridge (IA)

ElectriCities

Emerald People's Utility District

Estes Park Light \& Power

Eugene Water \& Electric Board

Fort Collins Utilities

Gainesville Regional Utilities

Grant County PUD

Grays Harbor PUD

Heartland Consumers Power District

lowa Association of Municipal Utilities*

Keys Energy Services

Lakeland Electric

Lansing Board of Water and Light

Lenox Municipal Utilities

Lewis County PUD

Lincoln Electric System

Lodi Utilities

Longmont Power \& Communications

Los Alamos County (NM)

Los Angeles Department of Water and Power

Loveland Water \& Power

Mason County PUD No. 3

Missouri Joint Municipal Electric Utility

Missouri River Energy Services*

Moorhead Public Service

Muscatine Power and Water

City of Naperville

City of New Smyrna Beach

Northern Wasco County PUD

Oklahoma Municipal Power Authority

Omaha Public Power District

Owatonna Public Utilities

Pacific County PUD

City of Palo Alto Utilities

Pasadena Water \& Power

Platte River Power Authority*

Rochester Public Utilities (MN)

Roseville Electric

Sacramento Municipal Utility District

Salt River Project

Santee Cooper

Seattle City Light

Shrewsbury Electric and Cable Operations

Silicon Valley Power

Snohomish County Public Utility District

Southern Minnesota Municipal Power Agency $^{*}$

City Utilities of Springfield (MO)

City of St. Charles

City of St. George

Tacoma Power

City of Tallahassee

Traverse City Light \& Power

Waverly Light and Power

Wisconsin Public Power Inc.

*denotes program offered through multiple utilities or distribution cooperatives 
Table D-2. Utility/Marketer Green Power Programs in Restructured Electricity Markets, 2006

Atlantic City Electric

Consumers Energy

Connecticut Light \& Power

JP\&L

Long Island Power Authority

National Grid (Massachusetts Electric, Nantucket

Electric, Narragansett Electric, Niagara Mohawk)

NYSEG

Rochester Gas and Electric

Rockland Electric

PECO Energy

PSE\&G

United Illuminating 


\section{Appendix E}

Table E-1: Table of Utility Green Pricing Programs, September 2007

\begin{tabular}{|c|c|c|c|c|c|}
\hline State & Utility Name & $\begin{array}{l}\text { Program } \\
\text { Name }\end{array}$ & Type & $\begin{array}{l}\text { Start } \\
\text { Date }\end{array}$ & Premium \\
\hline AL & $\begin{array}{l}\text { Alabama Electric Cooperative: } \\
\text { City of Andalusia, Baldwin } \\
\text { Electric Membership } \\
\text { Cooperative, City of } \\
\text { Brundidge, Central Alabama } \\
\text { Electric Cooperative, Clarke- } \\
\text { Washington Electric } \\
\text { Membership Cooperative, } \\
\text { Coosa Valley Electric } \\
\text { Cooperative, Covington } \\
\text { Electric Cooperative, Dixie } \\
\text { Electric Cooperative, City of } \\
\text { Elba, City of Opp, Pea River } \\
\text { Electric Cooperative, Pioneer } \\
\text { Electric Cooperative, South } \\
\text { Alabama Electric Cooperative, } \\
\text { Southern Pine Electric } \\
\text { Cooperative, Tallapoosa River } \\
\text { Electric Cooperative, } \\
\text { Wiregrass Electric Cooperative }\end{array}$ & $\underline{\text { Green Power }}$ & landfill gas & 2006 & $2.0 \$ / \mathrm{kWh}$ \\
\hline$A L$ & Alabama Power Company & $\begin{array}{l}\text { Renewable Energy } \\
\text { Rate }\end{array}$ & $\begin{array}{l}\text { biomass co- } \\
\text { firing (wood) }\end{array}$ & $\begin{array}{l}2003 / \\
2000\end{array}$ & $6.0 \phi / \mathrm{kWh}$ \\
\hline AL & $\begin{array}{l}\text { TVA: City of Athens Electric } \\
\text { Department, Cullman Electric } \\
\text { Coop, Cullman Power Board, } \\
\text { Decator Utilities, Florence } \\
\text { Utilities, Hartselle Utilities, } \\
\text { Huntsville, Joe Wheeler EMC, } \\
\text { Muscle Shoals Electric Board, } \\
\text { Scottsboro Electric Power } \\
\text { Board, Sheffield Utilities, } \\
\text { Tuscumbia Electric } \\
\text { Department }\end{array}$ & $\begin{array}{l}\text { Green Power } \\
\text { Switch }\end{array}$ & $\begin{array}{l}\text { landfill gas, } \\
\text { PV, wind }\end{array}$ & 2000 & $2.67 \phi / \mathrm{kWh}$ \\
\hline AK & $\begin{array}{l}\text { Golden Valley Electric } \\
\text { Association }\end{array}$ & $\begin{array}{l}\text { Sustainable } \\
\text { Natural } \\
\text { Alternative Power } \\
\text { (SNAP) }\end{array}$ & $\begin{array}{l}\text { various local } \\
\text { projects }\end{array}$ & 2005 & Contribution \\
\hline$A Z$ & Arizona Public Service & Green Choice & $\begin{array}{l}\text { wind and } \\
\text { geothermal }\end{array}$ & 2007 & $1.0 \phi / \mathrm{kWh}$ \\
\hline$A Z$ & Salt River Project & EarthWise Energy & $\begin{array}{l}\text { central PV, } \\
\text { wind, landfill } \\
\text { gas, small } \\
\text { hydro, } \\
\text { geothermal }\end{array}$ & $1998 / 2001$ & $3.0 \$ / \mathrm{kWh}$ \\
\hline$A Z$ & $\begin{array}{l}\text { Tri-State Generation \& } \\
\text { Transmission: Columbus } \\
\text { Electric Cooperative, Inc. }\end{array}$ & $\begin{array}{l}\text { Renewable } \\
\text { Resource Power } \\
\text { Service } \\
\end{array}$ & wind, hydro & 2001 & $1.25 \$ / \mathrm{kWh}$ \\
\hline$A Z$ & $\underline{\text { Tucson Electric }}$ & GreenWatts & $\begin{array}{l}\text { landfill gas, } \\
\text { PV }\end{array}$ & 2000 & $10 \phi / k W h$ \\
\hline$A Z$ & UniSource Energy Services & GreenWatts & PV & 2004 & $10 \phi / \mathrm{kWh}$ \\
\hline
\end{tabular}




\begin{tabular}{|c|c|c|c|c|c|}
\hline State & Utility Name & $\begin{array}{l}\text { Program } \\
\text { Name }\end{array}$ & Type & $\begin{array}{l}\text { Start } \\
\text { Date }\end{array}$ & Premium \\
\hline CA & Anaheim Public Utilities & $\begin{array}{l}\text { Green Power for } \\
\text { the Grid }\end{array}$ & $\begin{array}{l}\text { wind, landfill } \\
\text { gas }\end{array}$ & 2002 & $1.5 \phi / \mathrm{kWh}$ \\
\hline CA & Anaheim Public Utilities & $\begin{array}{l}\text { Sun Power for the } \\
\text { Schools }\end{array}$ & PV & 2002 & Contribution \\
\hline CA & Burbank Water and Power & \begin{tabular}{|l|} 
Green Energy \\
Champion \\
\end{tabular} & various & 2007 & $2.0 \$ / \mathrm{kWh}$ \\
\hline CA & $\begin{array}{l}\text { Los Angeles Department of } \\
\text { Water and Power }\end{array}$ & $\begin{array}{l}\text { Green Power for a } \\
\text { Green LA }\end{array}$ & $\begin{array}{l}\text { wind, landfill } \\
\text { gas }\end{array}$ & 1999 & $3.0 \$ / \mathrm{kWh}$ \\
\hline CA & PacifiCorp: Pacific Power & Blue Sky Block & wind & 2000 & $1.95 \phi / \mathrm{kWh}$ \\
\hline CA & Palo Alto Utilities/3 Degrees & Palo Alto Green & wind, PV & $\begin{array}{l}2003 / \\
2000\end{array}$ & $1.5 \$ / \mathrm{kWh}$ \\
\hline CA & Pasadena Water \& Power & Green Power & wind & 2003 & $2.5 \phi / \mathrm{kWh}$ \\
\hline CA & Roseville Electric/3Degrees & Green Roseville & wind, PV & 2005 & $1.5 \$ / \mathrm{kWh}$ \\
\hline CA & $\begin{array}{l}\text { Sacramento Municipal Utility } \\
\text { District }\end{array}$ & Greenergy & $\begin{array}{l}\text { wind, landfill } \\
\text { gas, hydro, } \\
\text { PV }\end{array}$ & 1997 & $\begin{array}{l}1.0 \$ / \mathrm{kWh} \text { or } \\
\$ 6 / \mathrm{month}\end{array}$ \\
\hline CA & $\begin{array}{l}\text { Silicon Valley Power / } 3 \\
\text { Degrees }\end{array}$ & $\begin{array}{l}\text { Santa Clara Green } \\
\text { Power }\end{array}$ & wind, PV & 2004 & $1.5 \phi / \mathrm{kWh}$ \\
\hline $\mathrm{CO}$ & Colorado Springs Utilities & Green Power & wind & 1999 & $3.0 \$ / \mathrm{kWh}$ \\
\hline $\mathrm{CO}$ & Holy Cross Energy & $\begin{array}{l}\text { Wind Power } \\
\text { Pioneers }\end{array}$ & wind & 1998 & $1.5 \phi / \mathrm{kWh}$ \\
\hline $\mathrm{CO}$ & Holy Cross Energy & $\begin{array}{l}\text { Local Renewable } \\
\text { Energy Pool }\end{array}$ & $\begin{array}{l}\text { small hydro, } \\
\text { PV }\end{array}$ & 2002 & $2.33 \phi / k W h$ \\
\hline $\mathrm{CO}$ & $\begin{array}{l}\text { Intermountain Rural Electric } \\
\text { Association / Sterling Planet }\end{array}$ & National Wind & wind & 2006 & $1.0 \$ / \mathrm{kWh}$ \\
\hline $\mathrm{CO}$ & $\begin{array}{l}\text { Intermountain Rural Electric } \\
\text { Association / Sterling Planet }\end{array}$ & National Solar & solar & 2006 & $5.5 \phi / \mathrm{kWh}$ \\
\hline $\mathrm{CO}$ & $\begin{array}{l}\text { Platte River Power Authority: } \\
\text { Estes Park, Fort Collins } \\
\text { Utilities, Longmont Power \& } \\
\text { Communications, Loveland } \\
\text { Water \& Power }\end{array}$ & $\begin{array}{l}\text { Wind Energy } \\
\text { Premium }\end{array}$ & wind & 1999 & $\begin{array}{l}1.0 \phi / \mathrm{kWh}- \\
2.5 \phi / \mathrm{kWh}\end{array}$ \\
\hline
\end{tabular}




\begin{tabular}{|c|c|c|c|c|c|}
\hline State & Utility Name & $\begin{array}{l}\text { Program } \\
\text { Name }\end{array}$ & Type & $\begin{array}{l}\text { Start } \\
\text { Date }\end{array}$ & Premium \\
\hline $\mathrm{CO}$ & $\begin{array}{l}\text { Tri-State Generation \& } \\
\text { Transmission : Delta- } \\
\text { Montrose Electric Association, } \\
\text { Empire Electric Association, } \\
\text { Inc., Gunnison County Electric } \\
\text { Association, Inc., Highline } \\
\text { Electric Association, La Plata } \\
\text { Electric Association, Inc., } \\
\text { Morgan County Rural Electric } \\
\text { Association, Mountain Parks } \\
\text { Electric, Inc., Mountain View } \\
\text { Electric Association, Inc., } \\
\text { Poudre Valley Rural Electric } \\
\text { Association, Inc., San Isabel } \\
\text { Electric Association, Inc., San } \\
\text { Luis Valley Rural Electric } \\
\text { Cooperative, Inc., San Miguel } \\
\text { Power Association, Inc., } \\
\text { Sangre de Cristo Electric } \\
\text { Association, Inc., Southeast } \\
\text { Colorado Power Association, } \\
\text { United Power, Inc., White } \\
\text { River Electric Association, } \\
\text { Inc., Y-W Electric Association, } \\
\text { Inc. } \\
\end{array}$ & $\begin{array}{l}\frac{\text { Renewable }}{\text { Resource Power }} \\
\text { Service } \\
\\
\end{array}$ & wind, hydro & 1998 & $1.25 \phi / \mathrm{kWh}$ \\
\hline $\mathrm{CO}$ & Xcel Energy & $\begin{array}{l}\text { Renewable Energy } \\
\text { Trust }\end{array}$ & PV & 1993 & Contribution \\
\hline $\mathrm{CO}$ & Xcel Energy & WindSource & wind & 1997 & $-0.67 \phi / k W h$ \\
\hline $\mathrm{CO}$ & $\begin{array}{l}\text { Yampa Valley Electric } \\
\text { Association }\end{array}$ & $\begin{array}{l}\text { Wind Energy } \\
\text { Program }\end{array}$ & wind & 1999 & $3.0 \$ / \mathrm{kWh}$ \\
\hline DE & Delaware Electric Cooperative & $\begin{array}{l}\text { Renewable Energy } \\
\text { Rider }\end{array}$ & landfill gas & 2006 & $0.2 \phi / \mathrm{kWh}$ \\
\hline $\mathrm{FL}$ & $\begin{array}{l}\text { Alabama Electric Cooperative: } \\
\text { CHELCO, Escambia River } \\
\text { Electric Cooperative, Gulf } \\
\text { Coast Electric Cooperative, } \\
\text { West Florida Electric } \\
\text { Cooperative } \\
\end{array}$ & Green Power & landfill gas & 2006 & $2.0 \$ / \mathrm{kWh}$ \\
\hline FL & $\begin{array}{l}\text { City of Tallahassee/Sterling } \\
\text { Planet }\end{array}$ & Green for You & PV only & 2002 & $11.6 \$ / \mathrm{kWh}$ \\
\hline $\mathrm{FL}$ & $\begin{array}{l}\text { City of Tallahassee/Sterling } \\
\text { Planet }\end{array}$ & Green for You & biomass, PV & 2002 & $1.6 \$ / \mathrm{kWh}$ \\
\hline $\mathrm{FL}$ & $\begin{array}{l}\text { Florida Power \& Light / Green } \\
\text { Mountain Energy }\end{array}$ & Sunshine Energy & $\begin{array}{l}\text { biomass, } \\
\text { wind, PV }\end{array}$ & 2004 & $0.975 \phi / k W h$ \\
\hline $\mathrm{FL}$ & Gainesville Regional Utilities & GRUgreen Energy & $\begin{array}{l}\text { landfill gas, } \\
\text { wind, PV }\end{array}$ & 2003 & $2.0 \phi / \mathrm{kWh}$ \\
\hline $\mathrm{FL}$ & $\begin{array}{l}\text { Keys Energy Services / } \\
\text { Sterling Planet }\end{array}$ & $\begin{array}{l}\text { GO GREEN: USA } \\
\text { Green }\end{array}$ & $\begin{array}{l}\text { wind, } \\
\text { biomass,PV }\end{array}$ & 2004 & $1.60 \$ / \mathrm{kWh}$ \\
\hline $\mathrm{FL}$ & $\begin{array}{l}\text { Keys Energy Services / } \\
\text { Sterling Planet }\end{array}$ & $\begin{array}{l}\text { GO GREEN: } \\
\text { Florida Ever } \\
\text { Green }\end{array}$ & $\begin{array}{l}\text { solar hot } \\
\text { water, PV, } \\
\text { biomass }\end{array}$ & 2004 & $2.75 \phi / k W h$ \\
\hline FL & $\frac{\text { Tampa Electric Company }}{(\text { TECO })}$ & $\begin{array}{l}\text { Renewable Energy } \\
\text { Program }\end{array}$ & $\begin{array}{l}\text { PV, landfill, } \\
\text { biomass co- } \\
\text { firing (wood) }\end{array}$ & 2000 & $2.5 \phi / \mathrm{kWh}$ \\
\hline
\end{tabular}




\begin{tabular}{|c|c|c|c|c|c|}
\hline State & Utility Name & $\begin{array}{c}\text { Program } \\
\text { Name }\end{array}$ & Type & $\begin{array}{l}\text { Start } \\
\text { Date }\end{array}$ & Premium \\
\hline FL & $\begin{array}{l}\text { Utilities Commission City of } \\
\text { New Smyrna Beach }\end{array}$ & Green Fund & $\begin{array}{l}\text { local PV } \\
\text { projects }\end{array}$ & 1999 & Contribution \\
\hline GA & $\begin{array}{l}\text { Georgia Electric Membership } \\
\text { Corporation (35 of } 42 \text { coops } \\
\text { offer program): Altamaha } \\
\text { EMC, Amicalola EMC, } \\
\text { Canoochee EMC, Carroll EMC, } \\
\text { Central Georgia EMC, Cobb } \\
\text { EMC, Coastal Electric, Colquitt } \\
\text { EMC, Coweta-Fayette EMC, } \\
\text { Diverse Power, Flint Energies, } \\
\text { Grady EMC, GreyStone Power, } \\
\text { Habersham EMC, Hart EMC } \\
\text { Irwin EMC, Jackson EMC, } \\
\text { Jefferson Energy, Little } \\
\text { Ocmulgee EMC, Middle } \\
\text { Georgia EMC, Mitchell EMC, } \\
\text { Ocmulgee EMC, Oconee EMC, } \\
\text { Planters EMC, Rayle EMC, } \\
\text { Sawnee EMC, Slash Pine EMC, } \\
\text { Snapping Shoals EMC, } \\
\text { Southern Rivers Energy, } \\
\text { Sumter EMC, Three Notch } \\
\text { EMC, Tri-County EMC, Upson } \\
\text { EMC, Walton EMC } \\
\text { Washington EMC } \\
\text { Wash }\end{array}$ & Green Power EMC & $\begin{array}{l}\text { landfill gas, } \\
\text { PV in schools }\end{array}$ & 2001 & $\begin{array}{l}2.0 \phi / \mathrm{kWh}- \\
3.3 \phi / \mathrm{kWh}\end{array}$ \\
\hline GA & Georgia Power & Green Energy & landfill gas & 2006 & $4.5 \phi / \mathrm{kWh}$ \\
\hline GA & $\begin{array}{l}\text { TVA: Blue Ridge Mountain } \\
\text { Electric Membership } \\
\text { Corporation, North Georgia } \\
\text { Electric Membership } \\
\text { Corporation }\end{array}$ & $\begin{array}{l}\text { Green Power } \\
\text { Switch }\end{array}$ & $\begin{array}{l}\text { landfill gas, } \\
\text { PV, wind }\end{array}$ & 2000 & $2.67 \phi / k W h$ \\
\hline $\mathrm{HI}$ & Hawaiian Electric & $\begin{array}{l}\text { Sun Power for } \\
\text { Schools }\end{array}$ & PV in schools & 1997 & Contribution \\
\hline HI & $\begin{array}{l}\text { Kauai Island Utility } \\
\text { Cooperative }\end{array}$ & Green Rate & $\begin{array}{l}\text { distributed } \\
\text { renewable } \\
\text { energy } \\
\text { systems }\end{array}$ & TBD & TBD \\
\hline ID & Avista Utilities & Buck-A-Block & wind & 2002 & $0.33 \phi / \mathrm{kWh}$ \\
\hline ID & Idaho Power & $\begin{array}{l}\text { Green Power } \\
\text { Program } \\
\end{array}$ & various & 2001 & $0.98 \phi / k W h$ \\
\hline ID & PacifiCorp: Utah Power & Blue Sky & wind & 2003 & $1.95 \$ / \mathrm{kWh}$ \\
\hline ID & Vigilante Electric Cooperative & $\begin{array}{l}\text { Alternative } \\
\text { Renewable Energy } \\
\text { Program }\end{array}$ & wind & 2003 & $1.1 \phi / k W h$ \\
\hline IL & $\begin{array}{l}\text { CCS/Soyland and Community } \\
\text { Energy, Inc. (8 of } 11 \text { coops } \\
\text { offer program): Adams } \\
\text { Electric Co-op, Coles-Moultrie } \\
\text { Electric, Eastern Illini Electric, } \\
\text { McDonough Power, Menard, } \\
\text { Rural Electric Convenience } \\
\text { Co-op, Shelby Electric, Spoon } \\
\text { River Electric Co-op }\end{array}$ & EcoEnergy & wind & 2005 & $3.0 \phi / \mathrm{kWh}$ \\
\hline
\end{tabular}




\begin{tabular}{|c|c|c|c|c|c|}
\hline State & Utility Name & $\begin{array}{c}\text { Program } \\
\text { Name }\end{array}$ & Type & $\begin{array}{l}\text { Start } \\
\text { Date }\end{array}$ & Premium \\
\hline IL & $\begin{array}{l}\text { City of Naperville / } \\
\text { Community Energy }\end{array}$ & Renewable Energy & $\begin{array}{l}\text { wind, small } \\
\text { hydro, PV }\end{array}$ & 2005 & $2.5 \$ / \mathrm{kWh}$ \\
\hline IL & $\begin{array}{l}\text { City of St. Charles/ComEd and } \\
\text { Community Energy, Inc. }\end{array}$ & $\underline{T B D}$ & $\begin{array}{l}\text { wind, landfill } \\
\text { gas }\end{array}$ & 2003 & Contribution \\
\hline IL & $\begin{array}{l}\text { Dairyland Power Cooperative: } \\
\text { Jo-Carroll Energy/Elizabeth }\end{array}$ & $\begin{array}{l}\text { Evergreen } \\
\text { Renewable Energy } \\
\text { Program }\end{array}$ & $\begin{array}{l}\text { landfill gas, } \\
\text { biogas, } \\
\text { hydro, wind }\end{array}$ & 1997 & $1.5 \phi / \mathrm{kWh}$ \\
\hline IN & Duke Energy & GoGreen Power & $\begin{array}{l}\text { wind, PV, } \\
\text { landfill gas, } \\
\text { digester gas }\end{array}$ & 2001 & $2.5 \phi / \mathrm{kWh}$ \\
\hline IN & $\begin{array}{l}\text { Hoosier Energy ( } 5 \text { of } 17 \text { coops } \\
\text { offer program): Southeastern } \\
\text { Indiana REMC, South Central } \\
\text { Indiana REMC, Utilities District } \\
\text { of Western Indiana REMC, } \\
\text { Decatur County REMC, } \\
\text { Daviess-Martin County REMC } \\
\end{array}$ & EnviroWatts & landfill gas & 2001 & $\begin{array}{l}2.0 \$ / \mathrm{kWh}- \\
4.0 \$ / \mathrm{kWh}\end{array}$ \\
\hline IN & Indianapolis Power \& Light & $\begin{array}{l}\text { Green Power } \\
\text { Option }\end{array}$ & wind & 1998 & $0.35 \$ / k W h$ \\
\hline IN & $\begin{array}{l}\text { Wabash Valley Power } \\
\text { Association (7 of } 27 \text { coops } \\
\text { offer program): Boone REMC, } \\
\text { Hendricks Power Cooperative } \\
\text { Kankakee Valley REMC } \\
\text { Miami-Cass REMC, Tipmont } \\
\text { REMC, White County REMC } \\
\text { Northeastern REMC } \\
\end{array}$ & EnviroWatts & landfill gas & 2000 & $\begin{array}{l}0.9 \$ / \mathrm{kWh}- \\
1.0 \$ / \mathrm{kWh}\end{array}$ \\
\hline IA & Alliant Energy & $\underline{\text { Second Nature }}$ & $\begin{array}{l}\text { landfill gas, } \\
\text { wind }\end{array}$ & 2001 & $2.0 \phi / \mathrm{kWh}$ \\
\hline IA & $\begin{array}{l}\text { Associated Electric } \\
\text { Cooperative, Inc.: Access } \\
\text { Energy Cooperative, Chariton } \\
\text { Valley Electric Cooperative, } \\
\text { Southern Iowa Electric } \\
\text { Cooperative }\end{array}$ & varies by utility & $\begin{array}{l}\text { biomass, } \\
\text { wind }\end{array}$ & 2003 & $\begin{array}{l}2.0 \$ / \mathrm{kWh}- \\
3.5 \$ / \mathrm{kWh}\end{array}$ \\
\hline IA & $\begin{array}{l}\text { Basin Electric Power } \\
\text { Cooperative: Lyon Rural, } \\
\text { Harrison County, Nishnabotna } \\
\text { Valley Cooperative, Northwest } \\
\text { Rural Electric Cooperative } \\
\text { Western Iowa } \\
\end{array}$ & Prairie Winds & wind & 2000 & $0.5 \$ / \mathrm{kWh}$ \\
\hline IA & Cedar Falls Utilities & Harvest the Wind & wind & 2000 & $2.5 \$ / \mathrm{kWh}$ \\
\hline
\end{tabular}




\begin{tabular}{|c|c|c|c|c|c|}
\hline State & Utility Name & $\begin{array}{c}\text { Program } \\
\text { Name }\end{array}$ & Type & $\begin{array}{l}\text { Start } \\
\text { Date }\end{array}$ & Premium \\
\hline IA & \begin{tabular}{|l} 
Central Iowa Power \\
Cooperatives (all 12 coops 11 \\
muni): Maquoketa Valley \\
Electric Cooperative, Eastern \\
Iowa REC, East-Central Iowa \\
REC, Linn County REC, Pella, \\
TIP Rural Electric Cooperative \\
Clarke Electric Cooperative \\
Midland Power Cooperative, \\
Guthrie County REC, Farmers \\
Electric Cooperative \\
Southwest Iowa REC, \\
Consumer Energy, South \\
Iowa Municipal Electric \\
Cooperative Association \\
\end{tabular} & Wind Power & wind & 2006 & $\begin{array}{l}1.5 \phi / \mathrm{kWh}- \\
2.5 \phi / \mathrm{kWh}\end{array}$ \\
\hline IA & $\begin{array}{l}\text { Corn Belt Power Cooperatives } \\
\text { (5 of } 11 \text { coops offer } \\
\text { program): Butler County REC, } \\
\text { Franklin REC, Grundy County } \\
\text { REC, Humboldt County REC, } \\
\text { Sac County REC }\end{array}$ & $\begin{array}{l}\text { Energy Wise } \\
\text { Renewables }\end{array}$ & wind & 2003 & $1.5 \$ / \mathrm{kWh}$ \\
\hline IA & $\begin{array}{l}\text { Dairyland Power Cooperative: } \\
\text { Allamakee-Clayton/Postville, } \\
\text { Hawkeye Tri-County/Cresco, } \\
\text { Heartland Power/Thompson \& } \\
\text { St. Ansgar } \\
\end{array}$ & $\begin{array}{l}\text { Evergreen } \\
\text { Renewable Energy } \\
\text { Program }\end{array}$ & $\begin{array}{l}\text { hydro, wind, } \\
\text { landfill gas, } \\
\text { biogas }\end{array}$ & 1998 & $3.0 \phi / \mathrm{kWh}$ \\
\hline IA & Farmers Electric Cooperative & $\begin{array}{l}\text { Green Power } \\
\text { Project }\end{array}$ & $\begin{array}{l}\text { biodiesel, } \\
\text { wind }\end{array}$ & 2004 & Contribution \\
\hline
\end{tabular}




\begin{tabular}{|c|c|c|c|c|c|}
\hline State & Utility Name & $\begin{array}{c}\text { Program } \\
\text { Name }\end{array}$ & Type & $\begin{array}{l}\text { Start } \\
\text { Date }\end{array}$ & Premium \\
\hline IA & $\begin{array}{l}\text { Iowa Association of Municipal } \\
\text { Utilities (84 of 137 munis } \\
\text { offer program) Afton, Algona, } \\
\text { Alta Vista, Aplington, Auburn, } \\
\text { Bancroft, Bellevue, } \\
\text { Bloomfield, Breda, Brooklyn, } \\
\text { Buffalo, Burt, Callender, } \\
\text { Carlisle, Cascade, Coggon, } \\
\text { Coon Rapids, Corning, } \\
\text { Corwith, Danville, Dayton, } \\
\text { Durant, Dysart, Earlville, } \\
\text { Eldridge, Ellsworth, } \\
\text { Estherville, Fairbank, } \\
\text { Farnhamville, Fontanelle, } \\
\text { Forest City, Gowrie, Grafton, } \\
\text { Grand Junction, Greenfield, } \\
\text { Grundy Center, Guttenberg, } \\
\text { Hopkinton, Hudson, } \\
\text { Independence, Keosauqua, La } \\
\text { Porte City, Lake Mills, Lake } \\
\text { View, Laurens, Lenox, } \\
\text { Livermore, Maquoketa, } \\
\text { Marathon, McGregor, Milford, } \\
\text { Montezuma, Mount Pleasant, } \\
\text { Neola, New Hampton, Ogden, } \\
\text { Orient, Osage, Panora, Pella, } \\
\text { Pocahontas, Preston, Readlyn, } \\
\text { Rockford, Sabula, Sergeant } \\
\text { Bluff, Sibley, Spencer, } \\
\text { Stanhope, State Center, } \\
\text { Stratford, Strawberry Point, } \\
\text { Stuart, Tipton, Villisca, } \\
\text { Vinton, Webster City, West } \\
\text { Bend, West Liberty, West } \\
\text { Point, Westfield, Whittemore, } \\
\text { Wilton, Winterset } \\
\end{array}$ & Green City Energy & $\begin{array}{l}\text { wind, } \\
\text { biomass, PV }\end{array}$ & 2003 & Varies by utility \\
\hline IA & MidAmerican Energy & $\begin{array}{l}\text { Renewable } \\
\text { Advantage }\end{array}$ & wind & 2004 & Contribution \\
\hline IA & $\begin{array}{l}\text { Missouri River Energy } \\
\text { Services: Alton, Atlantic, } \\
\text { Denison, Fontanelle, Hartley, } \\
\text { Hawarden, Kimballton, Lake } \\
\text { Park, Manilla, Orange City, } \\
\text { Paullina, Primghar, Remsen, } \\
\text { Rock Rapids, Sanborn, } \\
\text { Shelby, Sioux Center, } \\
\text { Woodbine }\end{array}$ & $\underline{\text { RiverWinds }}$ & wind & 2003 & $\begin{array}{l}2.0 \$ / \mathrm{kWh}- \\
2.5 \phi / \mathrm{kWh}\end{array}$ \\
\hline IA & Muscatine Power and Water & Solar Muscatine & PV & 2004 & Contribution \\
\hline IA & Waverly Light \& Power & $\begin{array}{l}\text { Green Power } \\
\text { Choice }\end{array}$ & wind & 2003 & Contribution \\
\hline IA & Waverly Light \& Power & Iowa Energy Tags & wind & 2001 & $2.0 \$ / \mathrm{kWh}$ \\
\hline
\end{tabular}




\begin{tabular}{|c|c|c|c|c|c|}
\hline State & Utility Name & $\begin{array}{l}\text { Program } \\
\text { Name }\end{array}$ & Type & $\begin{array}{l}\text { Start } \\
\text { Date }\end{array}$ & Premium \\
\hline KY & $\begin{array}{l}\text { East Kentucky Power } \\
\text { Cooperative: Blue Grass } \\
\text { Energy, Clark, Cumberland, } \\
\text { Fleming-Mason, Grayson, } \\
\text { Inter-County Energy, Jackson, } \\
\text { Licking Valley, Nolin, Owen } \\
\text { Electric, Salt River, Shelby, } \\
\text { South Kentucky }\end{array}$ & EnviroWatts & landfill gas & 2002 & $2.75 \phi / k W h$ \\
\hline KY & $\begin{array}{l}\text { E.ON U.S.: Louisville Gas and } \\
\text { Electric Co., Kentucky Utilities } \\
\text { Co. }\end{array}$ & Green Energy & $\begin{array}{l}100 \% \text { low } \\
\text { impact hydro }\end{array}$ & 2007 & $\begin{array}{l}1.67 \$ / \mathrm{kWh} \\
\text { residential, } \\
1.3 \phi / \mathrm{kWh} \\
\text { commercial }\end{array}$ \\
\hline KY & $\begin{array}{l}\text { TVA: Bowling Green Municipal } \\
\text { Utilities, Franklin Electric Plant } \\
\text { Board }\end{array}$ & Green Power & $\begin{array}{l}\text { landfill gas, } \\
\text { PV, wind }\end{array}$ & 2000 & $2.67 \phi / \mathrm{kWh}$ \\
\hline LA & Entergy Gulf States & $\begin{array}{l}\text { Green Pricing } \\
\text { Program }\end{array}$ & biomass & 2007 & $2.5 \phi / \mathrm{kWh}$ \\
\hline MA & $\begin{array}{l}\text { Concord Municipal Light Plant } \\
\text { (CMLP) }\end{array}$ & Green Power & hydro & 2004 & $3.0 \$ / \mathrm{kWh}$ \\
\hline MA & $\begin{array}{l}\text { Shrewsbury Electric and Cable } \\
\text { Operations }\end{array}$ & SELCO GreenLight & wind & 2007 & $6.67 \phi / k W h$ \\
\hline MI & Consumers Energy & Green Generation & $\begin{array}{l}68 \% \text { wind, } \\
32 \% \text { landfill } \\
\text { gas }\end{array}$ & 2005 & $1.67 \phi / \mathrm{kWh}$ \\
\hline MI & DTE Energy & GreenCurrents & wind & 2007 & $\begin{array}{l}2.0 \$ / \mathrm{kWh}- \\
2.5 \phi / \mathrm{kWh}\end{array}$ \\
\hline MI & $\begin{array}{l}\text { Lansing Board of Water and } \\
\text { Light }\end{array}$ & $\begin{array}{l}\text { GreenWise } \\
\text { Electric Power } \\
\end{array}$ & $\begin{array}{l}\text { landfill gas, } \\
\text { small hydro }\end{array}$ & 2001 & $3.0 \$ / \mathrm{kWh}$ \\
\hline MI & Traverse City Light and Power & Green Rate & wind & 1996 & $2.0 \phi / \mathrm{kWh}$ \\
\hline MI & $\begin{array}{l}\text { Upper Peninsula Power } \\
\text { Company }\end{array}$ & NatureWise & $\begin{array}{l}\text { wind, landfill } \\
\text { gas and } \\
\text { animal waste } \\
\text { methane }\end{array}$ & 2004 & $4.0 \$ / \mathrm{kWh}$ \\
\hline MI & We Energies & $\begin{array}{l}\text { Energy for } \\
\text { Tomorrow } \\
\end{array}$ & $\begin{array}{l}\text { wind, landfill } \\
\text { gas, hydro }\end{array}$ & 2000 & $2.04 థ / \mathrm{kWh}$ \\
\hline MN & Alliant Energy & Second Nature & $\begin{array}{l}\text { landfill gas, } \\
\text { wind }\end{array}$ & 2002 & $2.0 \$ / \mathrm{kWh}$ \\
\hline MN & $\begin{array}{l}\text { Austin Utilities, Owatonna } \\
\text { Public Utilities, Rochester } \\
\text { Public Utilities } \\
\end{array}$ & SolarChoice & $\begin{array}{l}\text { local PV } \\
\text { systems }\end{array}$ & 2006 & Contribution \\
\hline MN & $\begin{array}{l}\text { Basin Electric Power } \\
\text { Cooperative: Minnesota Valley } \\
\text { Electric Coop, Sioux Valley } \\
\text { Southwestern }\end{array}$ & Prairie Winds & wind & 2002 & $0.5 \$ / \mathrm{kWh}$ \\
\hline MN & $\begin{array}{l}\text { Central Minnesota Municipal } \\
\text { Power Agency: Blue Earth, } \\
\text { Delano, Glencoe, Granite } \\
\text { Falls, Janesville, Kenyon, Lake } \\
\text { Crystal, Madelia, Mt. Lake, } \\
\text { New Ulm, Sleepy Eye } \\
\text { Springfield, Truman, and } \\
\text { Windom } \\
\end{array}$ & $\begin{array}{l}\text { Green Energy } \\
\text { Program } \\
\end{array}$ & $\begin{array}{l}\text { wind, landfill } \\
\text { gas }\end{array}$ & 2000 & $\begin{array}{l}1.5 \phi / \mathrm{kWh}- \\
2.5 \$ / \mathrm{kWh}\end{array}$ \\
\hline
\end{tabular}




\begin{tabular}{|c|c|c|c|c|c|}
\hline State & Utility Name & $\begin{array}{c}\text { Program } \\
\text { Name }\end{array}$ & Type & $\begin{array}{l}\text { Start } \\
\text { Date }\end{array}$ & Premium \\
\hline MN & $\begin{array}{l}\text { Dairyland Power Cooperative: } \\
\text { Freeborn-Mower Cooperative / } \\
\text { Albert Lea, People's / } \\
\text { Rochester, Tri-County / } \\
\text { Rushford }\end{array}$ & \begin{tabular}{|l}
$\frac{\text { Evergreen }}{\text { Renewable Energy }}$ \\
Program
\end{tabular} & $\begin{array}{l}\text { hydro, wind, } \\
\text { landfill gas, } \\
\text { biogas }\end{array}$ & 1998 & $1.5 \$ / \mathrm{kWh}$ \\
\hline MN & 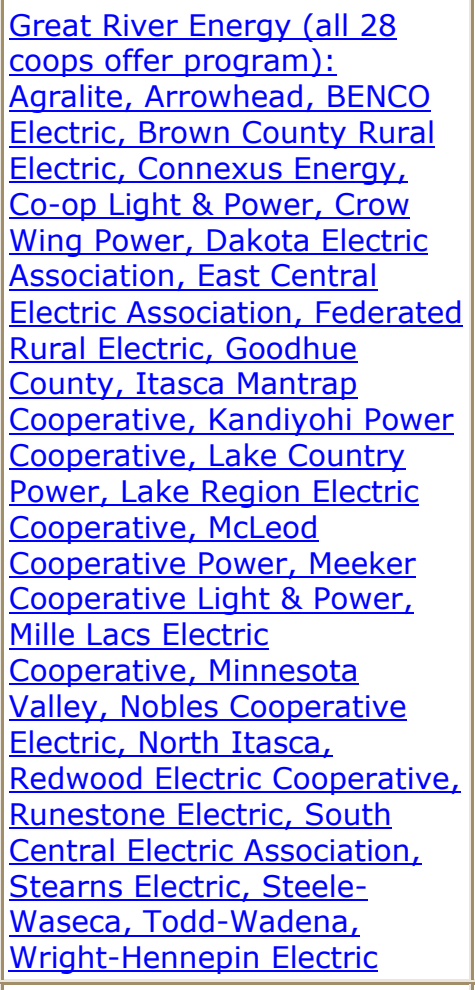 & \begin{tabular}{|l}
$\frac{\text { Wellspring }}{\text { Renewable Wind }}$ \\
Energy Program \\
\\
\end{tabular} & wind & 1998 & $\begin{array}{l}1.55 \$ / \mathrm{kWh}- \\
2.0 \phi / \mathrm{kWh}\end{array}$ \\
\hline MN & Minnesota Power & WindSense & wind & 2002 & $2.5 \phi / \mathrm{kWh}$ \\
\hline MN & $\begin{array}{l}\text { Minnkota Power Cooperative: } \\
\text { Beltrami, Clearwater Polk } \\
\text { North Star, PKM, Red Lake } \\
\text { Red River, Roseau, Wild Rice; } \\
\text { Northern Municipal Power } \\
\text { Agency (10 municipals) }\end{array}$ & $\begin{array}{l}\text { Infinity Wind } \\
\text { Energy }\end{array}$ & wind & 1999 & $0.5 \phi / \mathrm{kWh}$ \\
\hline MN & $\begin{array}{l}\text { Missouri River Energy } \\
\text { Services: Adrian, Alexandria, } \\
\text { Barnesville, Benson, } \\
\text { Breckenridge, Detroit Lakes, } \\
\text { Elbow Lake, Henning, } \\
\text { Elbackson, Lakefield, Lake Park, } \\
\text { Luverne, Madison, Moorhead, } \\
\text { Lrtonville, St. James, Sauk } \\
\text { Centre, Staples, Wadena, } \\
\text { Westbrook, Worthington } \\
\end{array}$ & RiverWinds & wind & 2002 & $\begin{array}{l}2.0 \$ / \mathrm{kWh}- \\
2.5 \$ / \mathrm{kWh}\end{array}$ \\
\hline MN & Moorhead Public Service & Capture the Wind & wind & 1998 & $1.5 \$ / \mathrm{kWh}$ \\
\hline MN & Otter Tail Power Company & TailWinds & wind & 2002 & $1.6 \$ / \mathrm{kWh}$ \\
\hline
\end{tabular}




\begin{tabular}{|c|c|c|c|c|c|}
\hline State & Utility Name & $\begin{array}{c}\text { Program } \\
\text { Name }\end{array}$ & Type & $\begin{array}{l}\text { Start } \\
\text { Date }\end{array}$ & Premium \\
\hline MN & $\begin{array}{l}\text { Southern Minnesota Municipal } \\
\text { Power Agency (all } 18 \text { munis } \\
\text { offer program): Fairmont } \\
\text { Public Utilities, Wells Public } \\
\text { Utilities, Austin Utilities, } \\
\text { Preston Public Utilities, Spring } \\
\text { Valley Utilities, Blooming } \\
\text { Prairie Public Utilities, } \\
\text { Rochester Public Utilities, } \\
\text { Owatonna Public Utilities, } \\
\text { Waseca Utilities, St. Peter } \\
\text { Municipal Utilities, Lake City } \\
\text { Utilities, New Prague Utilities } \\
\text { Commission, Redwood Falls } \\
\text { Public Utilities, Litchfield } \\
\text { Public Utilities, Princeton } \\
\text { Public Utilities, North Branch } \\
\text { Water and Light, Mora } \\
\text { Municipal Utilities, Grand } \\
\text { Marais Public Utilities } \\
\end{array}$ & $\begin{array}{l}\text { SMMPA Wind } \\
\text { Power }\end{array}$ & wind & 2000 & $1.0 \phi / \mathrm{kWh}$ \\
\hline MN & Xcel Energy & WindSource & wind & 2003 & $2.0 థ / \mathrm{kWh}$ \\
\hline MS & $\begin{array}{l}\text { TVA: City of Oxford, North } \\
\text { East Mississippi Electric Power } \\
\text { Asssociation, Starkville } \\
\text { Electric System } \\
\end{array}$ & $\begin{array}{l}\text { Green Power } \\
\text { Switch }\end{array}$ & $\begin{array}{l}\text { landfill gas, } \\
\text { PV, wind }\end{array}$ & 2000 & $2.67 \phi / k W h$ \\
\hline MO & AmerenUE/3Degrees & Pure Power & $\begin{array}{l}75 \% \text { wind, } \\
25 \% \text { other } \\
\text { renewables }\end{array}$ & 2007 & $1.5 \$ / \mathrm{kWh}$ \\
\hline MO & \begin{tabular}{|l} 
Associated Electric \\
Cooperative, Inc.: Black River \\
Electric Cooperative, Boone \\
Electric Cooperative, Callaway \\
Electric Cooperative, Co-Mo \\
Electric Cooperative, \\
Crawford Electric Cooperative, \\
Cuivre River Electric \\
Cooperative, Howell-Oregon \\
Electric Cooperative, \\
Intercounty Electric \\
Cooperative, Laclede Electric \\
Cooperative, Lewis County \\
Rural Electric Cooperative, \\
Macon Electric Cooperative, \\
White River Valley Electric \\
Cooperative \\
\end{tabular} & varies by utility & $\begin{array}{l}\text { biomass, } \\
\text { wind }\end{array}$ & 2003 & $\begin{array}{l}2.0 \$ / \mathrm{kWh}- \\
3.5 \$ / \mathrm{kWh}\end{array}$ \\
\hline MO & City Utilities of Springfield & WindCurrent & wind & 2000 & $5.0 \phi / \mathrm{kWh}$ \\
\hline MT & $\begin{array}{l}\text { Basin Electric Power } \\
\text { Cooperative: Lower } \\
\text { Yellowstone, Powder River } \\
\text { Energy }\end{array}$ & Prairie Winds & wind & 2000 & $0.5 \$ / k W h$ \\
\hline MT & Northwestern Energy & $\underline{E}+$ Green & wind, PV & 2003 & $2.0 \phi / \mathrm{kWh}$ \\
\hline MT & Park Electric Cooperative & $\begin{array}{l}\text { Green Power } \\
\text { Program }\end{array}$ & $\begin{array}{l}\text { various } \\
\text { renewables }\end{array}$ & 2002 & $1.02 \$ / \mathrm{kWh}$ \\
\hline
\end{tabular}




\begin{tabular}{|c|c|c|c|c|c|}
\hline State & Utility Name & $\begin{array}{l}\text { Program } \\
\text { Name }\end{array}$ & Type & $\begin{array}{l}\text { Start } \\
\text { Date }\end{array}$ & Premium \\
\hline MT & $\begin{array}{l}\text { Southern Montana Electric } \\
\text { Generation and Transmission } \\
\text { Cooperative (5 coops offer } \\
\text { program): Fergus Electric, } \\
\text { Yellowstone Valley, Bear } \\
\text { Tooth Electric, Mid } \\
\text { Yellowstone, and Tongue } \\
\text { River }\end{array}$ & $\begin{array}{l}\text { Environmentally } \\
\text { Preferred Power }\end{array}$ & wind, hydro & 2002 & $1.05 \$ / \mathrm{kWh}$ \\
\hline MT & $\begin{array}{l}\text { Tri-State Generation \& } \\
\text { Transmission: Big Horn Rural } \\
\text { Electric Company }\end{array}$ & $\begin{array}{l}\text { Renewable } \\
\text { Resource Power } \\
\text { Service }\end{array}$ & wind, hydro & 2001 & $1.25 \phi / \mathrm{kWh}$ \\
\hline MT & Vigilante Electric Cooperative & $\begin{array}{l}\frac{\text { Alternative }}{\text { Renewable Energy }} \\
\text { Program }\end{array}$ & wind & 2003 & $1.1 థ / \mathrm{kWh}$ \\
\hline NE & Lincoln Electric System & $\begin{array}{l}\text { LES Renewable } \\
\text { Energy Program }\end{array}$ & wind & 1998 & $4.3 \phi / \mathrm{kWh}$ \\
\hline NE & Omaha Public Power District & $\begin{array}{l}\text { Green Power } \\
\text { Program }\end{array}$ & $\begin{array}{l}\text { landfill gas, } \\
\text { wind }\end{array}$ & 2002 & $3.0 \phi / \mathrm{kWh}$ \\
\hline NE & $\begin{array}{l}\text { Tri-State Generation \& } \\
\text { Transmission: Chimney Rock } \\
\text { Public Power District, Highline } \\
\text { Electric Association, } \\
\text { Northwest Rural Public Power } \\
\text { District }\end{array}$ & $\begin{array}{l}\text { Renewable } \\
\text { Resource Power } \\
\text { Service }\end{array}$ & wind, hydro & 2001 & $1.25 \phi / \mathrm{kWh}$ \\
\hline NM & El Paso Electric & $\begin{array}{l}\text { Renewable Energy } \\
\text { Tariff }\end{array}$ & wind & 2003 & $3.19 ф / k W h$ \\
\hline NM & $\begin{array}{l}\text { Los Alamos Department of } \\
\text { Public Utilities }\end{array}$ & Green Power & wind & 2005 & $1.8 థ / \mathrm{kWh}$ \\
\hline NM & Public Service of New Mexico & PNM Sky Blue & wind & 2003 & $1.8 థ / \mathrm{kWh}$ \\
\hline NM & $\begin{array}{l}\text { Tri-State Generation \& } \\
\text { Transmission: Central New } \\
\text { Mexico Electric Cooperative, } \\
\text { Inc., Columbus Electric } \\
\text { Cooperative, Inc., Continental } \\
\text { Divide Electric Cooperative, } \\
\text { Inc., Jemez Mountains Electric } \\
\text { Cooperative, Inc., Kit Carson } \\
\text { Electric Cooperative, Inc., } \\
\text { Northern Rio Arriba Electric } \\
\text { Cooperative, Otero County } \\
\text { Electric Cooperative, Inc., } \\
\text { Sierra Electric Cooperative, } \\
\text { Inc., Southwestern Electric } \\
\text { Cooperative, Inc., Springer } \\
\text { Electric Cooperative, Inc. }\end{array}$ & $\begin{array}{l}\text { Renewable } \\
\text { Resource Power } \\
\text { Service }\end{array}$ & wind, hydro & 2001 & $1.25 \phi / \mathrm{kWh}$ \\
\hline NM & Xcel Energy & WindSource & wind & 1999 & $3.0 \$ / \mathrm{kWh}$ \\
\hline NC & $\begin{array}{l}\text { Dominion North Carolina } \\
\text { Power }\end{array}$ & NC GreenPower & $\begin{array}{l}\text { biomass, } \\
\text { hydro, } \\
\text { landfill gas, } \\
\text { PV, wind }\end{array}$ & 2003 & $2.5 \phi-4.0 \phi / \mathrm{kWh}$ \\
\hline NC & Duke Energy & NC GreenPower & $\begin{array}{l}\text { biomass, } \\
\text { hydro, } \\
\text { landfill gas, } \\
\text { PV, wind }\end{array}$ & 2003 & $2.5 \phi-4.0 \phi / \mathrm{kWh}$ \\
\hline
\end{tabular}




\begin{tabular}{|c|c|c|c|c|c|}
\hline State & Utility Name & $\begin{array}{c}\text { Program } \\
\text { Name }\end{array}$ & Type & $\begin{array}{l}\text { Start } \\
\text { Date }\end{array}$ & Premium \\
\hline NC & $\begin{array}{l}\text { ElectriCities: Town of Apex, } \\
\text { Town of Cornelius, } \\
\text { Fayetteville PWC, Town of } \\
\text { Granite Falls, Greenville } \\
\text { Utilities, City of High Point, } \\
\text { City of Kinston, City of } \\
\text { Laurinburg, City of Lexington, } \\
\text { City of Monroe, City of New } \\
\text { Bern, City of Newton, City of } \\
\text { Shelby, City of Statesville, } \\
\text { Town of Wake Forest, City of } \\
\text { Washington, Town of } \\
\text { Waynesville }\end{array}$ & NC GreenPower & $\begin{array}{l}\text { biomass, } \\
\text { hydro, } \\
\text { landfill gas, } \\
\text { PV, wind }\end{array}$ & 2003 & $2.5 \phi-4.0 \phi / \mathrm{kWh}$ \\
\hline NC & $\begin{array}{l}\text { NC Electric Cooperatives (21 } \\
\text { of } 27 \text { coops offer program): } \\
\text { Albemarle Electric } \\
\text { Membership Corp., Blue Ridge } \\
\text { Electric Membership Corp., } \\
\text { Brunswick Electric } \\
\text { Membership Corp., Carteret } \\
\text { Craven Electric Coop., Central } \\
\text { Electric Membership Corp., } \\
\text { Edgecombe-Martin County } \\
\text { Electric Membership Corp., } \\
\text { Energy United, Four County } \\
\text { Electric Membership Corp., } \\
\text { French Broad Electric } \\
\text { Membership Corp., Haywood } \\
\text { Electric Membership Corp., } \\
\text { Jones-Onslow Electric } \\
\text { Membership Corp., Lumbee } \\
\text { River Electric Membership } \\
\text { Corp., Pee Dee Electric } \\
\text { Membership Corp., Piedmont } \\
\text { Electric Membership Corp., } \\
\text { Randolph Electric Membership } \\
\text { Corp., Roanoke Electric } \\
\text { Membership Corp., Rutherford } \\
\text { Electric Membership Corp., } \\
\text { Tideland Electric Membership } \\
\text { Corp., Tri-County Electric } \\
\text { Membership Corp., Union } \\
\text { Power Cooperative, Wake } \\
\text { Electric Membership Corp. }\end{array}$ & NC GreenPower & $\begin{array}{l}\text { biomass, } \\
\text { hydro, } \\
\text { landfill gas, } \\
\text { PV, wind }\end{array}$ & 2003 & $2.5 \$-4.0 \phi / k W h$ \\
\hline NC & Progress Energy / CP\&L & NC GreenPower & $\begin{array}{l}\text { biomass, } \\
\text { hydro, } \\
\text { landfill gas, } \\
\text { PV, wind }\end{array}$ & 2003 & $2.5 \$-4.0 \phi / \mathrm{kWh}$ \\
\hline NC & $\begin{array}{l}\text { TVA: Mountain Electric } \\
\text { Cooperative }\end{array}$ & $\begin{array}{l}\text { Green Power } \\
\text { Switch }\end{array}$ & $\begin{array}{l}\text { landfill gas, } \\
\text { PV, wind }\end{array}$ & 2000 & $2.67 \phi / k W h$ \\
\hline
\end{tabular}




\begin{tabular}{|c|c|c|c|c|c|}
\hline State & Utility Name & $\begin{array}{c}\text { Program } \\
\text { Name }\end{array}$ & Type & $\begin{array}{l}\text { Start } \\
\text { Date }\end{array}$ & Premium \\
\hline ND & $\begin{array}{l}\text { Basin Electric Power } \\
\text { Cooperative: Oliver Mercer } \\
\text { Electric Coop, Mor-gran-sou } \\
\text { Electric Coop, KEM Electric } \\
\text { Coop, North Central Electric } \\
\text { Coop, Verendrye, Capital } \\
\text { Northern Plains, Dakota } \\
\text { Valley, Burke Divide, Montrail } \\
\text { Williams, McKenzie Electric } \\
\text { Coop, West Plains, Slope } \\
\text { Electric Coop }\end{array}$ & PrairieWinds & wind & 2000 & $0.5 \phi / k W h$ \\
\hline ND & $\begin{array}{l}\text { Minnkota Power Cooperative: } \\
\text { Cass County Electric, Cavalier } \\
\text { Rural Electric, Nodak Electric } \\
\text { Northern Municipal Power } \\
\text { Agency ( } 2 \text { municipals) }\end{array}$ & $\begin{array}{l}\text { Infinity Wind } \\
\text { Energy }\end{array}$ & wind & 1999 & $0.5 \$ / \mathrm{kWh}$ \\
\hline ND & $\begin{array}{l}\text { Missouri River Energy } \\
\text { Services: City of Lakota }\end{array}$ & RiverWinds & wind & 2002 & $\begin{array}{l}2.0 \$ / \mathrm{kWh}- \\
2.5 \$ / \mathrm{kWh}\end{array}$ \\
\hline NV & Nevada Power & $\begin{array}{l}\text { Desert Research } \\
\text { Institute's } \\
\text { GreenPower } \\
\text { Program } \\
\end{array}$ & Solar PV & unknown & Contribution \\
\hline NV & $\begin{array}{l}\text { Deseret Power: Mt. Wheeler } \\
\text { Power Cooperative }\end{array}$ & Green Way & various & 2005 & $1.95 \phi / \mathrm{kWh}$ \\
\hline NV & Sierra Pacific Power & $\begin{array}{l}\text { Desert Research } \\
\text { Institute's } \\
\text { GreenPower } \\
\text { Program }\end{array}$ & Solar PV & unknown & Contribution \\
\hline $\mathrm{OH}$ & $\begin{array}{l}\text { American Municipal Power- } \\
\text { Ohio / Green Mountain } \\
\text { Energy: City of Bowling } \\
\text { Green, Cuyahoga Falls, } \\
\text { Wyandotte }\end{array}$ & Nature's Energy & $\begin{array}{l}\text { small hydro, } \\
\text { landfill gas, } \\
\text { wind }\end{array}$ & 2003 & $\begin{array}{l}1.3 \phi / \mathrm{kWh}- \\
1.5 \$ / \mathrm{kWh}\end{array}$ \\
\hline $\mathrm{OH}$ & Buckeye Power & EnviroWatts & landfill gas & 2006 & $2.0 \$ / \mathrm{kWh}$ \\
\hline $\mathrm{OH}$ & Duke Energy & GoGreen Power & $\begin{array}{l}\text { wind, PV, } \\
\text { landfill gas, } \\
\text { digester gas }\end{array}$ & 2001 & $2.5 \phi / \mathrm{kWh}$ \\
\hline OK & $\begin{array}{l}\text { Associated Electric } \\
\text { Cooperative, Inc.: Central } \\
\text { Rural Electric Cooperative }\end{array}$ & varies by utility & $\begin{array}{l}\text { biomass, } \\
\text { wind }\end{array}$ & 2003 & $\begin{array}{l}2.0 \$ / \mathrm{kWh}- \\
3.5 \$ / \mathrm{kWh}\end{array}$ \\
\hline OK & OG\&E Electric Services & OG\&E Wind Power & wind & 2003 & $-0.246 \$ / k W h$ \\
\hline OK & $\begin{array}{l}\text { Oklahoma Municipal Power } \\
\text { Authority: Tonkawa, Altus, } \\
\text { Frederick, Okeene, Praque } \\
\text { Municipal Utilities and } \\
\text { Edmond Electric }\end{array}$ & Pure \& Simple & wind & 2004 & $\begin{array}{l}1.8 \$ / \mathrm{kWh} \\
(-0.45 \phi / \mathrm{kWh} \\
\text { Edmond) }\end{array}$ \\
\hline
\end{tabular}




\begin{tabular}{|c|c|c|c|c|c|}
\hline State & Utility Name & $\begin{array}{c}\text { Program } \\
\text { Name }\end{array}$ & Type & $\begin{array}{l}\text { Start } \\
\text { Date }\end{array}$ & Premium \\
\hline OK & $\begin{array}{l}\text { Western Farmers Electric } \\
\text { Cooperative (19 of } 19 \text { coops } \\
\text { offer program): Alfalfa Electric } \\
\text { Cooperative, Caddo Electric } \\
\text { Cooperative, Canadian Valley } \\
\text { Electric Cooperative, Choctaw } \\
\text { Electri Cooperative, Cimmaron } \\
\text { Electric Cooperative, Cotton } \\
\text { Electric Cooperative, East } \\
\text { Central Oklahoma Electric } \\
\text { Cooperative, Harmon Electric } \\
\text { Cooperative, Kay Electric } \\
\text { Cooperative, Kiamichi Electric } \\
\text { Cooperative, Kiwash Electric } \\
\text { Cooperative, Northfork } \\
\text { Electric Cooperative, } \\
\text { Northwestern Electric } \\
\text { Cooperative, Oklahoma } \\
\text { Electric Cooperative, People's } \\
\text { Electric Cooperative, Red } \\
\text { River Valley Rural Electric } \\
\text { Cooperative, Rural Electric } \\
\text { Cooperative, Southeastern } \\
\text { Electric Cooperative, } \\
\text { Southwest Rural Electric } \\
\text { Cooperative } \\
\end{array}$ & WindWorks & wind & 2004 & $0.5 \$ / \mathrm{kWh}$ \\
\hline OR & $\begin{array}{l}\text { City of Ashland/Bonneville } \\
\text { Environmental Foundation }\end{array}$ & $\begin{array}{l}\text { Renewable } \\
\text { Pioneers }\end{array}$ & PV, wind & 2003 & $2.0 \phi / \mathrm{kWh}$ \\
\hline OR & Columbia River PUD & Choice Energy & wind & 2005 & $1.5 \$ / \mathrm{kWh}$ \\
\hline OR & $\begin{array}{l}\text { Emerald People's Utility } \\
\text { District/Green Mountain } \\
\text { Energy }\end{array}$ & $\begin{array}{l}\text { Choose } \\
\text { Renewable } \\
\text { Electricity }\end{array}$ & $\begin{array}{l}\text { wind, } \\
\text { geothermal }\end{array}$ & 2003 & $1.2 \phi / \mathrm{kWh}$ \\
\hline OR & $\begin{array}{l}\text { Eugene Water \& Electric } \\
\text { Board }\end{array}$ & EWEB Wind Power & wind & 1999 & $0.91 ф / k W h$ \\
\hline OR & $\begin{array}{l}\text { Eugene Water \& Electric } \\
\text { Board }\end{array}$ & $\begin{array}{l}\text { EWEB } \\
\text { Greenpower }\end{array}$ & $\begin{array}{l}\text { various } \\
\text { renewables }\end{array}$ & 2007 & $\begin{array}{l}1.0 \$ / \mathrm{kWh}- \\
1.5 \phi / \mathrm{kWh}\end{array}$ \\
\hline OR & Idaho Power & $\begin{array}{l}\text { Green Power } \\
\text { Program }\end{array}$ & various & 2001 & $0.98 \$ / k W h$ \\
\hline OR & Midstate Electric Cooperative & $\begin{array}{l}\text { Environmentally- } \\
\text { Preferred Power } \\
\end{array}$ & wind & 1999 & $2.5 \$ / \mathrm{kWh}$ \\
\hline OR & $\begin{array}{l}\text { Oregon Trail Electric } \\
\text { Cooperative }\end{array}$ & Green Power & wind & 2002 & $1.5 \$ / \mathrm{kWh}$ \\
\hline
\end{tabular}




\begin{tabular}{|c|c|c|c|c|c|}
\hline State & Utility Name & $\begin{array}{l}\text { Program } \\
\text { Name }\end{array}$ & Type & $\begin{array}{l}\text { Start } \\
\text { Date }\end{array}$ & Premium \\
\hline OR & 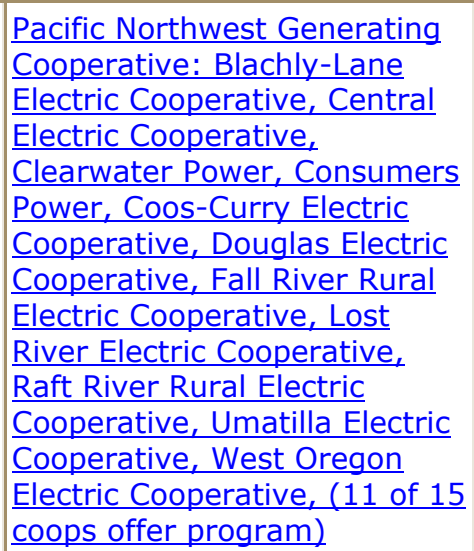 & Green Power & landfill gas & 1998 & $\begin{array}{l}1.8 \$ / \mathrm{kWh}- \\
2.0 \$ / \mathrm{kWh}\end{array}$ \\
\hline OR & PacifiCorp: Pacific Power & Blue Sky Block & wind & 2000 & $1.95 \phi / \mathrm{kWh}$ \\
\hline OR & PacifiCorp: Pacific Power & $\begin{array}{l}\text { Blue Sky QS } \\
\text { (Commercial } \\
\text { Only) }\end{array}$ & wind & 2004 & $\begin{array}{l}\text { Sliding scale } \\
\text { depending on } \\
\text { size }\end{array}$ \\
\hline OR & $\begin{array}{l}\text { PacifiCorp: Pacific Power / } 3 \\
\text { Degrees }\end{array}$ & Blue Sky Usage & $\begin{array}{l}\text { wind, } \\
\text { biomass, PV }\end{array}$ & 2002 & $0.78 \$ / k W h$ \\
\hline OR & $\begin{array}{l}\text { PacifiCorp: Pacific Power / } 3 \\
\text { Degrees }\end{array}$ & Blue Sky Habitat & $\begin{array}{l}\text { wind, } \\
\text { biomass, PV }\end{array}$ & 2002 & $\begin{array}{l}0.78 \phi / \mathrm{kWh}+ \\
\$ 2.50 / \mathrm{mo} . \\
\text { donation }\end{array}$ \\
\hline OR & $\begin{array}{l}\text { Portland General Electric } \\
\text { Company }\end{array}$ & Clean Wind Power & wind & 2002 & $1.75 \$ / \mathrm{kWh}$ \\
\hline OR & $\begin{array}{l}\text { Portland General Electric } \\
\text { Company }\end{array}$ & $\begin{array}{l}\text { Clean Wind for } \\
\text { Medium to Large } \\
\text { Commercial \& } \\
\text { Industrial } \\
\text { Accounts } \\
\end{array}$ & wind & 2003 & $1.7 \$ / \mathrm{kWh}$ \\
\hline OR & $\begin{array}{l}\text { Portland General Electric } \\
\text { Company / Green Mountain } \\
\text { Energy }\end{array}$ & Renewable Future & wind & 2007 & $1.5 \phi / \mathrm{kWh}$ \\
\hline OR & $\begin{array}{l}\text { Portland General Electric } \\
\text { Company / Green Mountain } \\
\text { Energy }\end{array}$ & Green Source & $\begin{array}{l}\text { existing } \\
\text { geothermal, } \\
\text { hydro, new } \\
\text { wind }\end{array}$ & 2002 & $0.8 థ / \mathrm{kWh}$ \\
\hline SC & $\begin{array}{l}\text { Santee Cooper: Aiken Electric } \\
\text { Cooperative, Berkeley Electric } \\
\text { Cooperative, Blue Ridge } \\
\text { Electric, Coastal Electric } \\
\text { Cooperative, Edisto Electric } \\
\text { Cooperative, Fairfield Electric } \\
\text { Cooperative, Horry Electric } \\
\text { Cooperative, Laurens Electric } \\
\text { Cooperative, Lynches River } \\
\text { Electric Cooperative, Marlboro } \\
\text { Electric Cooperative, Mid- } \\
\text { Carolina Electric Cooperative, } \\
\text { Palmetto Electric Cooperative } \\
\text { Pee Dee Electric Cooperative } \\
\text { Santee Electric Cooperative, } \\
\text { Tri-County Electric } \\
\text { Cooperative, York Electric } \\
\text { Cooperative }\end{array}$ & $\frac{\text { Green Power }}{\text { Program }}$ & landfill gas & 2001 & $3.0 \$ / \mathrm{kWh}$ \\
\hline
\end{tabular}




\begin{tabular}{|c|c|c|c|c|c|}
\hline State & Utility Name & $\begin{array}{c}\text { Program } \\
\text { Name }\end{array}$ & Type & $\begin{array}{l}\text { Start } \\
\text { Date }\end{array}$ & Premium \\
\hline SD & $\begin{array}{l}\text { Basin Electric Power } \\
\text { Cooperative: Bon Homme- } \\
\text { Yankton Electric Assn., } \\
\text { Central Electric Cooperative } \\
\text { Association, Charles Mix } \\
\text { Electric Association, City of } \\
\text { Elk Point, Clay-Union Electric } \\
\text { Corporation, Codington-Clark } \\
\text { Electric Cooperative, Dakota } \\
\text { Energy Cooperative, Douglas } \\
\text { Electric Cooperative, FEM } \\
\text { Electric Association, H-D } \\
\text { Electric Cooperative, } \\
\text { Kingsbury Electric } \\
\text { Cooperative, Lyon-Lincoln } \\
\text { Electric Cooperative, McCook } \\
\text { Electric Cooperative, Northern } \\
\text { Electric Cooperative, Oahe } \\
\text { Electric Cooperative, Renville- } \\
\text { Sibley Coop. Power Assn., } \\
\text { Sioux Valley Southwestern } \\
\text { Electric Coop, Southeastern } \\
\text { Electric Coop, Union County } \\
\text { Electric Cooperative, } \\
\text { Whetstone Valley Electric } \\
\text { Cooperative, Black Hills } \\
\text { Electric Coop, LaCreek Electric } \\
\text { Coop, West River Power } \\
\text { Association, Butte Electric } \\
\text { Coop, Cherry Todd Electric } \\
\text { Coop, Moreau Grand, Grand } \\
\text { Electric Cooperative, Rosebud } \\
\end{array}$ & Prairie Winds & wind & 2000 & $0.5 \$ / \mathrm{kWh}$ \\
\hline SD & $\begin{array}{l}\text { Missouri River Energy } \\
\text { Services: City of Vermillion }\end{array}$ & RiverWinds & wind & 2002 & $\begin{array}{l}2.0 \$ / \mathrm{kWh}- \\
2.5 \$ / \mathrm{kWh}\end{array}$ \\
\hline SD & $\begin{array}{l}\text { Tri-State Generation \& } \\
\text { Transmission: Niobrara } \\
\text { Electric Association, Inc. }\end{array}$ & $\begin{array}{l}\text { Renewable } \\
\text { Resource Power } \\
\text { Service }\end{array}$ & wind, hydro & 2001 & $1.25 \phi / \mathrm{kWh}$ \\
\hline
\end{tabular}




\begin{tabular}{|c|c|c|c|c|c|}
\hline State & Utility Name & $\begin{array}{c}\text { Program } \\
\text { Name }\end{array}$ & Type & $\begin{array}{l}\text { Start } \\
\text { Date }\end{array}$ & Premium \\
\hline TN & $\begin{array}{l}\text { TVA: Alcoa Electric } \\
\text { Department, Appalachian } \\
\text { Electric Cooperative, Athens } \\
\text { Utility Board, Bristol } \\
\text { Tennessee Electric System, } \\
\text { Caney Fork Electric } \\
\text { Cooperative, City of Maryville } \\
\text { Electric Department, } \\
\text { Clarksville Department of } \\
\text { Electricity, Cleveland Utilities, } \\
\text { Clinton Utilities Board, } \\
\text { Cookeville Electric } \\
\text { Department, Cumberland } \\
\text { Electric Membership } \\
\text { Corporation, Dickson Electric } \\
\text { Department, Duck River } \\
\text { Electric Membership } \\
\text { Corporation, Elizabethton } \\
\text { Electric System, EPB } \\
\text { Chattanooga), Erwin Utilities, } \\
\text { Fayetteville Public Utilities, } \\
\text { Gibson Electric Membership } \\
\text { Corporation, Greeneville Light } \\
\text { and Power System, Harriman } \\
\text { Utility Board, Johnson City } \\
\text { Power Board, Jackson Energy } \\
\text { Authority, Knoxville Utilities } \\
\text { Board, Lafollette Utilities } \\
\text { Board, Lawrenceburg Power } \\
\text { System, Lenoir City Utilities } \\
\text { Board, Loudon Utilities, } \\
\text { McMinnville Electric System, } \\
\text { Memphis Light, Gas \& Water } \\
\text { Meriwhether Lewis Electric } \\
\text { Cooperative, Middle } \\
\text { Tennessee Electric } \\
\text { Membership Corporation, } \\
\text { Morristown Power System, } \\
\text { Mountain Electric Cooperative, } \\
\text { Murfreesboro Electric } \\
\text { Department, Nashville Electric } \\
\text { Service, Newport Utilities, Oak } \\
\text { Ridge Electric Department, } \\
\text { Paris Board of Public Utilities, } \\
\text { Plateau Electric Cooperative, } \\
\text { Powell Valley Electric } \\
\text { Cooperative, Pulaski Electric } \\
\text { System, Sequachee Valley } \\
\text { Electric Cooperative, Sevier } \\
\text { County Electric System, } \\
\text { Springfield Department of } \\
\text { Electricity, Sweetwater } \\
\text { Utilities Board, Tullahoma } \\
\text { Utilities Board, Upper } \\
\text { Cumberland Electric } \\
\text { Membership Corporation, } \\
\text { Volunteer Energy Cooperative }\end{array}$ & $\begin{array}{l}\text { Green Power } \\
\text { Switch }\end{array}$ & $\begin{array}{l}\text { landfill gas, } \\
\text { PV, wind }\end{array}$ & 2000 & $2.67 \$ / \mathrm{kWh}$ \\
\hline$T X$ & Austin Energy (City of Austin) & GreenChoice & $\begin{array}{l}\text { wind, landfill } \\
\text { gas }\end{array}$ & 2000/1997 & $-0.134 \phi / k W h$ \\
\hline
\end{tabular}




\begin{tabular}{|c|c|c|c|c|c|}
\hline State & Utility Name & $\begin{array}{c}\text { Program } \\
\text { Name }\end{array}$ & Type & $\begin{array}{l}\text { Start } \\
\text { Date }\end{array}$ & Premium \\
\hline TX & Bandera Electric Cooperative & Choose-To-Renew & wind, hydro & 2005 & $-0.114 \phi / \mathrm{kWh}$ \\
\hline TX & CPS Energy (San Antonio) & Windtricity & wind & 2000 & $3.0 \$ / \mathrm{kWh}$ \\
\hline TX & El Paso Electric Company & $\begin{array}{l}\text { Renewable Energy } \\
\text { Tariff }\end{array}$ & wind & 2001 & $1.92 థ / \mathrm{kWh}$ \\
\hline TX & $\begin{array}{l}\text { Pedernales Electric } \\
\text { Cooperative }\end{array}$ & Renewable Power & wind, hydro & 2006 & $0.5 \phi / \mathrm{kWh}$ \\
\hline UT & City of St. George & $\begin{array}{l}\text { Clean Green } \\
\text { Power }\end{array}$ & $\begin{array}{l}\text { wind, small } \\
\text { hydro }\end{array}$ & 2005 & $2.95 \$ / k W h$ \\
\hline UT & Deseret Power & GreenWay & various & 2004 & $1.95 \$ / \mathrm{kWh}$ \\
\hline UT & $\begin{array}{l}\text { PacifiCorp: Rocky Mountain } \\
\text { Power }\end{array}$ & Blue Sky & wind & 2003 & $\begin{array}{l}0.71 \phi / \mathrm{kWh}- \\
1.94 \phi / \mathrm{kWh}\end{array}$ \\
\hline UT & PacifiCorp: Utah Power & Blue Sky & wind & 2000 & $1.95 \$ / k W h$ \\
\hline UT & $\begin{array}{l}\text { Tri-State Generation \& } \\
\text { Transmission: Empire Electric } \\
\text { Association, Inc. }\end{array}$ & $\begin{array}{l}\text { Renewable } \\
\text { Resource Power } \\
\text { Service }\end{array}$ & wind, hydro & 2001 & $1.25 \phi / \mathrm{kWh}$ \\
\hline VT & $\begin{array}{l}\text { Central Vermont Public } \\
\text { Service }\end{array}$ & CVPS Cow Power & biogas & 2004 & $4.0 \$ / \mathrm{kWh}$ \\
\hline VT & Green Mountain Power & $\begin{array}{l}\text { Greener Mountain } \\
\text { Power }\end{array}$ & $\begin{array}{l}\text { various } \\
\text { renewables }\end{array}$ & 2006 & $\begin{array}{l}4.097 \$ / \mathrm{kWh}- \\
4.38 \$ / \mathrm{kWh}\end{array}$ \\
\hline VT & Green Mountain Power & \begin{tabular}{|l} 
CoolHome / \\
CoolBusiness \\
\end{tabular} & $\begin{array}{l}\text { wind, } \\
\text { biomass }\end{array}$ & 2002 & Contribution \\
\hline WA & Avista Utilities & Buck-A-Block & wind & 2002 & $0.33 \phi / \mathrm{kWh}$ \\
\hline WA & $\begin{array}{l}\text { Benton County Public Utility } \\
\text { District }\end{array}$ & \begin{tabular}{|l} 
Green Power \\
Program
\end{tabular} & $\begin{array}{l}\text { landfill gas, } \\
\text { wind, hydro }\end{array}$ & 1999 & Contribution \\
\hline WA & Chelan County PUD & $\begin{array}{l}\text { Sustainable } \\
\text { Natural } \\
\text { Alternative Power } \\
\text { (SNAP) } \\
\end{array}$ & $\begin{array}{l}\mathrm{PV}, \text { wind, } \\
\text { micro hydro }\end{array}$ & 2001 & Contribution \\
\hline WA & Clallam County PUD & $\begin{array}{l}\text { Clallam County } \\
\text { PUD Green Power } \\
\text { Program }\end{array}$ & landfill gas & 2001 & $0.69 \phi / k W h$ \\
\hline WA & Clark Public Utilities & Green Lights & PV, wind & 2002 & $1.5 \$ / \mathrm{kWh}$ \\
\hline WA & Cowlitz PUD & $\begin{array}{l}\text { Renewable } \\
\text { Resource Energy } \\
\end{array}$ & wind, PV & 2002 & $2.0 \$ / \mathrm{kWh}$ \\
\hline WA & Grant County PUD & \begin{tabular}{|l} 
Alternative \\
Energy Resources \\
Program
\end{tabular} & wind & 2002 & $2.0 \$ / \mathrm{kWh}$ \\
\hline WA & Grays Harbor PUD & Green Power & wind & 2002 & $3.0 \$ / \mathrm{kWh}$ \\
\hline WA & Lewis County PUD & $\begin{array}{l}\text { Green Power } \\
\text { Energy Rate }\end{array}$ & wind & 2003 & $2.0 \$ / \mathrm{kWh}$ \\
\hline WA & Mason County PUD No. 3 & $\begin{array}{l}\text { Mason Evergreen } \\
\text { Power }\end{array}$ & wind & 2003 & $1.0 \phi / \mathrm{kWh}$ \\
\hline WA & Northen Wasco County PUD & Pure Power & wind & 2007 & $2.5 \$ / \mathrm{kWh}$ \\
\hline WA & Orcas Power \& Light & Go Green & wind, hydro & 1999 & $3.5 \$ / k W h$ \\
\hline WA & Pacific County PUD & Green Power & landfill gas & 2002 & $1.05 \phi / \mathrm{kWh}$ \\
\hline WA & Pacificorp: Pacific Power & Blue Sky & wind & 2000 & $1.95 \phi / \mathrm{kWh}$ \\
\hline WA & Peninsula Light & Green by Choice & $\begin{array}{l}\text { wind, hydro, } \\
\text { biogas }\end{array}$ & 2002 & $2.0 \$ / \mathrm{kWh}$ \\
\hline
\end{tabular}




\begin{tabular}{|c|c|c|c|c|c|}
\hline State & Utility Name & $\begin{array}{l}\text { Program } \\
\text { Name }\end{array}$ & Type & $\begin{array}{l}\text { Start } \\
\text { Date }\end{array}$ & Premium \\
\hline WA & Puget Sound Energy & $\begin{array}{l}\text { Green Power } \\
\text { Program }\end{array}$ & $\begin{array}{l}\text { wind, PV, } \\
\text { biogas }\end{array}$ & 2002 & $1.25 \phi / \mathrm{kWh}$ \\
\hline WA & Seattle City Light & $\begin{array}{l}\text { Seattle Green } \\
\text { Power }\end{array}$ & PV, biogas & 2002 & Contribution \\
\hline WA & Seattle City Light & Green Up & wind & 2005 & $1.5 \$ / \mathrm{kWh}$ \\
\hline WA & $\begin{array}{l}\text { Snohomish County Public } \\
\text { Utility District }\end{array}$ & Planet Power & wind & 2002 & $2.0 \phi / \mathrm{kWh}$ \\
\hline WA & Tacoma Power & EverGreen & wind & 2000 & $1.2 \phi / \mathrm{kWh}$ \\
\hline WI & Alliant Energy & Second Nature & $\begin{array}{l}\text { wind, landfill } \\
\text { gas }\end{array}$ & 2000 & $2.0 \phi / \mathrm{kWh}$ \\
\hline WI & $\begin{array}{l}\text { Dairyland Power Cooperative: } \\
\text { Barron Electric, Bayfield/ Iron } \\
\text { River, Chippewa / Cornell } \\
\text { Valley, Clark / Greenwood, } \\
\text { Dunn / Menomonie, Eau Claire } \\
\text { /Fall Creek, Jackson / Black } \\
\text { River Falls, Jump River / } \\
\text { Ladysmith, Oakdale, Pierce- } \\
\text { Pepin / Ellsworth, Polk- } \\
\text { Burnett / Centuria, Price / } \\
\text { Phillips, Richland, Riverland / } \\
\text { Arcadia, St. Croix / Baldwin, } \\
\text { Scenic Rivers / Lancaster, } \\
\text { Taylor / Medford, Vernon / } \\
\text { Westby }\end{array}$ & $\frac{\text { Evergreen }}{\text { Renewable Energy }}$ & $\begin{array}{l}\text { hydro, wind, } \\
\text { landfill gas, } \\
\text { biogas }\end{array}$ & 1998 & $1.5 \phi / \mathrm{kWh}$ \\
\hline WI & $\begin{array}{l}\text { Great River Energy: Head of } \\
\text { the Lakes }\end{array}$ & $\begin{array}{l}\frac{\text { Wellspring }}{\text { Renewable Wind }} \\
\text { Energy Program }\end{array}$ & wind & 1997 & $\begin{array}{l}1.45 \phi / \mathrm{kWh}- \\
2.0 \phi / \mathrm{kWh}\end{array}$ \\
\hline WI & Madison Gas \& Electric & $\begin{array}{l}\text { Wind Power } \\
\text { Program }\end{array}$ & wind & 1999 & $2.68 థ / \mathrm{kWh}$ \\
\hline WI & We Energies & $\begin{array}{l}\text { Energy for } \\
\text { Tomorrow }\end{array}$ & $\begin{array}{l}\text { landfill gas, } \\
\text { PV, hydro, } \\
\text { wind }\end{array}$ & 1996 & $1.37 \phi / \mathrm{kWh}$ \\
\hline WI & $\begin{array}{l}\text { Wisconsin Public Power Inc. } \\
\text { (34 of } 37 \text { munis offer } \\
\text { program): Algoma, } \\
\text { Cedarburg, Florence, } \\
\text { Kaukauna, Muscoda, } \\
\frac{\text { Stoughton, Reedsburg, }}{\text { Oconomowoc, Waterloo, }} \\
\frac{\text { Whitehall, Columbus, }}{\text { Hartford, Lake Mills, New }} \\
\text { Holstein, Richland Center, } \\
\text { Boscobel, Cuba City, } \\
\text { Hustisford, Sturgeon Bay, } \\
\text { Waunakee, Lodi, New London, } \\
\text { Plymouth, River Falls, Sun } \\
\text { Prairie, Waupun, Eagle River, } \\
\text { Jefferson, Menasha, New } \\
\text { Richmond, Prairie du Sac, } \\
\text { Slinger, Two Rivers, Westby } \\
\end{array}$ & $\begin{array}{l}\text { Renewable Energy } \\
\text { Program }\end{array}$ & $\begin{array}{l}\text { small hydro, } \\
\text { wind, biogas }\end{array}$ & 2001 & $2.0 \$ / \mathrm{kWh}$ \\
\hline WI & Wisconsin Public Service & NatureWise & $\begin{array}{l}\text { wind, landfill } \\
\text { gas, biogas }\end{array}$ & 2002 & $1.86 \phi / \mathrm{kWh}$ \\
\hline
\end{tabular}




\begin{tabular}{|c|c|c|c|c|c|}
\hline State & Utility Name & $\begin{array}{l}\text { Program } \\
\text { Name }\end{array}$ & Type & $\begin{array}{l}\text { Start } \\
\text { Date }\end{array}$ & Premium \\
\hline WI & Wisconsin Public Service & $\begin{array}{l}\text { Solar Wise for } \\
\text { Schools }\end{array}$ & PV in schools & 1996 & Contribution \\
\hline WY & $\begin{array}{l}\text { Basin Electric Power } \\
\text { Cooperative: Powder River } \\
\text { Energy }\end{array}$ & Prairie Winds & wind & 2000 & $0.5 \$ / \mathrm{kWh}$ \\
\hline WY & $\begin{array}{l}\text { Cheyenne Light, Fuel and } \\
\text { Power Company/Bonneville } \\
\text { Environmental Foundation }\end{array}$ & $\begin{array}{l}\text { Renewable } \\
\text { Premium Program } \\
\end{array}$ & $\begin{array}{l}99 \% \text { new } \\
\text { wind, } 1 \% \\
\text { new solar }\end{array}$ & 2006 & $3.5 \phi / \mathrm{kWh}$ \\
\hline WY & Lower Valley Energy & Green Power & wind & 2003 & $1.167 \$ / \mathrm{kWh}$ \\
\hline WY & Pacificorp: Pacific Power & Blue Sky & wind & 2000 & $1.95 \$ / \mathrm{kWh}$ \\
\hline WY & $\begin{array}{l}\text { Tri-State Generation \& } \\
\text { Transmission: Carbon Power } \\
\text { \& Light, Inc. }\end{array}$ & $\begin{array}{l}\text { Renewable } \\
\text { Resource Power } \\
\text { Service }\end{array}$ & wind, hydro & 2001 & $1.25 \phi / \mathrm{kWh}$ \\
\hline WY & $\begin{array}{l}\text { Yampa Valley Electric } \\
\text { Association } \\
\end{array}$ & $\begin{array}{l}\text { Wind Energy } \\
\text { Program }\end{array}$ & wind & 1999 & $3.0 \notin / \mathrm{kWh}$ \\
\hline
\end{tabular}

Notes: Utility green pricing programs may only be available to customers located in the utility's service territory. Source: National Renewable Energy Laboratory, Golden, Colorado. 


\section{Appendix F}

Table F-1. State-Specific Retail Green Power Product Offerings ${ }^{1}$ in Competitive
Electricity Markets, October 2007

\begin{tabular}{|c|c|c|c|c|}
\hline State & Company & Product Name & $\begin{array}{l}\text { Resource } \\
\text { Mix }^{2}\end{array}$ & Certification \\
\hline CT & 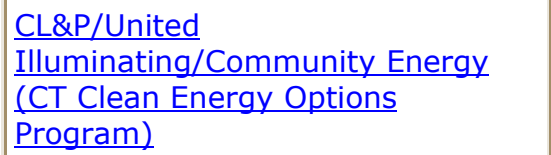 & $\begin{array}{l}\text { NewWind } \\
\text { Energy/Landfill Gas } \\
\underline{50 \% \text { or } 100 \% \text { of usage }}\end{array}$ & $\begin{array}{l}50 \% \text { new wind, } 50 \% \\
\text { landfill gas }\end{array}$ & - \\
\hline CT & $\begin{array}{l}\text { CL\&P/United Illuminating/Sterling } \\
\text { Planet (CT Clean Energy Options } \\
\text { Program) }\end{array}$ & $\begin{array}{l}\text { Sterling Select } 50 \% \text { or } \\
100 \% \text { of usage }\end{array}$ & $\begin{array}{l}33 \% \text { new wind, } 33 \% \\
\text { small hydro, } 34 \% \\
\text { landfill gas }\end{array}$ & - \\
\hline CT & $\begin{array}{l}\text { Levco (CL\&P and UI customers } \\
\text { only) }\end{array}$ & $\begin{array}{l}100 \% \text { Renewable } \\
\text { Electricity Program }\end{array}$ & $\begin{array}{l}100 \% \text { CT Class II } \\
\text { qualifying } \\
\text { renewables }\end{array}$ & - \\
\hline DC & PEPCO Energy Services ( 3 ) & $\begin{array}{l}\text { Green Electricity } 100 \% \\
\text { of usage }\end{array}$ & landfill gas & - \\
\hline DC & PEPCO Energy Services (3) & $\begin{array}{l}\text { NewWind Energy } 100 \% \\
\text { of usage }\end{array}$ & new wind & - \\
\hline DC & $\begin{array}{l}\text { Washington Gas Energy Services / } \\
\text { Community Energy (3) }\end{array}$ & $\begin{array}{l}\text { 1-Year Fixed Price } \\
\text { Electricity with } 5 \% \\
\text { Wind }\end{array}$ & $5 \%$ new wind & - \\
\hline MA & Cape Light Compact & $\begin{array}{l}\text { Cape Light Compact } \\
\text { Green } 50 \% \text { or } 100 \% *\end{array}$ & $\begin{array}{l}75 \% \text { small hydro, } \\
24 \% \text { new wind or } \\
\text { landfill gas, } 1 \% \text { new } \\
\text { solar }\end{array}$ & - \\
\hline MA & $\begin{array}{l}\text { Massachusetts Electric / Nantucket } \\
\text { Electric / Clear Sky Power (5) }\end{array}$ & Clear Sky Home* & $100 \%$ biomass & - \\
\hline MA & $\begin{array}{l}\text { Massachusetts Electric/Nantucket } \\
\text { Electric/Community Energy (5) }\end{array}$ & $\begin{array}{l}\text { New Wind Energy and } \\
\text { Water } 50 \% \text { or } 100 \% \text { of } \\
\text { usage* }\end{array}$ & $\begin{array}{l}70 \% \text { small hydro, } \\
30 \% \text { new wind }\end{array}$ & Green-e \\
\hline MA & $\begin{array}{l}\text { Massachusetts Electric/Nantucket } \\
\text { Electric/Mass Energy Consumers } \\
\text { Alliance }\end{array}$ & 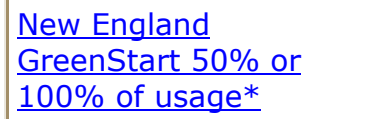 & $\begin{array}{l}75 \% \text { small hydro, } \\
25 \% \text { new biomass, } \\
\text { wind, and solar }\end{array}$ & - \\
\hline MA & $\begin{array}{l}\text { Massachusetts Electric/Nantucket } \\
\text { Electric/Sterling Planet (5) }\end{array}$ & MA Clean Choice* & $\begin{array}{l}33 \% \text { new wind, } 33 \% \\
\text { new landfill gas, } \\
33 \% \text { small hydro }\end{array}$ & $\begin{array}{l}\text { Environmental } \\
\text { Resources Trust }\end{array}$ \\
\hline MD & PEPCO Energy Services & $\begin{array}{l}\text { Green Electricity } 100 \% \\
\text { of usage }\end{array}$ & landfill gas & - \\
\hline MD & PEPCO Energy Services & $\begin{array}{l}\text { NewWind Energy } 100 \% \\
\text { of usage }\end{array}$ & new wind & - \\
\hline MD & $\begin{array}{l}\text { Washington Gas Energy Services / } \\
\text { Community Energy (4) }\end{array}$ & $\begin{array}{l}\text { 1-Year Fixed Price } \\
\text { Electricity with } 5 \% \\
\text { Wind }\end{array}$ & $5 \%$ wind & - \\
\hline ME & $\begin{array}{l}\text { Kennebunk Light and Power } \\
\text { District }\end{array}$ & Village Green & hydro, landfill gas & - \\
\hline ME & $\begin{array}{l}\text { Maine Renewable Energy/Maine } \\
\text { Interfaith Power \& Light }\end{array}$ & Maine Clean Power & $\begin{array}{l}100 \% \text { low impact } \\
\text { hydro }\end{array}$ & - \\
\hline
\end{tabular}




\begin{tabular}{|c|c|c|c|c|}
\hline State & Company & Product Name & $\begin{array}{l}\text { Resource } \\
\text { Mix }^{2}\end{array}$ & Certification \\
\hline ME & $\begin{array}{l}\text { Maine Renewable Energy/Maine } \\
\text { Interfaith Power \& Light }\end{array}$ & Maine Clean Power Plus & $\begin{array}{l}80 \% \text { low impact } \\
\text { hydro, } 20 \% \text { wind }\end{array}$ & - \\
\hline NJ & $\begin{array}{l}\text { PSE\&G/JCP\&L/Atlantic City } \\
\text { Electric/Rockland } \\
\text { Electric/Community Energy }\end{array}$ & $\begin{array}{l}\text { NJ Clean Power Choice } \\
\text { - Community Energy }\end{array}$ & $\begin{array}{l}50 \% \text { wind, } 49 \% \text { low } \\
\text { impact hydro, } 1 \% \\
\text { solar }\end{array}$ & - \\
\hline NJ & $\begin{array}{l}\text { PSE\&G/JCP\&L/Atlantic City } \\
\text { Electric/Rockland Electric/Green } \\
\text { Mountain Energy }\end{array}$ & $\begin{array}{l}\text { NJ Clean Power Choice } \\
\text { - Green Mountain } \\
\text { Energy }\end{array}$ & $\begin{array}{l}50 \% \text { wind, } 50 \% \text { low } \\
\text { impact hydro }\end{array}$ & - \\
\hline NJ & $\begin{array}{l}\text { PSE\&G/JCP\&L/Atlantic City } \\
\text { Electric/Rockland Electric/Jersey- } \\
\text { Atlantic Wind }\end{array}$ & $\begin{array}{l}\text { NJ Clean Power Choice } \\
\text {-Wind }\end{array}$ & $\begin{array}{l}\text { 100-kWh blocks of } \\
\text { new wind }\end{array}$ & - \\
\hline NJ & $\begin{array}{l}\text { PSE\&G/JCP\&L/Atlantic City } \\
\text { Electric/Rockland Electric/Jersey- } \\
\text { Atlantic Wind }\end{array}$ & $\begin{array}{l}\text { NJ Clean Power Choice } \\
\text { - Wind and Water }\end{array}$ & $\begin{array}{l}50 \% \text { wind, } 50 \% \text { low } \\
\text { impact hydro }\end{array}$ & - \\
\hline NJ & $\begin{array}{l}\text { PSE\&G/JCP\&L/Atlantic City } \\
\text { Electric/Rockland Electric/Sterling } \\
\text { Planet }\end{array}$ & $\begin{array}{l}\text { NJ Clean Power Choice } \\
\text { - Sterling Select }\end{array}$ & $\begin{array}{l}33 \% \text { wind, } 33 \% \\
\text { small hydro, } 34 \% \\
\text { landfill gas }\end{array}$ & $\begin{array}{l}\text { Environmental } \\
\text { Resources trust }\end{array}$ \\
\hline NY & Accent Energy & $\begin{array}{l}\text { GoGreen (ConEd, } \\
\text { Central Hudson and } \\
\text { NIMO only) }\end{array}$ & $100 \%$ NY hydro & - \\
\hline NY & Accent Energy & $\begin{array}{l}\text { GoGreen Premium } \\
\text { (ConEd, Central } \\
\text { Hudson and NIMO } \\
\text { only) }\end{array}$ & $100 \%$ wind & Green-e \\
\hline NY & $\begin{array}{l}\text { ConEdison Solutions / Community } \\
\text { Energy }\end{array}$ & GREEN Power & $\begin{array}{l}35 \% \text { new wind, } 65 \% \\
\text { small hydro }\end{array}$ & Green-e \\
\hline NY & Econnergy & Keep It Green & $100 \%$ wind & - \\
\hline NY & $\begin{array}{l}\text { Energy Cooperative of New York } \\
(6)\end{array}$ & Renewable Electricity & $\begin{array}{l}25 \% \text { new wind, } 75 \% \\
\text { landfill gas }\end{array}$ & - \\
\hline NY & IDT Energy & Buy Green & $100 \%$ hydro & - \\
\hline NY & $\begin{array}{l}\text { Long Island Power Authority / } \\
\text { Community Energy }\end{array}$ & New Wind Energy & new wind & - \\
\hline NY & $\begin{array}{l}\text { Long Island Power Authority / } \\
\text { Community Energy }\end{array}$ & $\begin{array}{l}\text { New Wind } \\
\text { Energy/Small Hydro }\end{array}$ & $\begin{array}{l}60 \% \text { new wind, } 40 \% \\
\text { small hydro }\end{array}$ & - \\
\hline NY & $\begin{array}{l}\text { Long Island Power Authority / } \\
\text { EnviroGen }\end{array}$ & Green Power Program & $\begin{array}{l}75 \% \text { landfill gas, } \\
25 \% \text { small hydro }\end{array}$ & - \\
\hline NY & $\begin{array}{l}\text { Long Island Power Authority / } \\
\text { Sterling Planet }\end{array}$ & New York Clean & $\begin{array}{l}55 \% \text { small hydro, } \\
35 \% \text { bioenergy, } \\
10 \% \text { wind }\end{array}$ & $\begin{array}{l}\text { Environmental } \\
\text { Resources Trust }\end{array}$ \\
\hline NY & $\begin{array}{l}\text { Long Island Power Authority / } \\
\text { Sterling Planet }\end{array}$ & $\underline{\text { Sterling Green }}$ & $\begin{array}{l}40 \% \text { new wind, } 30 \% \\
\text { small hydro, } 30 \% \\
\text { bioenergy }\end{array}$ & $\begin{array}{l}\text { Environmental } \\
\text { Resources Trust }\end{array}$ \\
\hline NY & National Grid / Community Energy & $\begin{array}{l}60 \% \text { New Wind Energy } \\
\text { and } 40 \% \text { Small Hydro }\end{array}$ & $\begin{array}{l}60 \% \text { new wind, } 40 \% \\
\text { hydro }\end{array}$ & - \\
\hline NY & National Grid / Community Energy & NewWind Energy & $100 \%$ new wind & - \\
\hline NY & National Grid / EnviroGen & Think Green! & $\begin{array}{l}75 \% \text { landfill gas, } \\
25 \% \text { low impact } \\
\text { hydro }\end{array}$ & - \\
\hline
\end{tabular}




\begin{tabular}{|c|c|c|c|c|}
\hline State & Company & Product Name & $\begin{array}{l}\text { Resource } \\
\text { Mix }^{2}\end{array}$ & Certification \\
\hline NY & $\begin{array}{l}\text { National Grid / Green Mountain } \\
\text { Energy }\end{array}$ & $\begin{array}{l}\text { Green Mountain Energy } \\
\text { Electricity }\end{array}$ & $\begin{array}{l}50 \% \text { small hydro, } \\
50 \% \text { wind }\end{array}$ & Green-e \\
\hline NY & National Grid / Sterling Planet & $\underline{\text { Sterling Green }}$ & $\begin{array}{l}50 \% \text { wind, } 50 \% \\
\text { small hydro }\end{array}$ & $\begin{array}{l}\text { Environmental } \\
\text { Resources Trust }\end{array}$ \\
\hline NY & NYSEG/Community Energy & $\begin{array}{l}\text { Catch the Wind/New } \\
\text { Wind Energy }\end{array}$ & new wind & - \\
\hline NY & $\begin{array}{l}\text { Rochester Gas \& } \\
\text { Electric/Community Energy }\end{array}$ & $\begin{array}{l}\text { Catch the } \\
\text { Wind/NewWind Energy }\end{array}$ & $\begin{array}{l}\text { 100-kWh blocks of } \\
\text { new wind }\end{array}$ & - \\
\hline NY & $\underline{\text { Sterling Planet }}$ & NY Clean Choice & $\begin{array}{l}40 \% \text { new wind, } 30 \% \\
\text { small hydro, } 30 \% \\
\text { bioenergy }\end{array}$ & $\begin{array}{l}\text { Environmental } \\
\text { Resources Trust }\end{array}$ \\
\hline NY & $\begin{array}{l}\text { Suburban Energy Services } \\
\text { LSterling Planet }\end{array}$ & $\begin{array}{l}\text { Sterling Green } \\
\text { Renewable Electricity }\end{array}$ & $\begin{array}{l}40 \% \text { new wind, } 30 \% \\
\text { small hydro, } 30 \% \\
\text { bioenergy }\end{array}$ & $\begin{array}{l}\text { Environmental } \\
\text { Resources Trust }\end{array}$ \\
\hline PA & Commerce Energy & $\begin{array}{l}\text { Clear Choice } 100 \% \\
\underline{\text { Wind (PECO only) }}\end{array}$ & new wind & Green-e \\
\hline PA & $\begin{array}{l}\text { Energy Cooperative of } \\
\text { Pennsylvania }\end{array}$ & EcoChoice 100 & $\begin{array}{l}89 \% \text { landfill gas, } \\
10 \% \text { wind, } 1 \% \text { solar }\end{array}$ & Green-e \\
\hline PA & PECO Energy/Community Energy & PECO Wind & $\begin{array}{l}\text { 100-kWh blocks of } \\
\text { new wind }\end{array}$ & - \\
\hline RI & $\begin{array}{l}\text { Narragansett Electric / Clear Sky } \\
\text { Power }\end{array}$ & Clear Sky Home & $\begin{array}{l}100 \% \text { new } \\
\text { bioenergy }\end{array}$ & - \\
\hline RI & $\begin{array}{l}\text { Narragansett Electric / Community } \\
\text { Energy, Inc. }\end{array}$ & $\begin{array}{l}40 \% \text { NewWind } / 60 \% \\
\text { Small Hydro }\end{array}$ & $\begin{array}{l}60 \% \text { small hydro, } \\
40 \% \text { new wind }\end{array}$ & - \\
\hline RI & $\begin{array}{l}\text { Narragansett Electric / Community } \\
\text { Energy, Inc. }\end{array}$ & $\begin{array}{l}50 \% \text { NewWind } / 50 \% \\
\text { Small Hydro }\end{array}$ & $\begin{array}{l}50 \% \text { small hydro, } \\
50 \% \text { new wind }\end{array}$ & - \\
\hline RI & $\begin{array}{l}\text { Narragansett Electric / People's } \\
\text { Power \& Light }\end{array}$ & $\begin{array}{l}\text { New England } \\
\text { GreenStart RI } 50 \% \text { or } \\
\underline{100 \% \text { of usage }}\end{array}$ & $\begin{array}{l}70 \% \text { small hydro, } \\
17 \% \text { bioenergy, } \\
13 \% \text { wind and solar }\end{array}$ & - \\
\hline RI & $\begin{array}{l}\text { Narragansett Electric / Sterling } \\
\text { Planet }\end{array}$ & $\begin{array}{l}\text { Sterling Supreme } \\
\underline{100 \%}\end{array}$ & $\begin{array}{l}40 \% \text { small hydro, } \\
25 \% \text { biomass, } 25 \% \\
\text { new solar, } 10 \% \text { wind }\end{array}$ & $\begin{array}{l}\text { Environmental } \\
\text { Resources Trust }\end{array}$ \\
\hline $\mathrm{TX}$ & Commerce Energy & $\begin{array}{l}\text { Clear Choice All-In (12- } \\
\text { mo fixed rate) }\end{array}$ & $100 \%$ wind & Green-e \\
\hline $\mathrm{TX}$ & Commerce Energy & $\begin{array}{l}\text { Clear Choice All-In Plus } \\
\text { (24-mo fixed rate) }\end{array}$ & $100 \%$ wind & Green-e \\
\hline $\mathrm{TX}$ & First Choice Power & $\begin{array}{l}\text { Simply Better } \\
\text { Renewable }\end{array}$ & $100 \%$ renewable & - \\
\hline TX & Gexa Energy & Gexa Green & $100 \%$ renewable & - \\
\hline $\mathrm{TX}$ & Green Mountain Energy Company & $\begin{array}{l}\text { 100\% Wind: Month-to- } \\
\text { Month }\end{array}$ & wind & - \\
\hline $\mathrm{TX}$ & Green Mountain Energy Company & Pollution Free & $\begin{array}{l}10 \% \text { wind, } 90 \% \\
\text { hydro }\end{array}$ & - \\
\hline $\mathrm{TX}$ & Green Mountain Energy Company & $\begin{array}{l}\text { Pollution Free: Reliable } \\
\text { Rate }\end{array}$ & $\begin{array}{l}10 \% \text { wind, } 90 \% \\
\text { hydro }\end{array}$ & - \\
\hline $\mathrm{TX}$ & Reliant Energy & Renewable Plan & $100 \%$ wind & - \\
\hline TX & TXU Energy & TXU Energy $100 \%$ & $100 \%$ wind & - \\
\hline
\end{tabular}




\begin{tabular}{|l|l|l|l|c|}
\hline State & \multicolumn{1}{|c|}{ Company } & \multicolumn{1}{|c|}{ Product Name } & \multicolumn{1}{c|}{$\begin{array}{c}\text { Resource } \\
\text { Mix }\end{array}$} & \multicolumn{1}{c|}{ Certification } \\
\hline TX & TXU Energy & EarthWise & & - \\
\hline VA & $\underline{\text { PEPCO Energy Services (7) }}$ & $\begin{array}{l}\text { TXU Energy 100\% } \\
\text { EarthWise 18 }\end{array}$ & $10 \%$ wind & - \\
\hline VA & $\begin{array}{l}\text { PEPCO Energy Services (7) } \\
\text { of usage }\end{array}$ & $\begin{array}{l}\text { NewWind Energy 100\% } \\
\text { of usage }\end{array}$ & new wind & - \\
\hline
\end{tabular}

Source: National Renewable Energy Laboratory

* The Massachusetts Technology Collaborative's Clean Energy Choice (CEC) program provides local matching grants for clean energy projects for residents who make a voluntary offering.

${ }^{1}$ As product prices fluctuate, please contact the listed marketers to get accurate price quotes for products.

${ }^{2}$ New is defined as operating or repowered after January 1, 1997 based on the Green-e standard.

${ }^{3}$ Offered in PEPCO service territory.

${ }_{5}^{4}$ Product offered in Baltimore Gas and Electric and PEPCO service territories.

${ }^{5}$ Products are only available in the National Grid service territory.

${ }^{6}$ Offered in Niagara Mohawk and NYSEG service territories.

${ }^{7}$ Products are available in Dominion Virginia Power service territory. 


\section{Appendix G}

Table G-1. Renewable Energy Certificate Retail Products, October 2007

\begin{tabular}{|c|c|c|c|c|c|}
\hline $\begin{array}{l}\text { Certificate } \\
\text { Marketer }\end{array}$ & Product Name & $\begin{array}{l}\text { Renewable } \\
\text { Resources }\end{array}$ & $\begin{array}{l}\text { Location of } \\
\text { Renewable } \\
\text { Resources }\end{array}$ & $\begin{array}{l}\text { Residential } \\
\text { Price } \\
\text { Premiums* }\end{array}$ & Certification \\
\hline 3Degrees & $\begin{array}{l}\text { Renewable } \\
\text { Energy } \\
\text { Certificates } \\
\end{array}$ & $100 \%$ new wind & Nationwide & $2.0 \$ / \mathrm{kWh}$ & Green-e \\
\hline$\frac{3 \text { Phases }}{\text { Renewables }}$ & $\underline{\text { Green }}$ Certificates & $\begin{array}{l}100 \% \text { biomass, } \\
\text { geothermal, } \\
\text { hydro, solar, } \\
\text { wind }\end{array}$ & Nationwide & $1.2 థ / \mathrm{kWh}$ & Green-e \\
\hline $\begin{array}{l}\text { Bonneville } \\
\text { Environmental } \\
\text { Foundation } \\
\end{array}$ & $\begin{array}{l}\frac{\text { Denali Green }}{\text { Tags (Alaska }} \\
\underline{\text { only) }}\end{array}$ & $100 \%$ new wind & $\begin{array}{l}10 \% \text { Alaska, } 90 \% \\
\text { Nationwide }\end{array}$ & $2.0 \$ / \mathrm{kWh}$ & Green-e \\
\hline $\begin{array}{l}\text { Bonneville } \\
\text { Environmental } \\
\text { Foundation } \\
\end{array}$ & $\begin{array}{l}\text { Green Tags } \\
\text { Blend }\end{array}$ & $\begin{array}{l}90 \% \text { new wind, } \\
10 \% \text { new solar }\end{array}$ & Nationwide & $2.4 \phi / \mathrm{kWh}$ & Green-e \\
\hline $\begin{array}{l}\text { Bonneville } \\
\text { Environmental } \\
\text { Foundation }\end{array}$ & $\underline{\text { Green Tags }}$ & $100 \%$ new solar & Nationwide & $5.6 థ / \mathrm{kWh}$ & Green-e \\
\hline $\begin{array}{l}\text { Bonneville } \\
\text { Environmental } \\
\text { Foundation }\end{array}$ & Green Tags Wind & $100 \%$ wind & Nationwide & $2.0 \$ / \mathrm{kWh}$ & Green-e \\
\hline $\begin{array}{l}\text { Bonneville } \\
\text { Environmental } \\
\text { Foundation } \\
\end{array}$ & $\frac{\text { Zephyr Energy }}{\text { (Kansas Only) }}$ & $\begin{array}{l}50 \% \text { new low- } \\
\text { impact } \\
\text { hydropower }\end{array}$ & Mid-West, West & $2.0 \phi / \mathrm{kWh}$ & Green-e \\
\hline Carbonfund.org & Carbon Offsets & $\begin{array}{l}\text { wind, solar, } \\
\text { biomass, } \\
\text { efficiency, } \\
\text { reforestation }\end{array}$ & Nationwide & $\begin{array}{l}\$ 5.50 / \text { ton } \mathrm{CO} 2 \\
\text { (donation) }\end{array}$ & $\begin{array}{l}\text { Environmental } \\
\text { Resource } \\
\text { Trust** }\end{array}$ \\
\hline Carbonfund.org & MyGreenFuture & $\begin{array}{l}99 \% \text { new wind, } \\
1 \% \text { new solar }\end{array}$ & Nationwide & $0.5 \$ / \mathrm{kWh}$ & Green-e \\
\hline $\begin{array}{l}\text { Choose } \\
\text { Renewables }\end{array}$ & $\underline{\text { CleanWatts }}$ & $100 \%$ new wind & Nationwide & $1.7 థ / \mathrm{kWh}$ & Green-e \\
\hline Clean and Green & $\begin{array}{l}\text { Clean and Green } \\
\text { Membership }\end{array}$ & $100 \%$ new wind & Nationwide & $3.0 \phi / \mathrm{kWh}$ & Green-e \\
\hline $\begin{array}{l}\text { Community } \\
\text { Energy }\end{array}$ & NewWind Energy & $100 \%$ new wind & Nationwide & $2.5 \$ / \mathrm{kWh}$ & Green-e \\
\hline $\begin{array}{l}\text { Conservation } \\
\text { Services Group }\end{array}$ & ClimateSAVE & $\begin{array}{l}95 \% \text { new } \\
\text { wind/hydro, 5\% } \\
\text { new solar }\end{array}$ & $\begin{array}{l}\text { Kansas, New } \\
\text { England } \\
\text { (wind/hydro), } \\
\text { New York (solar) }\end{array}$ & $\begin{array}{l}1.65 \phi / \mathrm{kWh}- \\
1.75 \phi / \mathrm{kWh}\end{array}$ & Green-e \\
\hline $\begin{array}{l}\text { Maine Interfaith } \\
\text { Power \& Light }\end{array}$ & 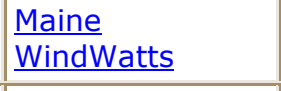 & $100 \%$ new wind & Maine & $2.0 \$ / \mathrm{kWh}$ & - \\
\hline $\begin{array}{l}\text { Maine Interfaith } \\
\text { Power \& } \\
\text { Light/BEF } \\
\end{array}$ & $\begin{array}{l}\text { Green Tags } \\
\text { (supplied by } \\
\underline{\text { BEF) }}\end{array}$ & $\begin{array}{l}99 \% \text { new wind, } \\
1 \% \text { new solar }\end{array}$ & Nationwide & $2.0 \$ / \mathrm{kWh}$ & - \\
\hline $\begin{array}{l}\text { Mass Energy } \\
\text { Consumers }\end{array}$ & $\begin{array}{l}\text { New England } \\
\text { Wind Fund }\end{array}$ & $100 \%$ new wind & New England & $\begin{array}{l}\sim 5.0 \$ / \mathrm{kWh} \\
\text { (donation) }\end{array}$ & - \\
\hline
\end{tabular}




\begin{tabular}{|c|c|c|c|c|c|}
\hline Alliance & & & & & \\
\hline NativeEnergy & Coo/Driver & $\begin{array}{l}\text { New wind and } \\
\text { biogas }\end{array}$ & Nationwide & $\begin{array}{l}\sim 1.2 \$ / \mathrm{kWh}, \\
\$ 12 \text { per ton } \\
\text { CO2 avoided }\end{array}$ & $* * *$ \\
\hline NativeEnergy & Coo/Watts & $100 \%$ new wind & Nationwide & $0.8 థ / \mathrm{kWh}$ & Green-e \\
\hline NativeEnergy & $\underline{\text { WindBuilders }}$ & $100 \%$ new wind & $\begin{array}{l}\text { South Dakota, } \\
\text { North Dakota }\end{array}$ & $\begin{array}{l}\sim 1.2 \$ / \mathrm{kWh}, \\
\$ 12 \text { per ton of } \\
\text { CO2 avoided }\end{array}$ & $* * *$ \\
\hline NativeEnergy & $\begin{array}{l}\text { Remooable } \\
\text { Energy }\end{array}$ & $\begin{array}{l}100 \% \text { new } \\
\text { biogas }\end{array}$ & Pennsylvania & $\begin{array}{l}0.8 \phi / \mathrm{kWh}- \\
1.0 \phi / \mathrm{kWh}\end{array}$ & $* * *$ \\
\hline $\begin{array}{l}\text { Pacific Gas \& } \\
\text { Electric }\end{array}$ & Climate Smart & $\begin{array}{l}\text { various local } \\
\text { projects }\end{array}$ & California & $\$ 4.31 / \mathrm{mo}$ & - \\
\hline $\begin{array}{l}\text { Premier Energy } \\
\text { Marketing }\end{array}$ & $\begin{array}{l}\text { Renewable } \\
\text { Energy Credits }\end{array}$ & $100 \%$ wind & Nationwide & $\begin{array}{l}1.5 \phi / \mathrm{kWh}- \\
2.0 \phi / \mathrm{kWh}\end{array}$ & Green-e \\
\hline $\begin{array}{l}\text { Renewable } \\
\text { Choice Energy }\end{array}$ & American Wind & $100 \%$ new wind & Nationwide & $2.5 \$ / \mathrm{kWh}$ & Green-e \\
\hline$\frac{\text { Renewable }}{\text { Ventures }}$ & $\begin{array}{l}\text { PVUSA Solar } \\
\text { Green } \\
\text { Certificates }\end{array}$ & $100 \%$ solar & California & $3.3 \phi / \mathrm{kWh}$ & Green-e \\
\hline SKY energy, Inc. & $\begin{array}{l}\frac{\text { Wind-e }}{\text { Renewable }} \\
\text { Energy }\end{array}$ & $100 \%$ new wind & Nationwide & $2.4 థ / \mathrm{kWh}$ & Green-e \\
\hline Sterling Planet & $\begin{array}{l}\text { Sterling Green } \\
\text { Energy }\end{array}$ & $\begin{array}{l}100 \% \text { new wind, } \\
\text { hydro, } \\
\text { geothermal, } \\
\text { methane, or } \\
\text { bioenergy }\end{array}$ & Nationwide & $1.5 \phi / \mathrm{kWh}$ & - \\
\hline Sterling Planet & Sterling Solar & $100 \%$ new solar & Nationwide & $7.5 \phi / \mathrm{kWh}$ & - \\
\hline TerraPass Inc. & TerraPass & $\begin{array}{l}\text { Various } \\
\text { (including } \\
\text { efficiency and } \\
\text { CO2 offsets) }\end{array}$ & Nationwide & $\sim \$ 10 /$ ton CO2 & - \\
\hline $\begin{array}{l}\text { Waverly Light \& } \\
\text { Power }\end{array}$ & $\begin{array}{l}\text { Iowa Energy } \\
\text { Tags }\end{array}$ & $100 \%$ wind & Iowa & $2.0 \$ / \mathrm{kWh}$ & - \\
\hline WindCurrent & $\begin{array}{l}\text { Chesapeake } \\
\text { Windcurrent }\end{array}$ & $100 \%$ new wind & $\begin{array}{l}\text { Mid-Atlantic } \\
\text { States }\end{array}$ & $2.5 \$ / \mathrm{kWh}$ & Green-e \\
\hline
\end{tabular}

Notes:

*Product prices are updated as of July 2006. Premium may also apply to small commercial customers. Large users may be able to negotiate price premiums.

${ }^{* *}$ Product is sourced from Green-e and ERT-certified RECs. ERT also certifies the entire product portfolio.

${ }^{* * *}$ The Climate Neutral Network certifies the methodology used to calculate the $\mathrm{CO}_{2}$ emissions offset.

NA = Not applicable.

Source: National Renewable Energy Laboratory 


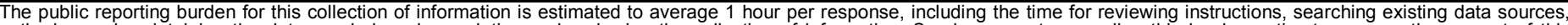

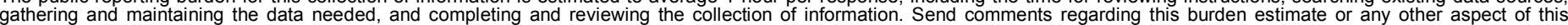

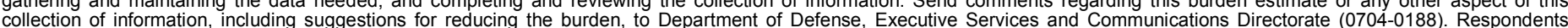

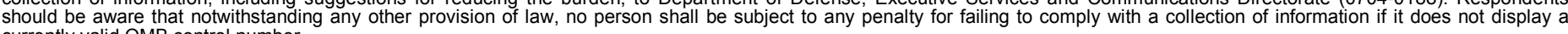

PLEASE DO NOT RETURN YOUR FORM TO THE ABOVE ORGANIZATION.

\begin{tabular}{l|l|l|} 
1. REPORT DATE $(D D-M M-Y Y Y Y)$ & 2. REPORT TYPE & 3. DATES COVERED (FrOm - TO)
\end{tabular}

December 2007

Technical Report

4. TITLE AND SUBTITLE

Green Power Marketing in the United States: A Status Report

(Tenth Edition)

5a. CONTRACT NUMBER

DE-AC36-99-G010337

5b. GRANT NUMBER

5c. PROGRAM ELEMENT NUMBER

6. AUTHOR(S)

Lori Bird, Leila Dagher, and Blair Swezey

5d. PROJECT NUMBER

NREL/TP-670-42502

5e. TASK NUMBER

IGST.7330

5f. WORK UNIT NUMBER
7. PERFORMING ORGANIZATION NAME(S) AND ADDRESS(ES)

National Renewable Energy Laboratory

1617 Cole Blvd.

Golden, CO 80401-3393
8. PERFORMING ORGANIZATION REPORT NUMBER

NREL/TP-670-42502

9. SPONSORING/MONITORING AGENCY NAME(S) AND ADDRESS(ES)

10. SPONSOR/MONITOR'S ACRONYM(S) NREL

11. SPONSORING/MONITORING AGENCY REPORT NUMBER

12. DISTRIBUTION AVAILABILITY STATEMENT

National Technical Information Service

U.S. Department of Commerce

5285 Port Royal Road

Springfield, VA 22161

\section{SUPPLEMENTARY NOTES}

\section{ABSTRACT (Maximum 200 Words)}

This report documents green power marketing activities and trends in the United States, focusing on consumer decisions to purchase electricity supplied from renewable energy sources and how this choice represents a powerful market support mechanism for renewable energy development. The report presents aggregate green power sales data for all voluntary purchase markets across the United States. It also provides summary data on utility green pricing programs offered in regulated electricity markets, on green power marketing activity in competitive electricity markets, and green power sold to voluntary purchasers in the form of renewable energy certificates. It also includes a discussion of key market trends and issues.

\section{SUBJECT TERMS}

NREL; Green Power Marketing; utility green pricing programs; renewable portfolio standards; renewable electricity; carbon market interaction issues; customer interaction; REC markets; Blair Swezey; Lori Bird; Leila Dagher

\begin{tabular}{|c|c|c|}
\hline 16. SECURIT & CLASSIFICATI & N OF: \\
\hline $\begin{array}{l}\text { a. REPORT } \\
\text { Unclassified }\end{array}$ & $\begin{array}{l}\text { b. ABSTRACT } \\
\text { Unclassified }\end{array}$ & $\begin{array}{l}\text { c. THIS PAGE } \\
\text { Unclassified }\end{array}$ \\
\hline
\end{tabular}

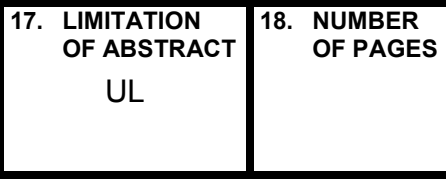

19a. NAME OF RESPONSIBLE PERSON

19b. TELEPHONE NUMBER (Include area code) 